\title{
Economic Feasibility Analysis of Distributed Electric Power Generation Based Upon the Natural Gas-Fired Fuel Cell
}

Final Report

Work Performed Under Cooperative Agreement No.: DE-FC21-92MC29227

\author{
For \\ U.S. Department of Energy \\ Office of Fossil Energy \\ Morgantown Energy Technology Center \\ P.O. Box 880 \\ Morgantown, West Virginia 26507-0880 \\ By
The Southern California Gas Company \\ Research Department \\ P. O. Box 3249 \\ Los Angeles, California 90051-1249
}

March 1994 


\begin{abstract}
The final report on the Economic Feasibility Analysis of Distributed Electric Power Generation Based Upon the Natural Gas-Fired Fuel Cell provides a summary of the results of the Cost of Ownership Model and the circumstances under which a distributed fuel cell is economically viable. The analysis is based on a series of micro computer models estimate the capital and operations cost of a fuel cell central utility plant configuration. Using a survey of thermal and electrical demand profiles, the study defines a series of energy user classes. The energy user class demand requirements are entered into the central utility plant model to define the required size the fuel cell capacity and all supporting equipment. The central plant model includes provisions that enables the analyst to select optional plant features that are most appropriate to a fuel cell application, and that are cost effective. The model permits the choice of system features that would be suitable for a large condominium complex or a residential institution such as a hotel, boarding school or prison. Other applications are also practical, however such applications have a higher relative demand for thermal energy, a characteristic that is well-suited to a fuel cell application with its "free" source of hot water or steam. The analysis combines the capital and operating cost information from the preceding models into a Cost of Ownership Model to compute the plant capital and operating costs as a function of capacity and principal features and compares these estimates to the estimated operating cost of the same central plant configuration without a fuel cell.
\end{abstract}

Keywords: Fuel Cell, Economic Analysis, Thermal Energy Distribution. Distributed Power Generation, Feasibility Analysis, Central Plant Configuration, Cost of Ownership 


\section{DISCLAIMER}

This report was prepared as an account of work sponsored by an agency of the United States Government. Neither the United States Government nor any agency thereof, nor any of their employees, make any warranty, express or implied, or assumes any legal liability or responsibility for the accuracy, completeness, or usefulness of any information, apparatus, product, or process disclosed, or represents that its use would not infringe privately owned rights. Reference herein to any specific commercial product, process, or service by trade name, trademark, manufacturer, or otherwise does not necessarily constitute or imply its endorsement, recommendation, or favoring by the United States Government or any agency thereof. The views and opinions of authors expressed herein do not necessarily state or reflect those of the United States Government or any agency thereof. 


\section{DISCLAIMER}

Portions of this document may be illegible in electronic image products. Images are produced from the best available original document. 


\section{FOREWORD}

This report was prepared under cooperative agreement No. DE-FC2192MC29227, among the US Department of Energy, Fossil Energy, Morgantown Energy Technology Center, The Southern California Gas Company, The Brooklyn Union Gas Company and the Manes Associates, Incorporated. The participants are sponsoring an investigation by the Manes Associates, of the "Economic Feasibility of Distributed Electric Power Generation Based Upon the Natural GasFired Fuel Cell." 


\section{Table of Contents}

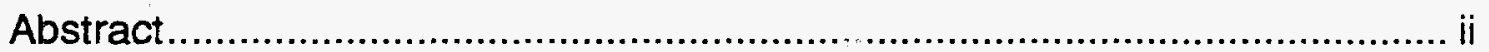

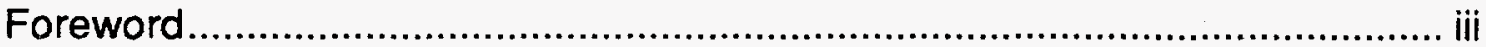

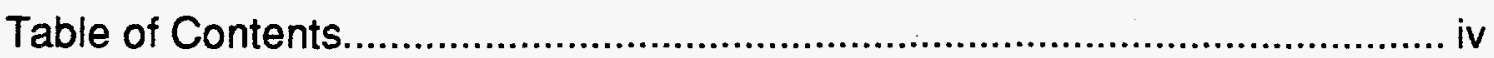

List of Figures ................................................................................... $\mathrm{V}$

List of Tables................................................................................ vi

List of Appendixes............................................................................. vii

Executive Overview ..................................................................... viii

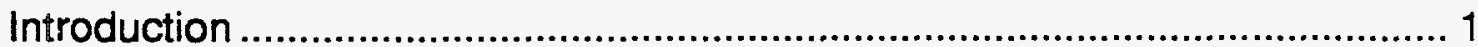

Economics of the Distributed Fuel Cells ................................................. 3

Ownership And Regulatory Considerations ...................................... 5

Market Trends and Implications for Fuel Cell Viability ........................ 12

Future of Capacity Ownership in the Electric Power Industry ............... 18

Analysis Structure .............................................................................. 19

Combined Use Energy Survey ..................................................... 20

Thermal Energy Distribution System Model ...................................... 21

Central Plant Utility Model.............................................................. 22

Capital Cost Model...................................................................... 23

Operations Model........................................................................ 23

Cost Of Ownership Model ................................................................... 24

Capital Investment Assumptions .................................................. 25

Economic Case Scenarios ..................................................................... 27 
List of Tables

Table 1 - Typical Economics for Fuel Cell Applications .................................. 4

Table 2 - Fuel Cell Emissions Compared to Combustion Turbine Emissions.. 8 


\section{List of Figures}

Figure 1 - Elements of an Economic Feasibility Analysis of Fuel Cell Based

Power Generation ................................................................................. 19 
List of Appendixes

Appendix A - Cost of Ownership User's Guide

Appendix B - Review of Regulatory Issues

Appendix C - Model Scenario Detail

Appendix D - Cost of Ownership Model 


\section{Executive Overview}

The economics of distributed fuel cell applications are influenced by existing technology, electric power regulation and market circumstances. In selected applications the currently available cell can offer an economical alternative to the purchase of power and thermal energy from the local utility. The fuel cell has a substantial advantage over other generation technologies in its ability to match the demand of an application to the fixed capacity of the fuel cell. The fuel cell has excellent part power performance. This permits operation during low demand periods without increasing operating and maintenance or energy costs per $\mathrm{kW}$ hour. However, applications with very low effective capacity cannot sustain high capital costs of a fuel cell system that operates as little $35 \%$ of the time. Retail operations, business offices, and entertainment facilities are examples of this low operating percentage.

Thus, combining applications to share the energy generated from a fuel cell is economically promising, but requires modification or elimination of current regulatory barriers concerning sale or distribution of electric power from a nonutility. In California, the California Public Utilities Commission prohibits the sharing of capacity by two or more owners. In the context of the National Energy Policy Act of 1992, the national trend is toward open access to the transmission grid and all source's power production and distribution. If current tends continue and given time, the state regulation commission will adopt FERC rulings on the transportation of retail electric power from non-utility generation sources.

Existing utility regulations constrain an important group of possible owners or users from considering a fuel cell investment. Since they are reluctant to accept competing power sources from within their service territory, local utilities rigorously control access to the utility owned electric power transmission grid. Barriers range from legislation restricting wheeling of power to third parties to fees for back up service. These barriers to the fuel cell are significant deterrents to the economic viability of distributed fuel cell ownership. In California and several other states, the fuel cell owner is considered a regulated utility if they sell electricity to more than one customer. The only exception from this restriction is an application without electric power meters. For example, the owner of an office building or a shopping center could rent space with "utilities included."

Incorporating the fuel cell into a larger plant system is the best method for maximizing its economics. Central plant configurations that use a hydronic system for space conditioning are most likely to fully use the energy conversion capacity of the fuel cell. Combining an air-conditioning system based on an 
absorption chiller with the hydronic distribution system improves the systems economics. The economy-of-scale of larger absorption systems, combined with their lower operating costs, can make absorption chilling the most economical space conditioning system and improve the economics of the distributed fuel cell application. When sized to meet the peak electrical demand of an applicaticn, the fuel cell-based central utility plant systems have a lower cost of ownership than the purchased power alternate. Distributed fuel cell applications have a lower cost of ownership in applications with an effective capacity as low as $75 \%$ of nameplate.

The analysis results indicate that distributed energy plant configurations require a fuel cell which can be sized to the systems configuration power requirements. However, the currently available commercial fuel cell is manufactured in one size with inflexible physical packaging. The results of this analysis indicate that a modular fuel cell design that expands over a range of 200 to $2,000 \mathrm{~kW}$ will have substantially larger market potential than the current fixed $200 \mathrm{~kW}$ commercial unit. Industrial boilers are effectively available in any capacity despite the relatively lower capital cost and smaller "penalty" of unused capacity. Distributed fuel cell economics will not be viable without the ability to size the fuel cell capacity to the distributed plant configuration power requirements.

Distributed fuel cell economics are a captive of market circumstances that restrict competition and construct barriers to market entry. The economic viability of the distributed fuel cell depends on eliminating these restrictions. Fuel cell technology has not achieved commercial status. Commercial application of the fuel cell is a promise for the future. Fulfillment of the promise will depend on changing the market to allow its entry and enable it to reach commercial maturity. 
Introduction

The development of the fuel cell first occurred in the 1960's, with the operation of the hydrogen-oxygen power cell used on manned orbital and lunar missions. Since then, the technology has advanced to the verge of commercial deployment. There have been important improvements in the technology. Fuel diversity, resistance to contamination and energy conversion efficiency have all been dramatically improved over the early models that provided astronauts with hot water and electric power. Despite a concerted research and development effort and a public research investment measured in the hundreds of millions, the fuel cell industry is not much closer to commercial applications of the technology than at the time of the Gemini space capsule. Several factors contribute to Industry's failure to embrace fuel cell technology.

- High Capital Cost - The fuel cell cannot capture a significant fraction of the generation market with designs that cost from two to ten times the installed cost of competing technology of similar capacity. Higher cost per unit of capacity is compounded by a fundamental design approach that cannot readily matched to the application.

- Application Demand Swings - Daily and seasonal demand variations leave the smaller, non-utility, user with an investment that is used less than one third of the time. During the initial phases of commercial deployment when capital costs are high the lost opportunity costs of the unused capacity are prohibitive. Regulations that define a utility do not allow two or more users to share generating capacity. Building designers seldom balance the energy demands of an applications between gas and electricity because the first cost of gas-fired equipment is generally higher than Electric powered equipment to do the same job.

- Installation and Permits - Initial commercial installations incurred installation and permit cost almost equal to the cost of the fuel cell. Until the fuel cell industry produces standard installation configurations, the high installation costs may be repeated in each municipality, air basin or physically dissimilar location. 
- Systems Applications Deficiencies - The existing commercial fuel cell design is unique and does not conform to the National Electrical Code, ASME Boiler Code or any other recognized set of government or trade association standards. Each fuel cell application requires significant systems engineering to integrate it with other plant systems; which adds to the cost and difficulty of permitting and installing a fuel cell as compared to simply connecting to the electric power grid.

- Utility Energy Cost - The public utilities in the United States lead the world in providing the user with unlimited supplies of low cost, reliable energy without the need for a capital investment that may take years to recapture. The ready availability of seemingly endless supplies of inexpensive fuel and economic growth is largely responsible for this leadership.

The goal of this project is to determine scenarios in which energy generation by distributed fuel cells can be economically viable. This analysis considers the economics of placing existing natural gas fuel cells into standard plant systems configurations requiring less than 2 megawatts of electric power. The electric power demand profiles represent plant configurations in southern California. However, the electric power avoided costs use the demand charge schedules from both the Southern California Edison Corporation and the Consolidated Edison Company of New York. The initial analysis centers on the $200 \mathrm{KW}$ phosphoric acid fuel cell that is the only presently available commercial fuel cell. However, the structure of the model will accommodate a range of electrical capacities, and other fuel cell technologies.

The observations and conclusions in this report are based upon the results of modeling the economics of owning and operating a fuel cell in varying case scenarios. The study is based upon a model of possible fuel cell operations in various industrial applications, such as hotels, hospitals, and retail shopping centers, within the context of changing market and regulatory circumstances. Each distributed fuel cell application is different, with different systems configurations, electric and thermal energy demand profiles and ownership conditions and fuel cell economics are evaluated application by application. The analysis assumes that if the economics of a distributed fuel cell application satisfy the primary criteria for business investment, a positive net present value, then the distributed fuel cell application is economically viable. 


\section{Economics of the Distributed Fuel Cells}

As a new technology, fuel cells will be economically viable only if users of fuel cell systems are willing to pay for an installed system, and the fuel cell systems generate sufficient revenue stream to attract capital investment. The economic viability of fuel cell systems depends on the specifics of technology, economics and institutions; many of which are unknown, or simply have not been established. Therefore, a useful analysis must estimate how economic viability varies with changes in the key aspects of technology, economics and institutions, and identify the likely alternative scenarios for these aspects.

This economic analysis of distributed fuel cells uses a cost of ownership model that estimates the operating cost of a central utility plant employing a fuel cell and then compares the estimate to the same central plant configuration obtaining power and thermal energy from other sources. The analysis considers only existing technology and applications of fuel cells in plant systems requiring up to $2 \mathrm{MW}$ of electrical power. This range of plant systems covers most applications of the available commercial fuel cell.

The primary factors in the basic cost of ownership analysis are the projected electrical demand and the cost avoided by employing a fuel cell. The analysis considers secondary factors such as tax incentives, environmental incentives after estimating the operations cost of fuel cell system. In certain ownership situations, environmental and tax incentives increase the value of fuel cell ownership. Likewise, excessive backup electricity costs increase the cost of ownership. The various costs of ownership cases are a function of the ownership assumptions.

The analysis considers the size and frequency of the central utility plant's energy demands. The central utility plant model matches the fuel cell capacity and operating cost to the electric and thermal energy demand profiles of the application. Based on the fuel cell central utility plant configuration operating parameters, the cost of ownership model estimates the cost of the plant configuration with and without the fuel cell. The analysis does not attempt to design a fuel cell. Instead it uses standard fuel cell configurations to prepare an operating cost profile of a system including the fuel cell for a given operation period.

The primary study scenarios set the fuel cell's capacity to the peak demand of the central utility plant. If the central utility plant requires $1,200 \mathrm{~kW}$, the fuel cell in the design generates a peak electrical output of $1,200 \mathrm{~kW}$. In these situations, the fuel cell produces the peak energy required. The scenarios are included in a following section of the report and in Appendix C. The following table 
illustrates the typical economics for a fuel cell application for each energy user group.

Table 1

Economics for Typical Fuel Cell Applications

\begin{tabular}{lcccc}
\hline Energy User & Capacity & Life & Use Ratio & Net Present Value \\
\hline & & & & \\
Hotel & 200 & 20 & 0.52 & $\$ 41,463$ \\
Food Processing & 200 & 20 & 0.65 & $(\$ 109,946)$ \\
Office Building & 200 & 20 & 1.00 & $\$ 164,600$ \\
Office Building & 550 & 20 & 0.47 & $(\$ 745,013)$ \\
\hline
\end{tabular}

The economics of fuel cell ownership vary by the degree of in which the fuel cell is used. The fuel cell offers positive net present value and attractive internal rates of return if the full capacity of the fuel cell is employed, despite high initial capital cost. The office building and other daily use only applications are the least desirable application of the fuel cell because of their low (25 to 50 percent) utilization of the fuel cell's capacity.

The economics are feasible principally when the fuel cell capacity is sized to the peak demand. The economic improve when the fuel cell operates continuously at peak capacity. The ratio of electric capacity used to idle capacity is the key economic indicator. The economics of every case evaluated improves as the ratio of capacity used to idle capacity approaches unity.

The operations profile of a configuration of a distributed fuel cell should be designed to achieve continuous operation. This may be achieved by matching the size of the fuel cell to the central utility plant design, rather than the reverse. To accomplish the matching of capacity to demand, the fuel cell must be expandable to the level of peak demand. Another means of achieving a unity ratio between use and capacity ratio is to transfer any excess energy to secondary users.

The economics variation illustrated in Scenarios $B, C$ and $D$ vary with the size of the cell. The message to the Fuel Cell Industry is that tailoring the fuel cell capacity to the application demand may be the best way to achieve economic viability. This will allow a more rapid drop of the per unit drop in the price of the installed fuel cell. In the same manner that the boiler industry has turned custom installations into a commodity, the fuel cell industry should develop the 
capability to modularize the size of the fuel cell to fit the demands of the individual systems configuration.

These cases assume that the owner of the fuel cell is also the primary user of the electric and thermal energy produced. Because of the current regulations, the fuel cell owner may not sell or transmit excess power to a third party. The analysis model assumes this condition. However, the electric power generation market is evolving. Recent FERC rulings and the passage of the Energy Policy Act of 1992, indicate that ownership of power producing capacity may be less restricted in the future. These issues are discussed more fully in later sections of this paper and in Attachment B, Review of Regulatory Issues.

The opportunities for a fuel cell to market excess capacity increase as the electric power industry evolves from regulated to open competition. The current model should be modified in the future to incorporate a condition in which the fuel cell's capacity may be greater than the central utility plant peak demand. With this change, the analysis model could evaluate a range of fuel cell capacities greater than the peak electrical demand of the central utility plant. The fuel cell owner would have the option of using the excess capacity by expanding the central utility plant, transmitting the power to another location or selling it the local utility or to a third party.

As the electric power industry becomes increasing competitive and market driven, the fuel cell cost of ownership model assumptions must be adjusted in the future, the fuel cell performance and capital cost model should be refined to reflect practical small increments of capacity to better enable a match of demand to the equipment capabilities. In addition, a change should be made to the model input to allow multiple demands on the same fuel cell. This will permit the smoothing of the power sales scenarios to be consistent with forthcoming regulation changes on wheeling and retail power sales.

\section{Ownership And Regulatory Considerations}

The treatment of fuel cell revenues, expenses and incentives depended on the owners contractual and regulatory status The capital recovery period and the requisite returns on investment also vary by the class of owner, their industry and regulation.

The contractual arrangements between fuel cell users and the local utility for power sales, standby power, interconnection with the utility, and environmental obligations and the regulatory implications and limitations upon ownership scenarios are relevant to an understanding of current fuel cell economics. The opportunity for power sales could arise from user demands decreasing to below 
capacity, or from designing output purposely above peak user demand. Market availability for such sales as well as the costs incurred for participation in this market is of primary interest to the question of fuel cell economics.

Before 1978, the electricity market was considered a "natural monopoly." Large scale investor-owned utilities (IOU's) produced energy. The Public Utilities Regulatory Policy Act (PURPA 1978) challenged this traditional market monopoly by creating the Qualifying Facility (QF). QF's are independent power facilities that may be smaller than traditional utility plants, and use an alternative fuel source or conserve energy through the recovery of otherwise lost heat (cogeneration). The introduction of the Qualifying Facility was an attempt to capitalize on the various QF benefits to society and reduce reliance on fossil fuels. By diversifying the energy market and increasing competition, the long run objective of PURPA was to lower energy prices and increase load management flexibility and reliability.

Fuel Cell ownership scenarios can effect an independent power producer's (IPP) Qualifying Facility Status under PURPA. The sale of power from an IPP to more than two users, more than fifty percent utility ownership, and positioning the IPP in a "public trust" situation can all jeopardize QF status. An IPP violates the "public trust" condition when it serves more than two users (a co-generation facility selling power and thermal energy to a separate user with excess electricity being sold to the local electric utility has two users). The IPP is in a public trust situation when it is the only supplier of energy to the user (no utility backup). Hence the IPP is regulated as a public utility, subject to extensive regulation and redundancy standards. The IPP loses QF status.

Under PURPA, an independent power producer can offer excess power capacity to the utility under the terms of a Standard Offer Contract. Standard Offer 1, 2 and 3 contracts have been used to sell power from QFs on a short term basis since 1978. In 1993, the CPUC issued the Final Standard Offer (FSO4). Power sales contracts under FSO4 establish price offers based upon a utility's longrun marginal costs. These costs come from the respective utility's resource plan, including all cost effective potential generation additions (e.g., new plant construction, refurbishment, power purchases). The planned additions to capacity are Identifiable Deferrable Resources (IDR's). The IDR's planning estimates include estimated costs for permitting and environmental mitigation and are the utility's best estimate of the cost of new generation capacity.

Under the FSO4 auction methodology, QFs bid against the utility avoided cost benchmark computed from the projected capital and operating cost of the IDR. 1

'Administrative Law Judge Decision I.89-07-004, May 1993. 
Each potential bid is compared to a target price for an Identified Deferrable Resources (IDR) contained in the utilities Request for Bids. The IDR defines the cost of producing a $\mathrm{kWh}$ of electricity at a specific facility or by renewable technology. Essentially the IDR price per kW is the utility's bid in the FSO4 process. Parties offering electric power to the utilities are bidding against the IDR price. To be successful, the bid price must be at or below the IDR price.

The FSO4 bidding process is a second bid auction. This means that the price of electric power is set by the bid of the lowest losing bidder. Therefore, the economic analysis of potential alternatives is first to determine what potential scenarios fall below the IDR price. Bids below the IDR price receive further consideration. Those above the IDR price are eliminated.

Part of the bidding process involves estimating the impact of environmental subtracters. The bid submitted does not include subtracter for NOx, SOx, ROG PM10 and CO2. These emissions are assigned a dollar value based upon the estimated volume of the emission during generation of electric power. the dollar value is then subtracted from the electric power revenue. For example, a bid $\$ 0.06$ per kWh to sell power to a utility, the cost of the emissions would be subtracted from this number to determine the actual revenue. If the environmental subtracters are high, a bid could actually result in an economic loss. Therefore, an essential step in the economic analysis process is to estimate the impact of the environmental subtracters on the proposed bids.

The fuel cell would do very well under the FSO4 co-generation contracting scheme because it has the ability to be considered both a fossil and non-fossil QF. The primary source of fuel to date has been pipeline natural gas, but the fuel cell is capable of operating on any fuel with a methane content of $95 \%$ or more. 2 This means that the fuel cell could operate on biomass produced methane which is a renewable non-fossil resource. In essence, however the final bidding process is set up, the fuel cell will have the flexibility to adjust.

In the recently concluded Final Standard Offer 4 bidding process, a $1 \mathrm{MW}$ fuel cell would have successfully competed against power generated by a natural gas combustion turbine. ${ }^{3}$ The following table illustrates the impact of emission subtracters on the bid price. If the bid was accepted, the utility would subtract approximately $\$ 13,000$ per year from the price of $1 \mathrm{MW}$ year. Conversely, the turbine would pay a penalty of $\$ 295,540$ for the same level of electric power

${ }^{2}$ Fuel Cell Input/Output Model, Dan Kouwabunpat and Jeff Towson, May 1992.

${ }^{3}$ Standard Offer 4 (SO4) requires that the cost of emissions associated with generation of the electricity be subtracted from the bid price per $\mathrm{kWhr}$. The emission costs are estimated by multiplying the type and amount of emission by a set price per pound . 
generation. Translated to $\$$ per $\mathrm{kWhr}$, this means that a fuel cell cost per $\mathrm{kWhr}$ of $\$ 0.10$ per $\mathrm{kWhr}$ is the equivalent to a gas turbine cost of $\$ 0.0628$ per $\mathrm{kWhr}$ because of the emission subtracters and adders (the difference between -.002 and $.037 \$(\mathrm{kWhr})$.

Table 2

Fuel Cell Emissions Compared to Combustion Turbine Emissions

International $200 \mathrm{~kW}$ Fuel Cell Scaled to $1,000 \mathrm{~kW}$

\begin{tabular}{|c|c|c|c|c|c|c|c|c|}
\hline EMISSION & $\begin{array}{l}\text { Rate } \\
\text { lbs./hr }\end{array}$ & $\begin{array}{c}\text { Rate } \\
\text { Ibs/MeW }\end{array}$ & $\begin{array}{l}\text { Repower IDR } \\
\text { Ibs } M \text { MeW }\end{array}$ & $\begin{array}{l}\text { Annual Net } \\
\text { Emissions, lb }\end{array}$ & $\begin{array}{l}\text { Electrical } \\
\text { Emissions, lb }\end{array}$ & $\begin{array}{c}\text { Price } \\
1997 \$ / 1 b\end{array}$ & $\begin{array}{l}\text { Subtracter } \\
\text { \$MeWyr }\end{array}$ & $\begin{array}{l}\text { Subtracter } \\
\$ / k W h r\end{array}$ \\
\hline $\begin{array}{l}\text { NOx } \\
\text { SOx* } \\
\text { PM10 } \\
\text { ROG } \\
\text { Carbon }\end{array}$ & $\begin{array}{r}0.021 \\
0.000 \\
0.000 \\
0.038 \\
33\end{array}$ & $\begin{array}{r}0.105 \\
0.000 \\
0.000 \\
0.044 \\
167\end{array}$ & $\begin{array}{l}0.1023 \\
0.0047 \\
0.0398 \\
0.0284 \\
253.00\end{array}$ & $\begin{array}{r}21 \\
-37 \\
-315 \\
125 \\
-682,921\end{array}$ & $\begin{array}{r}20 \\
-37 \\
-315 \\
125 \\
-643,258\end{array}$ & $\begin{array}{r}20.140 \\
15.050 \\
4.360 \\
14.390 \\
0.021\end{array}$ & $\begin{array}{r}\$ 406 \\
(\$ 560) \\
(\$ 1,373) \\
\$ 1,799 \\
(\$ 13,508)\end{array}$ & $\begin{array}{r}0.000 \\
0.000 \\
0.000 \\
0.000 \\
-0.002 \\
\end{array}$ \\
\hline & \multicolumn{8}{|c|}{$\begin{array}{l}3 \text { MeW Combustion Turbine } \\
\text { Solar "Centaur" Turbine Model T-4700 Operated at 3633. kW }\end{array}$} \\
\hline $\begin{array}{l}\text { NOx } \\
\text { SOx* } \\
\text { PM10 } \\
\text { ROG } \\
\text { Carbon }\end{array}$ & $\begin{array}{l}7.250 \\
0.615 \\
0.103 \\
0.480 \\
1507\end{array}$ & $\begin{array}{r}1.996 \\
0.169 \\
0.028 \\
0.132 \\
415\end{array}$ & $\begin{array}{r}0.1023 \\
0.0047 \\
0.0398 \\
0.0284 \\
253.0000\end{array}$ & $\begin{array}{r}14,995 \\
1,303 \\
-90 \\
821 \\
1,280,831\end{array}$ & $\begin{array}{r}12,312 \\
1,070 \\
-74 \\
675 \\
1,051,671\end{array}$ & $\begin{array}{r}20.140 \\
15.050 \\
4.360 \\
14.390 \\
0.021\end{array}$ & $\begin{array}{r}\$ 247,965 \\
\$ 16,108 \\
(\$ 324) \\
\$ 9,706 \\
\$ 22,085 \\
\$ 295540\end{array}$ & $\begin{array}{l}0.031 \\
0.002 \\
0.000 \\
0.001 \\
0.003 \\
0.037\end{array}$ \\
\hline
\end{tabular}

Assuming a $200 \mathrm{~kW}$ fuel cell had been entered in the FSO4 bidding, the power sales auction bid scoring would be the following.

$$
1998 \$
$$

Energy Price, $\$ / \mathrm{kW}$
ERCC Price, $\$ / \mathrm{kW}$
Shortage Cost, $\$ / \mathrm{kW}$
Energy Score
ERCC Score
Shortage Score
SRA Score
Bid Score

2.54437207

356.988752

65.7817357

$\$ 0.02519$

$\$ 0.04463$

$\$ 0.01923$

$\$ 0.00002$

$\$ 0.08907$

The detail supporting this bid is included in Attachment C, Scenario F. The Energy Price in $4 / \mathrm{kW}$ is the first year value of the fuel required to drive the fuel cell. The Energy Related Capital Cost (ERCC) in $\$ / k W$ is the first year's value of 
the total levelized capital cost of the fuel cell. The Shortage Cost in $\$$ per $\mathrm{kW}$ are computed on the basis of the utility's view of the cost of replacing the capacity with a standard turbine. The shortage cost is computed solely on the characteristics of the IDR. The Energy Score is the energy price corrected for transmission losses and stated in dollars per kW hour. The ERCC Score is the difference between the energy price and the shortage cost, stated in $\$$ per $\mathrm{kW}$ $\mathrm{hr}$. The Shortage Score is the shortage cost adjusted for tax credits and variable operating costs, stated in \$ per kW hour. The SRA Score (System Reinforcement Adjustment) is intended to compensate the utility for additions to their transmission system to accommodate the additional energy purchase, stated in $\$$ per $\mathrm{kW}$ hour. The Bid Score is the sum of the score components used to compare the bids of the auction participants.

In the past, the cost of emissions has not been included in the cost of power generation. Power producers externalized these costs and deferred the cost of emissions abatement to others. The FSO4 process is a key instrument in linking the more emission-free emerging technologies with the utilities transmission monopoly. The FSO4 methodology offers the opportunity to capture environmental and fuel diversity benefits which the utilities are required to produce. The emissions adders or subtracters will be used to adjust the monthly payment by the utility to the Qualified Facility owner.

Standard Offers are not the only way to structure the QF generation procurement system. Many other states have experimented with competitive bidding programs to solicit QF power. One option considered and supported by the CPUC is "all-source bidding" where all potential suppliers may subscribe to provide capacity. Impeding the adoption of such a bidding system are two primary issues. First, is the absence of a functional way to quantify the value of non-price factors (environmental). Second, issues relating to transmission grid access ( generally termed "wheeling" ) are not resolved. There are several variations on the bidding systems; but generally the regulator sets the quantities and prices are a result of the cleared market, subject to ceilings defined by nonQF bulk power supply alternatives. This is more practical than a system that caps price but has no cap on quantity. Bidding programs are gaining widespread support and may be in implemented by the time fuel cell projects are on line.

Interconnection, Metering, and Grid Access

Fuel cell entry into the current QF market depends on the cost of interconnection into existing utility grid. While guaranteed utility interconnection, the QF's are financially responsible for the design, installation, operation, and maintenance of all equipment necessary for grid connection. In addition, the QF may also be 
responsible for system upgrades necessary for transmission and connection to the system. Furthermore, the QF must assume any responsibility for protection of equipment should disturbances in the system occur. In addition they are obligated for substantial demand payments to the utilities whether or not they call upon the utilities for emergency service. A few moments in unplanned outage could result in a months worth of demand charges. These significant financial liabilities have stymied many co-generation projects.

There are two ways to meter power sold back to the grid. Time of day metering is practical for QF's selling relatively more power at "on peak" times. Time of day meters record both the time and amount of power sold so that users selling power at "on peak" times can garner the highest price. Smaller facilities with less "on peak" capacity use average metering. Such facilities may actually benefit from the average metering method when they have high power sales at "off peak" times, as the time-weighted average price offers are higher than "off peak" prices. Both types of meters are measured monthly.

Use of utility owned transmission facilities is called "wheeling." The industry cannot function fairly or competitively until wheeling issues are resolved. The CPUC is currently in the process of establishing policy on transmission access consistent with a workable competitive market and all source bidding.

The commission also developed five goals:

1. Provide nondiscriminatory transmission access to non-utility power producers, to promote competitive generation;

2. Price transmission services at cost, to promote efficiency and preclude cross subsidization;

3. Ensure reliable service at the lowest possible cost;

4. Account for the environmental impacts of transmission facilities and their implications for the extent of possible future development;

5. Avoid a regulatory mechanism that would overburden parties or CPUC staff.

Two recent decisions made by the CPUC address wheeling and interconnection costs respectively. 4 The first decision asserts that interconnection of QF's outside of service area should be no different than any transaction within. The implication here is that utilities must provide transmission services at "cost" rates that have yet to be decided. The second decision addresses the payments for transmission line improvements. This decision provides that QF's are

4Decisions 88-04-0700, 91-04-040. 
responsible to upgrade those lines that are only beneficial to themselves. System wide benefits should be born by the consumer.

Quantifying the effects of such regulatory proceedings is difficult, since the effects of such regulatory changes have yet to manifest themselves. Though small QF's like the fuel cell may not engage in direct wheeling arrangements with other individual users, emerging regulations regarding such issues do affect fuel cell economic viability. As the industry moves away from traditional thinking about power monopolies, QF price offers and prices charged to consumers will come closer together. Current pricing scenarios reflect a considerable discrepancy here of at least 6 to 8 cents per kW. Presumably, the utility is charging this amount for transmission and load management. As the industry continues to adopt more liberal wheeling and interconnection policies, this anomaly should be reduced.

Willingness of a Utility to supply backup and supplementary power to cogenerators at a reasonable price is an issue of importance to the economic feasibility of distributed fuel cells. For example, for a large scale production facility with the fuel cell providing $75 \%$ of the power, the owner must contract with the utility for the remaining $25 \%$ of the energy, and for backup of the full $100 \%$ of demand power if the fuel cell fails. This is termed a demand charge. All industrial facilities must pay a demand charge in addition to the energy charge.

At the present time, the CPUC assures QF's of backup power at "reasonable rates." The definition of "reasonable rates" has been the subject of much controversy and litigation. The CPUC is attempting to clarify the "reasonable rates" criterion, but the concept is further complicated when different reliability levels and capacities are considered.

\section{Demand Charges}

Of interest to fuel cell owners is the connection or demand charges which the owner would pay if they call on the grid for energy in the case of fuel cell failure. Demand Charges are a function of the generating and transmission capacity and the capital investment of the investor owned utility and the period or time of the demand.

$$
D=f(\text { Capital Investment, generating capacity, period of use) }
$$

Normally, all industrial users incur a demand charge. The demand charge reserves a portion of the generating capacity for the industrial user. The level of the demand is defined in the generation agreement or the contract for electrical 
service. The estimated level of demand, expressed as kW's, is normally the lower of the company's estimate of the customer's peak demand or, in the case of standby demand, the nameplate capacity of the customer's generating facility. 5 A demand charge is calculated per kilowatt and per meter for each month in which electric service is required, divided into time related and non-time related components

The non-time related component of the demand charge is composed of a connection charge based upon the estimated peak demand, and the number of meters. The time related component of the demand charge is based upon the time of day or year in which the demand for electricity is made, usually Peak Demand and Off Peak demand periods of a day or winter or summer seasonal periods.

The demand charge is based on the rate schedule approved for the utility service territory and will vary by the utility. This study use rate schedules for demand charges from Southern California Edison and Consolidated Edison of New York; thus providing demand charge cost estimates for both west and east coast utilities. $^{6}$

Demand charges are relevant for every user identified in the User Demand Survey conduced as part of this analysis. Every user had a normal peak that was $30 \%$ higher than the average load, thus assuring that SCE will always collect summer peak demand charges. On average, the customer's demand will always be $50 \%$ of the previous twelve month's peak.

\section{Market Trends and Implications for Fuel Cell Viability}

The introduction of PURPA fostered the growth of many new co-generation projects. Fuel cell projects can currently capitalize on the many advantages of PURPA through the sale of excess electricity to utilities. As Qualifying Facilities, fuel cells may be able to generate revenue streams from electricity sales. Currently fuel cells can only sell power on an "as available basis". This is done through either signing a Standard Offer contract with one of the basin utilities. The emergence of long term, firm capacity contracts (FSO4) will provide fuel cells with a more secure, potentially profitable option for future power sales. The CPUC has begun to solidify the new QF market in hopes of encouraging new technologies such as the fuel cell. The Commission has forced utilities to provide backup power for new technologies at "reasonable rates" as well as assistance in interconnection planning and financing. Furthermore there seems

5 Schedule S, Standby PUC Sheet No. 16893-E, p. 2, June 7, 1992.

6 SCE Rate Schedule TOU-8, 1992 and Consolidated Edison Schedule, 1993 
to be a trend toward greater reliance on Qualifying Facilities such as the fuel cell in the future. Power sales to utilities can currently provide fuel cells with a substantial new revenue stream. Although economic viability of the fuel cell is dependent on many variables, legislation such as PURPA, in conjunction with strong CPUC support, increases the overall economic feasibility of fuel cells.

Probably the most important emerging regulation to fuel cell viability is expanded grid access and wheeling rights for IPP's and QF's. QF's like the fuel cell will be able to sell excess electricity in a more open market, reducing the utility's current monopoly. The current 9 cent price anomaly in the energy market will be significantly reduced. The CPUC will force electric utilities to set "fair" wheeling and interconnection rates.

In effect, the large demand charges are evidence that the utilities are understating the anticipated demand growth in order to retain control over the electricity utility grid. The lower demand projections translate into high "demand" charges because demand was not anticipated by the projections. The demand charge is a premium to compensate the utility for the unplanned use of its capacity. The lower power requirements growth rates also discourage the investment in additional capacity. With lower capacity, the utility remains in control for longer periods and artificially increases the price of energy.

As a further sign of CPUC commitment to the PURPA ideal, the CPUC has reinstated contracting for firm capacity in July 1993 and ordered the issuance of Final Standard Offer 4 request for bids by SCE, SDG\&E and PG\&E. This decision in combination with continuing work on all source bidding programs, interconnection and backup access, as well as reevaluations of the "avoided cost" assumptions reflect the continuing push to diversify power supply and ensure a place for QF's. All sources echo the understanding that the energy market will continue to diversify. Clean, efficient, new technologies like the fuel cell are welcomed.

In a recent decision, the Federal Energy Regulatory Commission (FERC) ruled that a Florida utility must wheel (Transmit) energy from an independent power producer at the same rate they charge themselves. In effect, the ruling approves retail wheeling at competitive rates. ${ }^{7}$ The commission's order gave Florida Power and Light (FP\&L) a 60 day period to negotiate the final price and nonprice terms and conditions of the network service, but told FP\&L it cannot base the rates on multiple charges for various power receipt and delivery points. In addition to embracing the idea of network service, the order also suggests that FERC has taken the first step towards imposing on the electric power industry

7Independent Power Report, p 16, November 5, 1993, FERC Docket No. ER93-465 
the comparability standard it adopted for the natural gas industry. The order emphasizes that the rates and non-rate terms and conditions under which the service is offered must be non-discriminatory and comparable to what FP\&L provides to other customers .

There are indications of power aggregation alliances being formed by non-utility organizations for the purpose of contracting with independent power sources and retailing the power. 8 AES Corporation of Arlington, Virginia announced that it is establishing a wholesale power marketing company to sell power form its own facilities as well as from other generators. LG\&E Energy is considering diversification into brokering and marketing power. At the American Cogeneration Association meeting in September 1993, speakers predicted that within five years electric power will be bought and sold and brokered as natural gas is now with generation rates established in the marketplace. If this trend continues, the "natural monopoly" assumed for utility electric power generation will be replaced by competition to produce the electric power from the most economic source. Access to the electric power distribution grid will be available to all power producers, regardless of ownership status.

The emergence of all source bidding will be a function of the development of CPUC plans to quantify non-price factors associated with QF's. These factors include such areas as emissions and environmental effects. When the CPUC has developed a workable plan for quantifying these values then all-source bidding may take place. Once these values are quantified then the QF status may drop away, as the designation will have lost its significance; PURPA goals will be met through a market system instead of regulation. Such simplification of the energy market, as long as non-price factors are accurately accounted for, will further ease the fuel cell's entry into the market.

Emerging regulations on grid access and "wheeling" will further enhance fuel cell viability. As deregulation of the industry continues, technologies such as the fuel cell will be more viable. The current price anomaly between offer prices and retail electricity will be significantly reduced as utility's monopolies are removed.

\section{Current Environmental Regulations and the Fuel Cell}

The fuel cell, because of its low relative emissions, has the potential to reap large environmental benefits. When compared to present co-generation technology, it offers reduced NOx, SOx, ROG, and PM10 emission levels. With present environmental legislation, however, these benefits are not being realized. One of the major shortfalls of current SCAQMD regulations is that they

8Independent Power Report, p 1, October 22, 1993 
offer no direct benefit to users operating equipment below emission threshold levels. Once a source's emissions are found to be at or below threshold levels, the source is exempted from any further environmental obligations. This approach negates the idea of creating capital and operating cost advantages for clean technologies by placing charges on pollution. For example, the most recent threshold limit set for new installations of boilers calls for NOx emissions of less than $30 \mathrm{ppm} .9$ The fuel cell operates with NOx emissions of less than 1 $\mathrm{ppm}$ without receiving a direct economic benefit.

If the difference between these levels could be translated to a monetary benefit for the fuel cell, it would be quite large. Based on a unchanging NOx emission offset price of $\$ 2500$ ( $10 \%$ lower than the lowest RECLAIM estimate), a discount rate of $10 \%$, and a period of 10 years, the present value of a base case fuel cell in terms of NOx emission payment avoidance under a system without thresholds (like RECLAIM) is well in excess of $\$ 64,000.10$ This translates to quite a capital cost advantage unrealized due to regulatory barriers.

The discrepancy between fuel cell emission levels and SCAQMD thresholds results mainly from two factors: 1) Monitoring of source emission levels becomes more costly as the size of the source decreases, and 2) the definition of Best Available Control Technology (BACT) under SCAQMD Rules and Regulations poses obstacles to new, clean technologies.

\section{Monitoring of Source Emissions}

The problem of monitoring is one which will most likely be remedied under the new RECLAIM program. Along with other enforcement measures, the District plans to implement systems of real time monitoring (CEMS), quarterly and year end accounting, and site inspection, to ensure accurate calculation of overall District emission levels. These measures, along with the market trading scheme under RECLAIM should allow for reductions in thresholds in the near future.

The present threshold is based on SCAQMD findings that $95 \%$ of presently operating equipment would be covered by the $30 \mathrm{ppm}$ NOx limit. To monitor the other $5 \%$ would require extensive marginal expenditures and was not viewed as economically reasonable. ${ }^{11}$ When a greater number of sources begin to fall under this threshold it will most likely be reduced to reflect emission levels achievable through new technology. Until incentives are offered to below

9SCAQMD Rule 1121.

${ }^{10}$ Calculated as $\mathrm{PV}=-\mathrm{Vi} \div(1+\mathrm{r})^{\mathrm{i}}$

11 Interview, Tim Little, 8-4-92. 
threshold users, however, the relative number of these users will be slow to increase.

There will have to be some form of incentive devised for technologies able to surpass emission reduction goals. This will stimulate research into new environmentally benign processes and will expedite the achievement of overall air quality attainment as proposed in the Clean Air Act. One such incentive program is the fuel diversity section of RECLAIM.

SCAQMD defines BACT as:

the most stringent emission limitation or control technique which: 1) has been achieved in practice, or 2) is contained in any state implementation plan approved by the EPA, or 3 ) is found technologically feasible and cost-effective compared to measures as listed in the AQMP or subsequent rules. 12

By this definition, until fuel cell technology or similar alternative energy technologies become commercially viable, relatively commonplace, and as cost effective as present control technology, they will not be used as standards. SCAQMD regulations do call for examination of emerging emission control technologies. Due to economic considerations, however, these technologies must be viewed as easily attainable and cost effective before they are utilized in the setting of emission thresholds.

In January, 1988 the SCAQMD Board adopted the Clean Fuels program. The program was designed to phase out the use of diesel, fuel oil, and solid fossil fuels, substituting methane, propane, and alternative clean fuels. The phase out process began in 1992 and is proposed to continue through 1997 when all stationary sources will operate with emission levels equivalent to or below the most efficient natural gas-fired processes. At this time, the phase-out program calls for extensive research into the area of alternative energy sources such as solar energy and fuel cells. Once the natural gas standard has been achieved, a new baseline standard will be chosen from emerging, reasonably expected technologies.

This policy seems consistent with the precedent set by diesel fuel in the early 1970's. At that time diesel was considered the new clean fuel and was used as a standard for many stationary and mobile source fuels. With recent advances in natural gas technology and increased awareness about the environment, however, the pollution levels associated with diesel technology are no longer

12SCAQMD Rule 1302. 
acceptable. This trend of adopting cleaner fuel standards as technology permits will most likely continue. This will obviously help fuel cells which seem to be one of the most feasible alternative energy solutions for the next two decades.

\section{Emerging Regulations and RECLAIM}

RECLAIM is a market approach to the control of pollution. It operates through the issuance of Emission Reduction Credits (ERC's) which can either be sold or used to meet a source's emission reduction requirements. This market approach would require new sources to purchase ERC's above the amount of their expected emissions (the present ratio is 1.2:1) in order to reduce overall emission levels in the basin. Similarly, sources which are either retired of altered to lower emission levels will receive ERC's for the purpose of sale or offset of future expansion. The two main questions facing the designers of the RECLAIM market are: 1) how to price the ERC's, and 2) how to trade them.

ERC pricing remains an area of great debate. Most experts agree, however, that ERC's will increase in price drastically over the next decade. In a recent ALJ opinion one finding of fact was, "as cheaper offsets are bought up, the price of offsets will quickly rise to reflect the buyer's marginal cost of emission control."13 With the SCAQMD's plan to raise emission control standards and general knowledge of the concept of diminishing returns vis-à-vis control expenditures, it is rather obvious that ERC prices will increase substantially.

Upward trends in emission offset trading prices have already been recorded. ${ }^{14}$ With trading volume rising substantially, the price of an annual one pound per day offset rose from $\$ 2150$ to $\$ 2600$. 15 SCAQMD predicted a continuation of this trend in its March 1992 draft of RECLAIM. The average price of NOx ERC's was expected to be $\$ 2800 /$ ton in 1994 with a potential price of $\$ 3300 /$ ton by 1997.16 Due to further research and valuation, these figures were revised in SCAQMD's June 1992 AQMP update which predicted NOX ERC's to increase in price from $\$ 4596 /$ ton in 1994 to $\$ 9783 /$ ton in 1997.17

There is no agreement among the experts as to the exact price ERCs will command in an open market. What can be assumed is that the price will start

13 ALJ 6-5-91, p. 103.

${ }^{14}$ Emission offsets have been traded since 1985 , but the market has been slow to develop.

RECLAIM offers a more defined system which will make trading a necessity for many new and existing sources.

${ }^{15} A E R^{*} X$ phone 6-18-92

16SCAQMD, RECLAIM, p. H-9.

17(1987 \$). SCAQMD, Socio-Economic impacts of the Proposed Amendments to the 1991 Air Quality Management Plan, June 1992. 
low and steadily increase to approximate the marginal cost of abatement. As emission regulations are tightened, which will occur until the District reaches attainment, the cost of abatement will increase more than geometrically. 18 In all likelihood, ERC prices will reflect this trend.

Future of Capacity Ownership in the Electric Power Industry

While too early to predict the complete restructuring of the electric power generating industry, there are indications of major realignments in the ownership of generating capacity. A Southern California Edison vice president stated that the company is looking at the possibility of spinning off their generation assets. PG\&E have already declared they would no longer be in the generation business. ${ }^{19}$

Both the Standard Offer 4 provisions, and FERC rulings on open transmission access indicate that future utility generation projects will be based on performance based pricing. Utilities will build new generation facilities on terms price competitive with other sources or purchase capacity from these sources. The most economic generating source will supply future capacity. The electric power generation will expand as dictated by market forces and not because of transmission access.

Scenario $F$, Attachment $C$, presents the case of a distributed fuel cell employed strictly as an electric power generator. This case could be an illustration of the economics of entering the electric power generation market as an investor. The scenario assumes operation of a $200 \mathrm{~kW}$ fuel cell continuously for a period of 20 years at 73 percent of capacity. The case also assumes that the industry will have installed at least 100 fuel cells of this capacity and thus the capital cost will have declined due to the learning process. Given these assumptions, the fuel cell installation has a positive net present value of $\$ 336,239$ and an internal rate of return of 21.24 percent. Both are strong enough to attract private investment to the purchase and operation of fuel cells for power generation, once this is permitted.

Additionally, Scenario $\mathrm{F}$ could be an illustration of the economics of using the fuel cell as a peaking capacity supplement by the local utility. The cost of electricity produced in this case is estimated to be $\$ 0.10095$ per $\mathrm{kWhr}$. This

${ }^{18}$ The law of diminishing returns dictates that the cost of removing 1 unit of pollution increases as the technology approaches $100 \%$ cleanliness. For example, to reduce emissions from $2 \%$ to $1 \%$ is far more costly than from $10 \%$ to $9 \%$.

19 California Energy Markets, October 15, 1993, p15. 
figure compares favorably to small scale generation capacities without the additional cost of transmission. By distributing fuel cells to "shave" peak demand requirements, utilities may defer the need for building additional generating capacity. In this context, the distributed fuel cell could be corisidered an element of demand side management .

\section{Analysis Structure}

The econcmic analysis structure consists of a survey of energy users, numeric models of an energy distribution system, capital cost of the hardware elements and an operations model. The models' output is combined with a series of

Figure 1

\section{Elements of An Economic Feasibility Analysis of Fuel Cell-Based Power Generation}

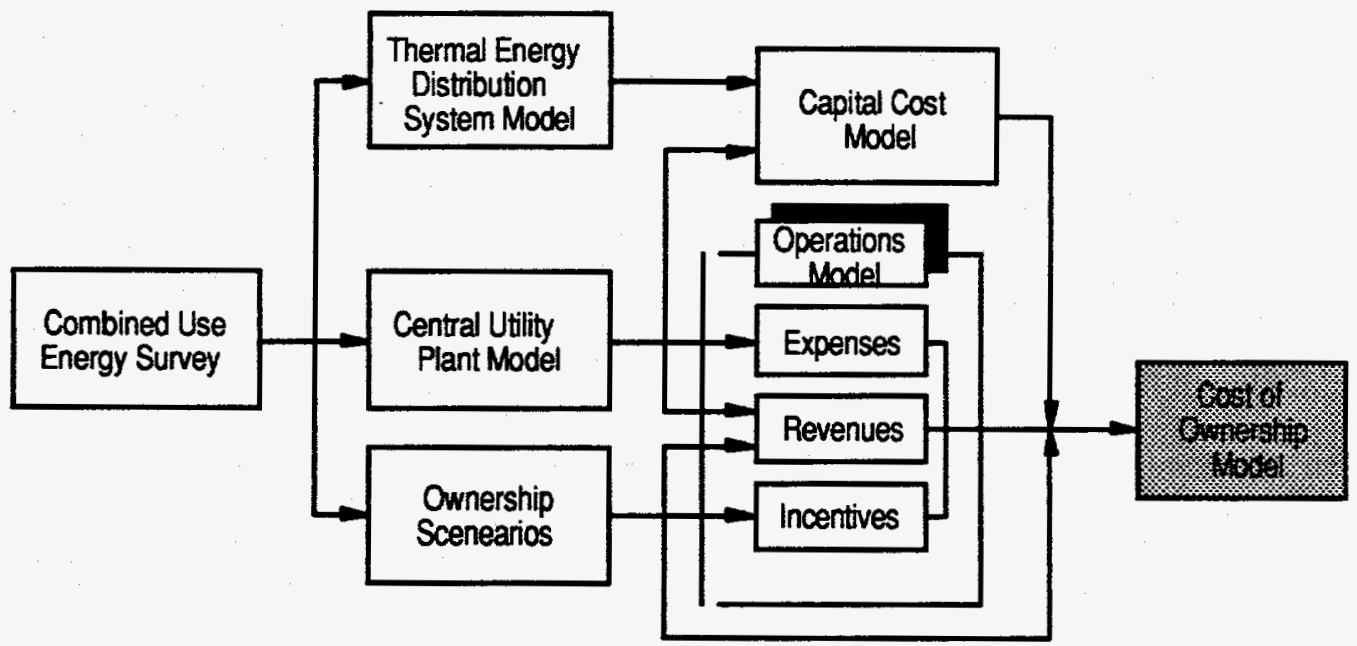

ownership scenarios to drive a model of the cost of ownership of a fuel cellbased power generation system. Figure 1 is a diagram of the relationship among the analysis model elements.

This structure is the basis for the ownership cases in this report. The cases conform to the assumptions of the demand profiles of the energy survey, the operational requirements of the central utility plant model, and the capital and operating costs of these model elements. Each case illustrates the economics of a distributed fuel cell in a unique business situation. The study conducted the economic analysis of each fuel cell systems case by varying the parameters of each major model elements and then processing the cost of ownership model. 


\section{Combined Use Energy Survey}

A survey of the extensive literature on energy consumption among a variety of user classes was conducted to establish the consumption rates and the relationship between consumption of thermal and electrical energy. The literature survey was supplemented with data on consumption history contributed by 15 industrial energy users in the Southern California area. The data fell into categories of demand profiles by industry and end-use that were nondimensionalized by peak use. The profiles were used to model the fuel cellbased utility plant that could satisfy the demand and a distribution system to deliver the thermal energy to the point of use.

This survey concentrated on commercial, industrial and residential users in the southern California Area. This area was chosen for its rigid air quality regulation with the potential economic benefit of avoided environmental insult and location that is convenient to the principal investigators. The climate of the area is temperate relative to the mid west and northern states. Space heating energy consumption in the region is low. This lower annual average heating load is largely offset by an extended cooling season. Consequently, the major conclusions of this report and subsequent project work are not compromised by the limited geographic survey area.

The survey found a number of commercial and industrial users whose energy demands are "ideally" matched to fuel cell output. The class of users that are able to realize the maximum economic benefits of the technology are from the hotel industry or large, multi-unit residential complexes. These groups have nearly equal demand for thermal and electrical energy because of their larger thermal demand for hot water for pool heating, sanitary, and food preparation applications.

The daily consumption profile characterizes the "residential" group. The peak consumption for electrical and thermal energy occurs early in the morning and late in the evening as the residents are either rising or preparing for bed. (See figure 3 and figure 4 for an example.) Day time institutions such as large retail stores or office buildings use $90 \%$ of their energy between 8 a.m. and 5 p.m. The supplementary demand profiles of these two groups suggest that an operating scenario that shares a single plant output could maximize the benefits for both users.

The consumption profiles depict an absolute difference between the instantaneous rate of energy consumption and it's integral. The mean daily thermal energy consumption of the hotel model is 410,000 BTU. The difference 
between the peak and the mean thermal energy could be stored in the form of hot water in an 1800 gallon tank. This will smooth the thermal demand on the fuel cell to the 410,000 mean and allow recapture of all the thermal energy produced.

Tighter controls on atmospheric emissions or favorable public utilities commission rulings on the definition of a "public utility" will expand the economic benefit of the technology. The threshold for the emerging RECLAIM program for marketable emission permits is too high for a fuel cell allowance. The current definition of a public utility includes those who sell energy to more than two customers. This would not allow the owner of a shopping mall or condominium complex to own a fuel cell and sell its output to the connecting utility and more than one customer.

\section{Thermal Energy Distribution System Model}

The report describes several types of thermal energy distribution systems that are suitable for the distribution of thermal energy to multiple uses. The primary conclusion drawn from the work is that a four-pipe, hydronic distribution system is most suitable for adaptation of the fuel cell based central utility plant.

The natural gas fuel cell produces electrical and thermal energy in an electrochemical reaction between natural gas fuel and oxygen from the air. The currently available phosphoric acid electrolyte cell produces about half of its energy in the form of hot $\left(\sim 150-175^{\circ} \mathrm{F}\right)$ water. The electrical energy conversion efficiency of the fuel cell is $44 \%$. Including the thermal energy produced, the efficiency is almost $90 \%$. The configuration either includes a system to distribute the thermal energy to the point of use or the thermal energy is rejected to the atmosphere.

A fin coil hydronic system is the most practical thermal distribution system for fuel cell applications. This system is the most prevalent industrial HIV design in use with large commercial and industrial users. Since the hydronic system works with either a fuel cell or boiler-chiller plant, the fuel cell application does not have an additional incremental cost. In addition, applications that now use a central utility plant will experience no change in the cost of their distribution system as a result of fuel cell installation. New designs of multi-unit residential applications that use forced air distribution system could realize significant avoided costs by installing a fuel cell based central plant. Space conditioning and potable water heating equipment for individual living units are replaced with relatively simple heat exchangers. The system does not require a forced air furnace, window air conditioners and a hot water heater. 


\section{Central Plant Utility Model}

The central plant utility model sizes a fuel cell for one of several user-chosen electrical demand profiles. The thermal energy produced is a dependent variable of the electric energy computed by a model of fuel cell performance and gas consumption. The model computes the thermal energy required for space conditioning and other uses to size an absorption chiller, boiler, thermal accumulator tank and system pumps. The central plant model matches the design capacity of the fuel cell to the application(s) demand; identifies and sizes central plant features to effectively utilize the energy produced; estimates the capacity of central plant elements as input to the capital cost model, and computes natural gas consumption and thermal energy produced as a function of fuel cell electrical load as input to the operations model.

Whenever possible, the central utility plant design exploits the "free energy" provided by fuel combustion. The central utility plant model design includes several characteristics of fuel cell-based plant design that enables the potential owner to capture the economic benefits of the higher efficiency energy conversion.

1. Fuel cell-based central utility plant systems if sized to meet the peak electrical demand of an application with duty cycles as low as $75 \%$, can have a lower cost of ownership than a purchased power alternate.

2. The variation in an application's demand for thermal energy is readily manageable. Excess thermal energy produced during off-peak hours and be saved and used to meet peak consumption demands. Thermal energy production considerations should not drive fuel cell sizing considerations.

3. The economic benefits, of $80 \%$ efficient energy conversion can be captured by considering the fuel cell as an element in a larger plant system that includes combined applications demand matching, thermal energy demand averaging and appliance load switching from electricity to thermal energy.

4. Potential applications that use hydronic system for space conditioning are most likely to fully employ the energy conversion capacity of the fuel cell. 
5. An absorption chiller in association with the hydronic distribution system processes the thermal energy from the fuel cell. The economy-of-scale of larger absorption systems, combined with their lower operating costs, can make absorption chilling the most economical space conditioning system and improve the economics of the fuel cell.

\section{Capital Cost Model}

The model computes the capital cost of the ancillary elements of the central utility plant design by scaling cost data from the R. S. Means Co.'s "Means Mechanical Cost Data, 1992" with a series of scaling relationships developed by multiple linear regression. The capacity or size of each element of the utility plant varies as a dependent variable of demand profile and user specified space conditioning loads. The capital cost of the fuel cell varies with a manufacturing learning expression. The initial value of fuel cell cost (the starting point on the learning curve) is one of the parameters of the feasibility analysis.

The capital cost model estimates the capital cost associated with the design capacity of the fuel cell defined by the central utility plant model; estimates the installation and start-up costs associated with the design capacity of the fuel cell defined by the central utility plant model; adjusts the estimated cost to allow for industry improvement in production and installation costs as the number of fuel cell applications increase; and provides a total capital cost value for each equipment scenario specified in the cost of ownership mode.

Fuel cell capital costs are a function of the fuel cell size and systems capacity. The capital cost model uses the systems capacity parameters defined in the Central Utility Plant model to estimate the cost of acquiring and installing the fuel cell system. The model estimates the procurement costs for the hardware based upon the size of the system and the number of systems in use. For the balance of plant equipment, the model estimates the per unit cost by multiplying the capacity of the unit by a cost factor. The cost factor is a least squared regression curve fit between the capacity of each hardware element and the published cost of the unit in 1992 dollars. Therefore, once the capacities of the balance of plant hardware are known, the model estimates the cost of the system.

\section{Operations Model}

The business operations model computes fuel cell operating expenses based upon gas price forecasts or an input parameter. The maintenance expenses 
include periodic fuel cell stack refurbishment and the purchase of back-up electric power and additional space heating boiler fuel while the cell is out of service.

The operations plant model computes fuel costs consistent with the application demand and seasonal price variations; computes the benefit of the avoided cost of purchasing electricity from the local utility at a price schedule that is consistent with the applications demand and daily and seasonal price variations; estimates the present and planned incentives to fuel cell ownership; provides the user with a choice of fuel cost growth forecasts to examine a variety of possible future operating scenarios and develops the required cost and revenue streams that are needed as input to the cost-of-ownership model.

The model imputes the revenue stream from the avoided cost of purchasing electric and thermal energy at rates appropriate to the ownership class, time of day and season. The Central Utility Plant Model computes the power and thermal energy production rates for the systems configuration. In addition, the revenue stream includes any associated investment credits, utility displacement credits or RECLAIM 20 permit sales. In some cases the enabling legislation to support these incentives do not yet exist. The operations model includes provisions to enable the prospective owner to account for this important source of revenue and public good-will.

\section{Cost Of Ownership Model}

The Cost of Ownership model combines the products of the capital cost model, ownership scenarios and the operations model revenue streams to compute the present value and total economic benefits of a distributed fuel cell. A user chooses the form of the output from a menu of cash flow curves, net present value or internal rate of return on investment options.

The analysis model contains default values for three primary classes of fuel cell application.

Class I - Large multi-story building with residential characteristics, such as hospitals, hotels and prisons.

${ }^{20}$ RECLAIM is the recently announced program of the South Coast Air Quality Management District to create a trading market for emission permits. The emissions of a fuel cell is below the most stringent limits proposed for the year 2010. A fuel cell owner should be able to sell all of their annual permit allowances on the open market. Similar programs have already been established at the federal level and will likely be emulated in other non-compliant areas of the country. 
Class II - Multi-unit Professional or retail applications characterized by 12 to 16 hours of operation per day such as office buildings, retail stores and shopping malls.

Class III- Industrial applications which consume energy at a relatively constant rate in three shift operations such as food processing plants and health clubs.

To provide flexibility in defining the ownership profile, the Cost of Ownership Model includes a fourth class of user.

Class IV - User defined application based upon the demand profiles in the Combined Use Survey or other source. Class IV can be any combination of the first three user classes, or a hypothetical application to "test" the economics of the application.

Class IV applies when the fuel cell application under study does not fit any one of the first three classes. The Class IV feature provides a method for the analyst to define the energy demand and systems capacities.

To operate the Cost of Ownership model, the user defines the class of energy user, and the type of ownership, taxable or non-taxable, and the sources of future gas and electric power prices. The Cost of Ownership produces an estimate of the cost of operation based upon the energy requirements of the Central Utility Plant Model for the selected user class. The cost of operation considers the thermal and electric demand profile for the class. The cost of back up electricity required considers the seasonal and time of day demand profiles as well as the appropriate utility demand charges.

The Cost of Ownership model estimates the benefits of the fuel cell installation by comparing the operations cost with a fuel cell to the cost of operation without the fuel cell for a given period of operation. When appropriate, the model includes the impact of taxes, tax credits and environmental offset credits.

To estimate the merit of the fuel cell investment, the model calculates the Net present value of the systems investment, the internal rate of return, the break even period in years, and the cost of the electricity produced in $\$$ per $\mathrm{kW}$ hour. The cost of electricity produced in $\$$ per $k W h r$ may be compared to similar figures for utility generated electricity.

\section{Capital Investment Assumptions}

The study considers the economic viability of a distributed fuel cell system to be the same as a major capital investment decision. To the potential owner, the 
distributed fuel cell investment must make business sense. In this context, if the net present value of the investment and revenue stream associated with a distributed fuel cell application over a given operational period is positive, the application is economically viable. If the net present value of the fuel cell investment is at least $\$ 1$ more than the alternative of purchasing electricity and thermal energy from other sources, then the distributed fuel cell application is economically viable, and therefore a good business decision.

However, the question of the cost of ownership over a time is a function of several factors and the assumption on which the distributed fuel cell application is based. The cost of ownership model provides an estimate for the capital cost, the environmental incentives, the operations and maintenance cost and the potential revenue of three classes of fuel cell application. Due to a shortage of statistics on fuel cell operations cost and reliability, structuring the economic analysis as a capital investment decision requires several basic assumptions.

First, the analysis assumes that there is a commercially available fuel cell and that the number of fuel cells in use will increase. This assumption is fundamental to the analysis because without a commercial supply of fuel cells that are reliable over an extended period of time, the technology will not become economically viable. Because of this assumption, the model estimates future manufacturing and installation costs by adjusting current hardware and installation costs using a learning curve.

Second, the analysis assumes that the fuel cell capacity can be adapted to the peak demand. The modifications in the central utility plant capacity based upon the demand profiles is based upon this critical assumption. Currently, the only commercial fuel cell is manufactured in one size, $200 \mathrm{~kW}$. The economic analysis assumes that as the demand increases, the one size only limitation will be over come.

Third, the model assumes that the manufacturer's specifications for operations and maintenance are achievable and realistic. The analysis accepts the maintenance periods represented by the fuel cell manufacturer and uses the reliability projections and the operational hours before major overhaul to structure the maintenance cost estimates.

Fourth, the analysis assumes that the barriers to permitting and licensing fuel cells will be eliminated as the market grows. Currently, the fuel cell installations in California are proving to be prohibitively expensive due to a protracted licensing and permitting cycle. The layers of local and state permit authority create an expensive review cycle that if continued, will add a significant cost burden to the ownership of a fuel cell. This assumption allows the economic 
analysis to consider the consecution of fuel cell system to be no more complex than any commercial alternative for electrical and thermal energy.

Fifth, the analysis assumes the fuel cell could be eligible for environmental credits in certain ownership scenarios. Considering the environmental benefits enhance the economics of the distributed fuel cell. The low emission characteristics of the fuel cell provide it with a significant competitive advantage over electricity produced by engines, turbines and central utility power plants.

\section{Economic Case Scenarios}

Model Scenarios A through E illustrate the economic potential for a fuel cell placed within varying plant systems contexts under changing operating assumption. The initial analysis steps through the three primary classes of fuel cell systems application, as defined by the Central Utility Plant Model, for by fuel cell capacity equal to, less than and greater than the peak demand under various ownership conditions.

Additionally, Scenario $F$ presents the economics of a $200 \mathrm{~kW}$ fuel cell as a Qualified Facility (QF) bid against the Final Standard Offer 4 Identified Deferrable Resources (IDR). This scenario provides information on how well a fuel cell would have faired in the recent $\mathrm{FSO} 4$ auction. In this case, the fuel cell would be able to sell power to the utility on a long term power sales agreement. The capital cost of the fuel cell installation is assumed to reflect at least 100 commercial installations at a learning rate of 90 percent.

The Model Input and Output Data Sheets for these Cases are included in Attachment C.

Scenario Set A - Continuous Operation at Full Capacity

This scenario compares the cost of ownership of a fuel cell operating continuously (Case 1) at full capacity with an office building operating only six days per week and 12 hours per day (Case 2). The comparison illustrates the benefit of operating the fuel cell continuously at capacity. The electric power generated in excess of demand could be wholesaled to a third party, or used in other ways to produced revenue to offset the operating costs.

Case 1: Office Building Fuel Cell operating continuously. Fuel Cell Capacity:

$200 \mathrm{~kW}$. Cooling Capacity57 tons 
Initial Price - \$per kW

Learning Rate- \%

Net Present Value of the Investment

Internal Rate of Return (\%)

Break Even in years

Cost of Electricity produced, \$ per kWhr

Average Cost of Electricity Purchase Avoided

Case 2: Office Building operating in the daytime.

Fuel Cell Capacity:

Cooling Capacity-

Initial Price - \$ per kW

Learning Rate- \%

Net Present Value of the Investment

Internal Rate of Return (\%)

Break Even in years

Cost of Electricity produced, \$ per kWhr

Average Cost of Electricity Purchase Avoided
$\$ 3,500$

$85 \%$

$\$ 164,600$

$13 \%$

8

$\$ 0.11213$

$\$ 0.07683$

Scenario Set B - Increasing Capacity and Constant Demand

This scenario includes five cases with increasing capacity and constant demand. which illustrate the effect of four different electric rate schedules: Southern California Edison TOU-8, TOU-GS and GS-2, in conjunction with Schedule S, Standby. The schedules maintain a relatively constant $\$$ per $\mathrm{kWh}$ despite large changes in the demand charges associated with the four schedules.

Case 1: Office Building -Continuous Operation

Fuel Cell Capacity:

$200 \mathrm{~kW}$

Cooling Capacity-

57 tons

Initial Price - \$ per kW

$\$ 3,500$

Learning Rate- \%

$85 \%$

Net Present Value of the Investment

Internal Rate of Return (\%)

Break Even in years

Cost of Electricity produced, \$ per kWhr

$\$ 164,600$

$13 \%$

8

Average Cost of Electricity Purchase Avoided

$\$ 0.11213$

$\$ 0.07684$

Case 2: Office Building -Continuous Operation

Fuel Cell Capacity:

$400 \mathrm{~kW}$

Cooling Capacity-

114 tons

Initial Price - \$ per kW

$\$ 3,500$

Learning Rate- \%

$85 \%$ 
Net Present Value of the Investment

Internal Rate of Return (\%)

Break Even in years

Cost of Electricity produced, \$ per kWhr

Average Cost of Electricity Purchase Avoided

$\$ 365,816$

$14 \%$

8

$\$ 0.11104$

$\$ 0.07683$

Case 3: Office Building - Continuous Operation

Fuel Cell Capacity:

$600 \mathrm{~kW}$

Cooling Capacity-

171 tons

Initial Price - \$ per kW

$\$ 3,500$

Learning Rate- \%

Net Present Value of the Investment

$85 \%$

Internal Rate of Return (\%)

Break Even in years

Cost of Electricity produced, \$ per kWhr

Average Cost of Electricity Purchase Avoided

$\$ 586.069$

$14 \%$

7

$\$ 0.11082$

$\$ 0.07735$

Case 4: Office Building-Continuous Operation

Fuel Cell Capacity:

Cooling Capacity-

Initial Price - \$ per kW

Learning Rate- \%

Net Present Value of the Investment

Internal Rate of Return (\%)

Break Even in years

Cost of Electricity produced, \$ per kWhr

Average Cost of Electricity Purchase Avoided

$1000 \mathrm{~kW}$

284 tons

$\$ 3,500$

$85 \%$

$\$ 1,001,192$

$14 \%$

7

$\$ 0.11053$

$\$ 0.07735$

Case 5: Office Building-Continuous Operation

Fuel Cell Capacity:

Cooling Capacity-

Initial Price - \$ per kW

$1500 \mathrm{~kW}$

427 tons

Learning Rate- $\%$

$\$ 3,500$

Net Present Value of the Investment

Internal Rate of Return (\%)

Break Even in years

Cost of Electricity produced, \$ per kWhr

$85 \%$

$\$ 1,520,095$

$14 \%$

7

Average Cost of Electricity Purchase Avoided

$\$ 0.11038$

$\$ 0.07735$

Scenario Set C - Large Office Building

For a Large Office Building operating 6 days a week, all cases are in the lowest energy cost and highest demand charge category. Any Air Conditioning 
requirement over 100 tons should be considered a candidate for change to absorption cooling. This can reduce electric demand by $70 \mathrm{~kW}$ per 100 tons; over 20,000 per year in this application.

Case 1: Office Building operating in the daytime.

Fuel Cell Capacity:

$550 \mathrm{~kW}$

Cooling Capacity-

34 tons

Initial Price - \$ per kW

$\$ 3,500$

Learning Rate- \%

$85 \%$

Net Present Value of the Investment

Internal Rate of Return (\%)

Break Even in years

$(\$ 745,013)$

$1 \%$

25

Cost of Electricity produced, \$ per kWhr

$\$ 0.17437$

Average Cost of Electricity Purchase Avoided

$\$ 0.11215$

Case 2: Office Building operating in the daytime.

Fuel Cell Capacity:

Cooling Capacity-

Initial Price - \$ per kW

Learning Rate- \%

Net Present Value of the Investment

Internal Rate of Return (\%)

Break Even in years

Cost of Electricity produced, \$ per kWhr

Average Cost of Electricity Purchase Avoided

$1100 \mathrm{~kW}$

67 tons

$\$ 3,500$

$85 \%$

$(\$ 1,437,717)$

$2 \%$

24

$\$ 0.17334$

$\$ 0.11215$

Case 3: Office Building operating in the daytime.

Fuel Cell Capacity:

$2000 \mathrm{~kW}$

Cooling Capacity-

122 tons

Initial Price - \$ per kW

$\$ 3,500$

Learning Rate- \%

$85 \%$

Net Present Value of the Investment

Internal Rate of Return (\%)

Break Even in years

Cost of Electricity produced, \$ per kWhr

Average Cost of Electricity Purchase Avoided

$(\$ 2,571,233)$

$2 \%$

24

$\$ 0.17288$

$\$ 0.11215$

Case 4: Office Building operating in the daytime.

Fuel Cell Capacity:

$3000 \mathrm{~kW}$

Cooling Capacity-

183 tons

Initial Price - \$ per kW

$\$ 3,500$

Learning Rate- \%

$85 \%$

Net Present Value of the Investment

$(\$ 3,830,696)$ 
Internal Rate of Return (\%) $\quad 2 \%$

Break Even in years

24

Cost of Electricity produced, \$ per kWhr

$\$ 0.17269$

Average Cost of Electricity Purchase Avoided

$\$ 0.11215$

Case 5: Office Building operating in the daytime.

Fuel Cell Capacity:

$4000 \mathrm{~kW}$

Cooling Capacity-

244 tons

Initial Price - \$ per kW

$\$ 3,500$

Learning Rate- \%

$85 \%$

Net Present Value of the Investment

Internal Rate of Return (\%)

Break Even in years

$2 \%$

23

Cost of Electricity produced, \$ per kWhr

$\$ 0.17259$

Average Cost of Electricity Purchase Avoided

$\$ 0.11215$

Scenario Set D - Food Processors Operating a Normal Shift.

The ratio of thermal to electric peak is held at user survey values: a ratio of .65 thermal to electric peak or greater. Even with improved utilization (greater than $65 \%$ ) the application will not pay off the fuel cell capital investment of $\$ 3500$ per $\mathrm{kW}$.

Case 1: Medium Industrial Users, Food Processing Fuel Cell Capacity:

Cooling Capacity-

$200 \mathrm{~kW}$

Net Present Value of the Investment

40 tons

Internal Rate of Return (\%)

$(\$ 109,946)$

Break Even in years

$6.11 \%$

14

Cost of Electricity produced, \$ per kWhr

Average Cost of Electricity Purchase Avoided

$\$ 0.13494$

$\$ 0.08473$

Case 2: Medium Industrial Users, Food Processing,

Fuel Cell Capacity:

Cooling Capacity-

$385 \mathrm{~kW}$

Net Present Value of the Investment

76 tons

Internal Rate of Return (\%)

Break Even in years

Cost of Electricity produced, \$ per kWhr

$(\$ 177,776$

$6.59 \%$

13

Average Cost of Electricity Purchase Avoided

$\$ 0.13356$

$\$ 0.08530$

Case 3: Medium Industrial Users, Food Processing, Fuel Cell Capacity:

$730 \mathrm{~kW}$ 
Cooling Capacity-

145 tons

Net Present Value of the Investment

$(\$ 284,251)$

Internal Rate of Return (\%)

Break Even in years

$6.98 \%$

Cost of Electricity produced, \$ per kWhr

Average Cost of Electricity Purchase Avoided

$\$ 0.13300$

$\$ 0.08530$

Case 4: Medium Industrial Users, Food Processing,

Fuel Cell Capacity:

$1460 \mathrm{~kW}$

Cooling Capacity-

290 tons

Net Present Value of the Investment

Internal Rate of Return (\%)

$(\$ 531,886)$

$7.11 \%$

Break Even in years

13

Cost of Electricity produced, \$ per kWhr

$\$ 0.13260$

Average Cost of Electricity Purchase Avoided

$\$ 0.08530$

Case 5: Medium Industrial Users, Food Processing,

Fuel Cell Capacity:

$2000 \mathrm{~kW}$

Cooling Capacity-

397 tons

Net Present Value of the Investment

$(\$ 715,068)$

Internal Rate of Return (\%)

$7.15 \%$

Break Even in years

13

Cost of Electricity produced, \$ per kWhr

$\$ 0.13250$

Average Cost of Electricity Purchase Avoided

$\$ 0.08530$

Scenario Set E - Small Hotel and Multi-unit Residential Hotels

Although a small hotel can utilize only $52 \%$ of the electric capacity of the fuel cell, hotels with installed capital cost from $\$ 1200$ to $\$ 2000$ per $\mathrm{kW}$ and assumed industrial learning of 90 to 92.45 percent may have a positive net present value. A small hotel application will return $38 \%$ on an investment of $\$ 1,000$ per $\mathrm{kW}$. The present value is larger than the initial cost of the fuel cell.

Case 1: Multi-unit Residential Hotels or Institutions

Fuel Cell Capacity:

Cooling Capacity-

$200 \mathrm{~kW}$

Initial Price - \$ per kW

20 tons

Learning Rate- \%

$\$ 1,200$

Net Present Value of the Investment

$92.45 \%$

Internal Rate of Return (\%)

$\$ 298,720$

Break Even in years

$28.44 \%$

Cost of Electricity produced, \$ per kWhr

4

Average Cost of Electricity Purchase Avoided

$\$ 0.08290$ 
Case 2: Multi-unit Residential Hotels or Institutions

Fuel Cell Capacity: $200 \mathrm{~kW}$

Cooling Capacity- 20 tons

Initial Price - $\$$ per kW $\$ 1,600$

Learning Rate- \% $\quad 92.45 \%$

Net Present Value of the Investment $\$ \$ 147,207$

Internal Rate of Return (\%)

Break Even in years

$15.79 \%$

7

Cost of Electricity produced, \$ per kWhr

$\$ 0.10799$

Average Cost of Electricity Purchase Avoided $\quad \$ 0.08290$

Case 3: Multi-unit Residential Hotels or Institutions

Fuel Cell Capacity:

Cooling Capacity-

Initial Price - \$ per kW

Learning Rate- \%

Net Present Value of the Investment

Internal Rate of Return (\%)

Break Even in years

Cost of Electricity produced, \$ per kWhr

Average Cost of Electricity Purchase Avoided

$200 \mathrm{~kW}$

20 tons

$\$ 2,000$

$92.45 \%$

$(\$ 4,306)$

$8.86 \%$

11

$\$ 0.12212$

$\$ 0.08290$

Case 4: Multi-unit Residential Hotels or Institutions

Fuel Cell Capacity:

Cooling Capacity-

$200 \mathrm{~kW}$

Initial Price - \$ per kW

20 tons

Learning Rate- \%

$\$ 2,000$

Net Present Value of the Investment

$90 \%$

Internal Rate of Return (\%)

Break Even in years

Cost of Electricity produced, \$ per kWhr

Average Cost of Electricity Purchase Avoided

$\$ 41,463$

$10.65 \%$

9

$\$ 0.11785$

$\$ 0.08290$

Scenario F - Qualified Facility

This scenario illustrates the economics of a fuel cell generating electric power as a Qualified Facility (QF) to be sold to the public utility under the provisions of Final Standard 4. This scenario also illustrates the possible economics of a fuel cell used by the utility as a method of meeting marginal peak demands without increasing plant generation capacity. The initial capital cost assumes that at least 100 units have been built and the industry learning curve is 90 percent. 
Case 1: Fuel Cell as a Qualified Facility

Fuel Cell Capacity:

$200 \mathrm{~kW}$

Cooling Capacity-

Initial Price - \$ per kW

Learning Rate- \%

Net Present Value of the Investment

Internal Rate of Return (\%)

Break Even in years

Cost of Electricity produced, \$ per kWhr

57 tons

$\$ 2147.24$

$90 \%$

$\$ 336,239$

$21.54 \%$

5

Average Cost of Electricity Purchase Avoided

$\$ 0.10095$

$\$ 0.08960$ 


\section{Cost of Ownership Model User's Guide}

Introduction

The cost of ownership model consists of three primary sections.

\section{Section One Section Two Section Three}

defines the parameters of the ownership case. presents the results of the ownership case. defines the detailed operations values and constants used in the analysis.

The model prints a separate page for each section. Together, the three pages document the economic case for the fuel cell application.

In Section One the user defines the fuel cell application by entering the primary capacity and demand parameters. The user selects key parameters on the class of energy user, sources of cost and rate data using option buttons .

Based upon the selected parameters, the ownership model prepares values for operations demands, costs and net benefits which are displayed in Sections Two and Three.

While the user is asked to defined certain key parameters, most of the values presented in the three sections come from one of the two sub models: The Capital Cost Model and the Operations Cost Model. These 'models estimate the electric and thermal demand, the capital cost and the operating costs for the central utility plant configuration selected. Any of the default values may be revised by overwriting the model derived value with a new value.

Initiating the Model

The Cost of Ownership model is in the Excel Workbook file Cell4.XLW.

To initiate the model, insert the model disk into the computer, open Excel and select Cell4.XLW.

The workbook file contains the cost of ownership model, the sub models and the macro statements required to link the model functions.

Workbook Contents

\begin{tabular}{l}
\hline Capital \\
Macro1 \\
Model \\
Operate
\end{tabular}


Select Model (The Cost of Ownership Model) to initiate the Cost of Ownership Model.

To refine the Capital (The Capital Cost Model) or Operations (Operations Cost Model) select one of the models and adjust the appropriate algorithm or expression.

It is not necessary to adjust values in these models to change the capacity or demand values. These data are entered in the User Input section of the Cost of Ownership Model. Adjust the values in the sub models only when the primary model structures are to be revised.

\section{Section One - USER INPUT PARAMETERS}

The Model User Input Parameters Sheet is depicted on the following page. Enter data into the model as described in the following steps.

Step

Description

1. Select the Fuel Cell Energy User Class from the Model Options. The Model contains three classes of fuel cell application: Class I- Multi-Unit Residential or Hotel; Class II- Medium Sized Industrial ; and Class IIIOffice Building.

By designating Class IV, the user may define a unique or hybrid fuel cell application. For example, use Class IV when evaluating the economics of scenarios in which the fuel cell output capacity is not equal to the peak electrical demand of the application. The demand profiles for Class IV must be entered according to the model's instructions.

For the three primary energy user classes, the model defaults to electrical and thermal demand profiles and operations characteristics information from the three sub models. These values are displayed at the top of the page. The model also displays the estimated capital cost for the class and capacity of the plant defined. Any of the model's operations or capital cost data elements may be revised by entering a new value in the appropriate model cell.

2. Enter the information to define the fuel cell systems configuration. Enter:

Peak Electrical Demand in $\mathrm{kW}$ for the system

Peak Thermal Demand in BTU per hour for the system 


\section{Fuel Cell \\ Cost of Ownership Model \\ Input Parameters}

User Input Parameters for Model Case No.

$$
\text { Enorgy lear Clas }
$$

Orice Buildings or Other Day-Time Only Uaers

Peok Electrical Demand, kw

Peak Themal Demand, Btu/hr

Fuel Call Electrical Capocity, kw

Doys of Operdtion (Dernand) per Year, Dors

Avaibibility. DMLS

Mean Time Between Failure.hr

Mean Time Between Overtoul. hr

Comfort Heating Copocity. Btu/hr

Cocling Capocity. Tons

Rotio of Electric Copocity Used to ldie Copocity

\section{Copilal Cost Input}

Fuel Cell inticial price, s per kW

Fuelcell Monutacturing leaming rate, \%

Absorption Cooling Used in Central Plant?

Thermal Accumutotor Used in Central Pant?

Oporating cas Input

Notural Gos Commodity Price. Current Year S/mmbtu

Notural Gas Price Grown Forecast

Electricity Purchose Rote Source

Select one

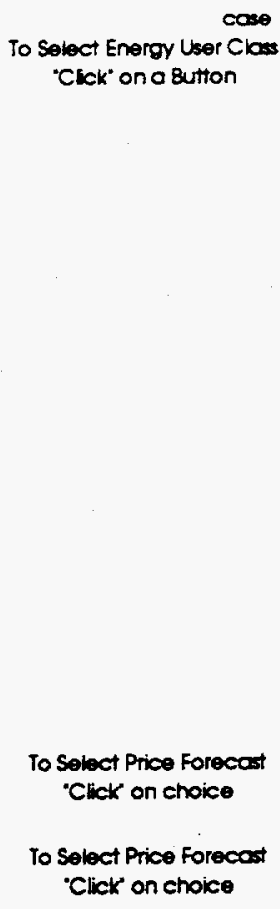
To Select Price Forecast
"Click on choice
To Select Price forecast
"Click on choice

Yes No No
Yes No

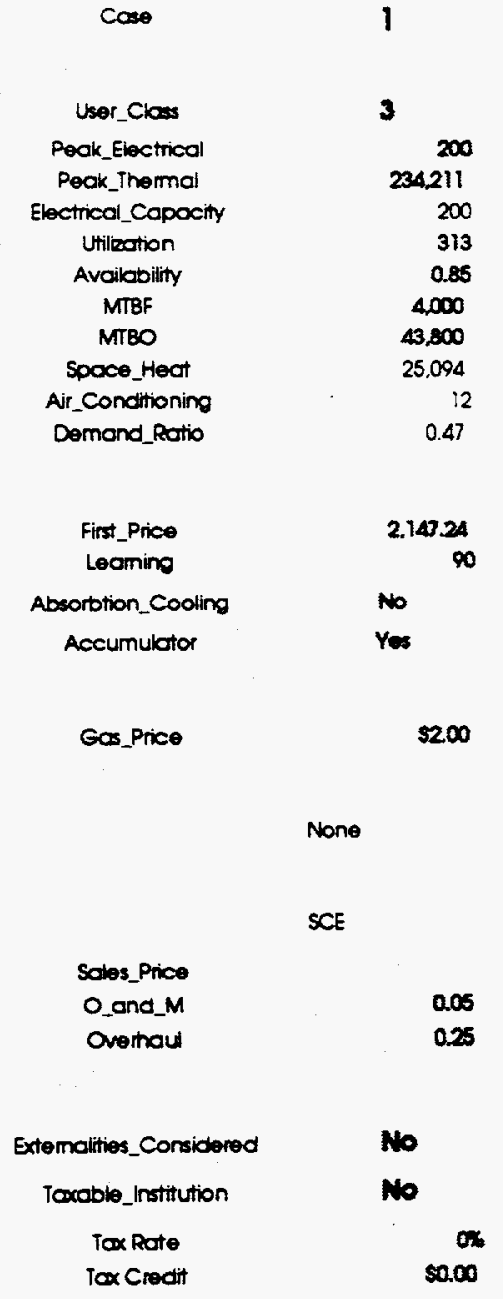


For Energy Class IV enter the Fuel Cell Electrical Capacity in kW-

The model sets fuel cell capacity equal to the peak electrical demand for Energy User Classes I, II and III.

Verify or revise the:

Days of Operation per year

Availability of the Fuel Cell, expressed as a percentage

Mean time between failure in hours of operation

Mean time between overhaul in hours of operation

The model calculates the space heating and air conditioning capacity from the standard central utility plant model. To change these values enter new values for:

Comfort heating capacity in BTU per hour

Cooling Capacity in tons

3. Enter the information necessary to define the capital cost. Enter:

The Initial price of the fuel cell in \$ per $\mathrm{kW}$

The assumed manufacturing learning rate as a percentage

4. Define the type of cooling and thermal accumulator included in the central utility plant.

Select yes to include absorption cooling in the central utility plant, to exclude enter no.

Select yes to include a thermal accumulator in the central utility plant, to exclude enter no.

5. Enter the first year Natural Gas Commodity Price in $\$$ per million BTU.

6. Accept or Revise the primary Operating Cost Parameters of the model by choosing one of the option buttons. Select:

The source of the natural gas commodity price

The source of the natural gas price growth forecast

The electricity purchase rate source

7. Accept or Revise the elements to define the fuel cell revenue from power sales and the cost of maintenance and overhaul of the fuel cell.

The electricity sales price in $\$$ per $\mathrm{kW}$ hour

The operating and maintenance as a fraction of capital cost

The fuel cell overhaul cost as a fraction of capital cost 
8. Accept or Revise the Operating Incentives Parameters by choosing one of the option buttons.

The user defines the applicability of environmental offsets.

Enter yes or no to define if the owner's operation is taxable.

Enter yes or no to select the Federal Income Tax rate percentage applicable to the owner. When the owner is taxable, the model calculates the Federal Energy Production Tax credit in \$ per million BTU. When the owner is not taxed, the model ignores the tax credit.

Section Two - Model Output Parameters

On the second page of the Cost of Ownership Model are the resulting values for Operation, Operation Cost, Capital Equipment Cost and Economic Benefits. These values are calculated using the input values for the case. To revise these values, change the Model input parameters .

1. Review the model values for the case. Of primary importance are the figures of Net Benefit and Figures of Investment Merit.

2. Before printing the results summary, revise the setup header information to define the specific case. The model uses the Excel print command. Therefore, select the page setup. Select the header information command. Type a brief title for the case in the central box in the header setup form. This step should be repeated for each new case.

\section{Section Three - Cost Of Ownership Model Detail}

As shown on the following page, the model summarizes the detailed information from the three sub models and the model constants which are the basis for the specific case. The user may revise any of these data by changing the source cell or the formula indicated in the model cell. 


\section{Fuel Cell \\ Cost of Ownership Model \\ Output Parameters}

Model Output Parameters for Case No.

1

Otfice Buildings or Other Doy-Time Onty Usere

\section{Operation}

Dality Averoge Electrical Energy Produced, kWhr

Biling Demand. $k w$

Fuel Cell Outages. Events per Yeor

Fuel Cell Thermal Energy Produced. Btu/hr

Average Daily Boiler Themal Energy Produced. Btu/ht

Daily Fuel Cell Gas Consumed. Cubic Feet/Doy

\section{Operoting Cost}

Annual Fuel Cell Notural Gos Purcheses

Boiler Fuel Purchosed. S/Mr

Bock-Up Boiler Fuel Punchased, S/M

Bock-Up Elactric Senvice Cost, S/MT

Bock-Up Electric Demend Charges. S/y

Other Electricity Purchase, Includes Tronsmission, Demand Chargess

Rautine Operations and Mointenance

Annual Reserve for Equipment Overhoul

Capital Equipment Depreciction, $S / y r$

Local Property Taxes. S/Yr

Fuel Cell Total Cost, $s$

Daily Power

Failures

Daily Themo

Daily Boiler

200

Daily Gos Consumed

$29.8 E+\infty 6$

$\infty 0.0 E+\infty$

$03.0 E+04$

Balance-of Plont Total Cost. \$

Total Copital Costs, S

Annual Cell Gos

Annual Boiler Fuel

Aock-up Boiler Fuel

Bock_Up_Electric

$\$ 15.88$;

so

$\$ 2,803$

$\$ 10.275$

Bockup Demand Charges

Make Up Purchose

$\$ 13,406$

$$
\text { CondM }
$$

Overtoul

Depreciction

Property_Toxes

Operoting

so

$\$ 16.813$

$\$ 14.291$

so

$\$ 7.504$

$\$ 73,468$

\section{Ther Plom Cost \\ Fuel Col Cost \\ Total Captal}

$\$ 336,252$

50

Fuol Cell Eenoits

Electric Energy Purchose Avoided, S/Yr

Electric Demand Charges Avoided, \$/Yr

Electric Energy Produced for Sole. S/Yr

Fuel Cell Themal Eneroy Purchcse Avoided, S/yt

Boiler Thermal Energy Benefit, $\$ / M$

Environmental Credits. $\$ / y r$

\section{Not Boneilts (Costs)}

Total Operating Cost

Operating Cost
Revenues

$(\$ 73,468)$

$\$ 121.795$

Net Benefit (Loss) Betore Federal incomeTcxes

Toxable income

Other Enterprise income

Federal Income Toxes

Fual Cell incorre. S/yr income

Operating Expenses (Less Depreciation)

Depreciction

Local Property Tcxes

Income Toxes

Federal Energy Tox Credit

Net toxes

Income After Toxes
Other_Revenue

FuelCell_Revenue

Operoting_Expenses

Federal_Depreciction

Property_Taxes

Toxable_tncome

Toxes

Credit

Net'income_Tox

income_Atter_toxes

Net_Present_Voive

Flgures of Investment Mert

Net Present Volue of the (Loss on) Investment

Intemal Rote of Retum, $\%$

Broak Even, years

Cost of Electricity Produced, $\$ / \mathrm{kWh}$

Averoge Cost of Electricity Purchose Avoided, $s / \mathrm{kWhr}$
internal_Rote_of_Retum

Break_Even

Power

Avaided_Pawer
$\$ 207,802$

$10.02 \%$

so. 13106

50.11176 


\section{Fuel Cell \\ Cost of Ownership Model \\ Calculated Values and Model Constants}

\begin{abstract}
Electric Power Produced Daily, $\mathrm{kW}$ 'hr
fuel Col thermal Energy Produced, Bru/Dor

Fuel Cel Gos Consumption. Btu/Doy
\end{abstract}

Fulcell Eneroy Copact

space Conditoning and Thema Energy

For 240 Whter Dors. Hecting. Btu

For 119 Summer Doys. Al Conditoring, Bth.

Baknce of the Arrual Thermal Energy Demand. Btu

summer Thermol Energy Demand. Btu

Whter Themal Energy Demand, Bts

summertme fuel Cell Themal Production.8tu

supolemental Summer Thermal Eneroy Reaured (Excess). Btu

supplamenta Winter Thermal Energy Reculred (Excess), Bru

\author{
Daily_Power \\ Daity_Thermal \\ Daily_Gas_Consumed
Heating
Cooling
Other_Thermal
Winter_Thermat_Demand
Summer_Fuelcell_Thermal
Winter_FuelCell_thermal
Summer_Boiler_Thermat
Winter_Boiler Thermal \\ Summer_Thermal_Demand
}

3.071

1.27E+07

$2.98 E+07$

$1.48 E+08$

$3.13 E+08$

$9.54 E+08$

$1.27 E+\infty 9$

$1.10 E+\infty$

2588849849

5351740023

0

CENTRAL UTIUTY PLANT MODEL CONSTANTS

Totd Amud Thermal Enoroy Poqutements

Thermal Energy Avallable (Shorttoll)

Acollory Boller Roguremerms.

Madmum required mokeup boler capoctly, Bu/m.

Bockap Comfort Hooting Capactly, Btu/r.

Ar Condtioning concentirator ioop temperature booster

Boller Oulput, Brumr

Mscelianeous Equpment

Accumuator Storoge Copoctiy. Gai.

Tower Copocity. Tons

Cooing Pump Copocthy. Ho

Hot Water pump Capactry. Hp

Chiller Pump Capacity. Ho

Tower Pump Capacity, Hp

$\begin{array}{cr}\text { Makeup_Boiler_Capacity } & 0 \\ \text { Space_theat_Boller } & 25,094 \\ \text { AC_Thermal_Bocster } & 29,254 \\ \text { Boiler_Output } & 29,254 \\ & \\ & \\ \text { Volume } & 150 \\ \text { Cooling_Tower_Capacity } & 103.632748 \\ \text { Cooling_Pump Capacity } & 0.60 \\ \text { Hot_Water_Pump_Capacity } & 0.16 \\ \text { Chiller_Pump_Capacity } & 5.59 \\ \text { Tower_Pump_Capacity } & 4.19\end{array}$

Btu per kllowatt hour

Watt"hr per Btu

Btu per refrigeration Ton $\mathrm{Hr}$.

Pounds per Gallon of Water

Ratio of thermal energy produced to electrical energy produced

Ratio of Fuel consumed to electrical Energy, SCF/kWhr.

Boiler Efficiency. Ratio of output energy to input. DMLS

Heating Value of Natural Gas, Btu/SCF. HHV

Winter Season for heating and Off-Peak Electric Rates, Days

Summer Season for cooling and On-Peak Electric Rates, Days

Levelized Capltal Cost Factor. DMLS \% of Capltal Caots/Year

Local Industrial Property Taxes, \% of Depreciated Capital

Federal Income Tox Depreciation Lfe, yr

Discount Rate, \%

Federal Income Tax Rate

Federal Energy Tax Credit

$\begin{array}{cr}\text { Btu_per_kW_Hr } & 3413 \\ \text { WattHr_per_Btu } & 0.2929 \\ \text { Btu_perTon_Hr } & 12000 \\ \text { Lb_per_Gallon } & 8.33 \\ \text { Hrate } & 4250 \\ \text { Gasrate } & 9.5 \\ \text { Boiler_Efficiency } & 0.9 \\ \text { Heating_Value } & 1000 \\ \text { Winter } & 246 \\ \text { Summer } & 119 \\ \text { Amortization } & 10 \% \\ \text { Property_Tax_Rate } & 2 \% \\ \text { Tax_Life } & 20 \\ \text { Discount } & 8 \% \\ \text { Tax_Rate } & 30 \% \\ \text { Tax_Credlt } & 50.85\end{array}$




\section{Review of Regulatory Issues}

Introduction

The opportunity for power sales from a distributed fuel cell application could arise from user demands decreasing to below capacity, or from designing output purposely above peak user demand. Market availability for such sales as well as the costs incurred for participation in this market is of primary interest to the question of fuel cell economics.

Utilities purchase power from Independent Power Producers (IPP's) such as fuel cells installations. In certain scenarios utilities are required to purchase power rather than generate their own. Small power producers entering power sales contracts must consider interconnection costs for grid access as well as backup charges to provide reliable service to users.

Of particular importance to IPP's is the implications of the PURPA act of 1973. PURPA was a legislative response to the oil crisis, and was designed to reduce national dependence on foreign oil. PURPA encourages research and investment in alternative energy sources. The Act promotes electricity producers with the highest thermal efficiency and most effective use of renewable and waste resources. The fuel cell benefits directly through the provisions of PURPA.

Prior to PURPA, the electricity market was considered a "natural monopoly." Large scale investor-owned utilities (IOU's) were the sole producers and suppliers of energy. These utilities were strictly limited by government as to what prices and profit margins they could attain. Market monopolization under strict regulation was believed to be the most efficient and affordable method for generation and distribution of electricity due to the vast economies of scale associated with the industry. The Public Utilities Regulatory Policy Act (PURPA 1978) challenged this traditional market.

PURPA, as implemented by the Federal Energy Regulatory Commission (FERC) created the Qualifying Facility (QF). QF's are independent power facilities which may be smaller than traditional utility plants, and or use an alternative fuel source. Under PURPA, IOU's must purchase power from QF's at the Utility's "Avoided Cost" of providing that power themselves. PURPA thereby forced open a new market for alternative technologies.

The introduction of the Qualifying Facility was an attempt to capitalize on the various QF benefits to society. It was hoped that QF's, like fuel cells, would 
reduce reliance on fossil fuels. Additionally, it was felt that by diversifying the energy market and increasing competition that the long run effect would be lower energy prices, increased load management flexibility and increased reliability.

In order to maximize potential revenues fuel cells must enjoy all benefits of PURPA. (see Appendix V) by achieving QF status. QF status can be achieved through self certification or by FERC certification. Self certification requires a letter to FERC documenting that the proposed facility meets the following requirements:

Produces electricity and other forms of useful energy (heat, steam, hot gasses, etc.) for industrial, commercial, heating, or cooling purposes through the sequential use of energy (general QF definition).

It is not more than fifty percent $(50 \%)$ owned by an electric utility or electric holding company.

Meets operating or proficiency standards.

Additional questions as to QF status are answered through FERC's certification process.

To apply for commission certification a potential QF must submit a project plan with all pertinent information on applicable operating and efficiency standards. At this time, interested parties must also submit a FERC form for Federal Register Notice. This publishes the proposed project on the Federal Register. Petition to intervene or protest for QF status must be initiated within 30 days of this publication. Within 90 days of application receipt FERC issues its decision. If no decision is given within 90 days, certification is automatic. 1

Ownership Implications

Ownership scenarios can effect an independent power producer's (IPP) Qualifying Facility Status under PURPA. The sale of power from an IPP to more than two users, more than fifty percent utility ownership, and positioning the IPP in a "public trust" situation can all jeopardize QF status. Any time an IPP serves more than two users (a co-generation facility selling power and thermal energy to a separate user with excess electricity being sold to the local electric utility has two users) it is examined for "public trust." If the IPP is the only supplier of

${ }^{1}$ Cogen. Handbook, section 5-7. 
energy to the user (no utility backup) then that IPP is in a public trust situation and is regulated as a public utility, subject to extensive regulation and redundancy standards. The IPP loses QF status. ${ }^{2}$

The fuel cell analysis examined three major ownership scenarios: Utility Ownership, User Ownership, and Third Party ownership. Both the Utility Ownership and the Single Owner/User scenarios do not impede QF status. The Third Party ownership (leasehold arrangement) and Multi-Owner/User ownership scenarios can, however, jeopardize QF status if handled improperly.

A shopping mall or strip mall is an example of third party ownership. A fuel cell would be located on-site, and the mall owner provides both thermal and electrical energy to the tenants. Rent or lease rates would include utilities for the tenants. Any excess power would again be sold back to the utility. A Multi-Unit Residential housing development is an example of the Multi-Owner/User scenario. In this case the fuel cell would be owned condominium-style. All the members of a planned urban housing development own a share of the fuel cell. Excess electricity would be sold back to the utility. For all scenarios, back-up power would be provided by the local utility as is required by PURPA.

2 P.U. Code 216 (b) "Whenever any... electrical corporation... delivers a commodity to the public or any portion thereof for which any compensation or payment whatsoever is received, such ... electrical corporation .. is a public utility subject to the jurisdiction, control and regulation of the Commission.."

* P.U. Code 216 (d) provides: In no event shall ownership or operation of a facility which employs cogeneration technology...

be deemed to make a corporation or person a public utility, within the meaning of this section, solely because of the ownership or operation of such a facility.

P.U. Code 218 (a) "'Electrical Corporation' includes every corporation or person owning, controlling, operating, or managing any electric plant for compensation within the state, except where electricity is generated on or distributed by the producer through private property alone solely for its own use or the use of its tenants and not for the sale of others.."

* P.U. Code 218 (b)"Electrical Corporation" does not include a corporation or project employing cogeneration technology... for the generation of electricity solely for any one or more of the following purposes:

(1) It's own use or the use of it's tenants.

(2) The use of or for sale to not more than two other corporations or persons solely for the use on real property on which the electricity is generated or on the real property adjacent thereto.

(3) Sale to an electrical corporation or state or local public agency, but not for sale to others, unless the corporation or person is otherwise an electrical corporation.

The asterisks $\left(^{*}\right)$ above designate the statutory exceptions created for QFs within current regulation. 
Under current regulations, none of these ownership scenarios would jeopardize QF status as long as utility bills were not differentiated ${ }^{3}$. Differentiated billing would imply sale of power and would place the IPP (fuel cell) in a public trust situation liable for back-up power, reliability, etc. As the fuel cell would be owned by the users in the case of the Multi-Owner/User scenario, QF status would be maintained as long as bills were not differentiated here either.

\section{Avoided Cost Price Offers (Buyback)}

Almost all QF's in the Los Angeles basin will sell excess power to Southern California Edison (SCE). ${ }^{4}$ The utility buys power in two forms, through two separate contracting options: as available capacity or firm capacity. As available capacity entails a simple short-term contract under which surplus energy from QF production or operation is automatically routed to the grid. The amount of electricity routed to the grid is metered daily and compensated for by the utility. The price paid for this energy is the "incremental cost to the Utility of Alternative Energy. "5 In its most simplified form, this is the "avoided cost" of utilities for the incremental amount of fuel necessary to achieve the electrical output provided by the QF.

Firm capacity contracts are usually longer term contracts established between Utilities and Qualifying Facilities. Firm capacity contracts specify the amount of power a QF must provide under the terms of the contract at a specific "on line" date until the contract expires. These contracts are made available in response to the California Energy Commission's (CEC) Biennial Resource Update conclusions on future power capacity needs. These decisions are made in conjunction with the individual utility's Resource Plan. The California Public Utilities Commission (CPUC) evaluates these reports and decides whether or not firm capacity contracts will be necessary to meet upcoming demand. The utility announces the availability of long-term contracts in which price is based on the fixed cost and variable cost of the avoided resources used. In this case "fixed cost" entails the deferral of planned capacity additions by the utility, such as large capital intensive power plants.

3Interview, Vivian Murai

${ }^{4}$ Ibid.

${ }^{5}$ CEC Electricity Report (1990), p. 43-44. 
The rates paid for excess QF power sold to the utility are broken down into two components; an energy component and a capacity component. The energy component is the simple cost the utility would have incurred to generate one more kilowatt-hour of electricity. This cost is a function of the primary fuel costs. In the past, these primary fuel costs were a function of the total amount and respective quantity of coal, oil, and natural gas used

Over the last ten years, utilities have moved increasingly away from coal and oil towards reliance on natural gas as the primary fuel. The Utility Data Institute (UDI) predicts natural gas will fuel most of the new electricity generating facilities built in this decade. According to the UDI's latest study of power plants, total gas fired electricity generating capacity constructed between 1990 and 2000 will exceed 52 gigawatts. ${ }^{6}$ The energy component used for avoided cost energy calculation reflects this shift toward natural gas and the energy component of price offers is thereby tied to natural gas prices.

The capacity component represents the cost of production, transmission, and distribution equipment that the utility can avoid by reducing loads over various parts of its system. Typically, the capacity component is based on relative deferral of all or part of a planned utility addition(s) due QF contribution. ${ }^{7}$

Both components are summed together when assigning rates for "as available" and "firm capacity". Large facilities frequently take into account time of day considerations, factoring in the peak and off-peak marginal fuel costs. During peak hours utilities are forced to use even their most inefficient means of energy production (old facilities, etc.) which means their marginal fuel costs are higher. Thus electricity sold to utilities at peak hours will garner the highest price. Smaller facilities frequently do not take into account time of day into considerations (time of day metering costs are higher). These facilities are paid on a weighted average schedule. These average prices vary between one and two cents per kWhr depending on the time of day and season. By selling excess power to the utility at peak hours, a QF can garner up to one (1) extra cent per $\mathrm{kW}$ sold under the current schedule. A one cent increase in price offer for a $200 \mathrm{~kW}$ co-generation project such as a fuel cell could garner the project nearly $\$ 3500$ per year or an NPV of $\$ 23,656.57$ over ten years.

The capacity component is established as a function of the magnitude of specific commitments that QF's provide over several years. It is based on energy shortage costs as determined by adjusting the costs avoided by the deferral or

6Natural Gas Industry, October 1993, p. 449.

${ }^{7}$ Cogen. Handbook, section 5-6. 
avoidance of large scale combustion turbine construction using an "Energy Reliability Index." Implicit in this deferral cost is the cost of air quality regulations with Best Available Control Technology (BACT). Therefore, the portion of the price offer affected by the capacity component depend largely on the amount of commitment (overall baseload capacity) combined with the reliability of that commitment 8

Capacity rates for new contracts are adjusted every two years; real capacity rates are fixed for the duration of the contract. 9 Capacity rates offered must be approved by the CPUC. Because of CPUC approval is required for the price offers, regulatory interests are considered. The CPUC has expressed an interest in both deregulating the industry as a whole and reducing basin-wide emissions. "All parties support increased competition among potential suppliers of electricity to California....Our goal is to arrive at what has aptly been called "environmental least cost" resource planning."10 Increasing CPUC interest in QF capacity expansion manifests itself through a trend toward higher capacity offers. Infrequently, agreements on rates can be negotiated on a case by case basis subject to the review of the CPUC.

It is important to note that both avoided cost price offers and retail energy rates reflect the large variety of external costs borne by the utility. Included in these external costs (externalities) are the utility's regulatory obligations. Air quality abatement costs are becoming increasingly significant for all sources in the South Coast Basin. The implication of increasingly stringent air quality regulations is both higher price offer and retail energy rates as BACT requirements are increased

Unfortunately, "avoided cost" rate paying systems are not without flaws. There is simply no objective measure of a utility's "true avoided cost." Utilities agree to price offers pursuant to a diverse set of long-term supply relationships. ${ }^{11}$ The diversity of the contractual relationships themselves given different capacities, reliability levels, fuels, and technologies do not lend themselves to such a standard spot pricing system. As a result, there is tremendous support for the

8 lbid., section 5-8.

${ }^{9}$ Cogen. Handbook, section 5-8.

${ }^{10}$ ALJ Decision 91-06-022, p. 8, 2 respectively.

${ }^{11}$ lbid., section 5-9. 
concept that a market clearing price should come out of bidding scheme or similar procedure.

\section{Existing Contracts}

The CPUC created the Standard Offer 1 (SO1) to contract for short-term "as available" capacity. This is the contract for Qualifying Facilities which have excess capacity to sell but cannot be counted on to provide a firm commitment at peak hours. For those QF's who can commit but only for the short-term, Standard Offer 2 (SO2) has been used. Also for short term is Standard Offer 3 (SO3), which is a simplified version of SO1 for capacities of less than $100 \mathrm{~kW}$. In March of 1986 the CPUC suspended SO2. ${ }^{12}$ Current PUC Administrative Law Judge (ALJ) Opinions indicate that this suspension will be permanent. ${ }^{13}$ As a result, the only contracts currently available are the "as available" SO1 and SO3 contracts.

In the early 1980's the CPUC developed the Interim Standard Offer (ISO4). This provided for long term arrangements between QF's and utilities. The offer quickly became over-subscribed and was generally considered to jeopardize the reliability of the utility's future energy capacity. This was due to the fact that there was no assurance that any of these proposed projects would actually produce to their estimates or come on line at all. In 1984 ISO4 was suspended for those reasons. ${ }^{14}$ It was reinstated with addition of a QF milestone procedure (QFMP) used to check project progress. QFMP prevented developers from grabbing at opportunities before thoroughly researching their ventures. The revised ISO4 also forced projects to be accountable to their offers with a series of interim progress checks. If the checks were not met, the contract could be forfeited. Theoretically, this gave utilities enough time to reevaluate their energy supply scenarios and re negotiate contracts to meet their future needs. The revised ISO4 was not entirely successful, and was permanently suspended in 1985.15

12Decision 86-03-069

13Decision 86-05-024.

14DRA, 3-5.

15 Interview, Torribio, 4-16-92. 
The CPUC has issued the new Final Standard Offer (FSO4). ${ }^{16}$ FSO4 differs substantially from its predecessors. Regulators believe it will provide for more stable, long term contracting. FSO4 derives its price offers from a utility's longrun marginal costs. These costs are determined from the respective utility's resource plan, including all cost- effective potential generation additions (e.g., new plant construction, refurbishment, power purchases). These additions to capacity are termed Identifiable Deferrable Resources (IDR's) The IDR's estimates include estimated costs for permitting and environmental mitigation. Those estimates are known to the bidder in advance. The IDR can be considered the utility's bid for new generation capacity.

Under FSO4 auction methodology, QF's bid against the utility avoided cost benchmark computed from the projected capital and operating cost of the IDR. The second price auction rules require that QFs displacing the IDR receive payments computed from the lowest losing QF bid if their is an over subscription. If there is an under subscription, all bidding QFs are winners and receive payments computed from the full projected costs of the IDR.

Price offers under FSO4 are based on the fixed and variable costs associated with each respective addition. Under FSO4, utilities are also authorized to pay for such performance features as the option of temporarily reducing a QF's output at the utility's direction. 17 FSO4 contracts will be signed for periods of fifteen (15) years.

Preliminary estimates for FSO4 offer prices (buyback rates) are between 1 and 3 cents per $\mathrm{kW}$ above current offer levels. This puts FSO4 offer projections at a net of between 4 and 6 cents per kW. 18 A price offer of 5 cents per $\mathrm{kW}$ would garner the fuel cell owner an additional $\$ 8000$ per year over an "as available" contract. Over a ten year period this translates into an NPV of $\$ 54,072.19$.

Before 1993 only SO1 and SO3 contracts were available for QF's. ${ }^{19}$ As a result, QF's are only liable for "as available" capacity, and are paid through a "capacity rate" offered in cents/kW using a combustion turbine as a proxy for shortage costs; in addition to an "energy rate" equal to the price of marginal fuel -

16 bid.

17ALJ Decision 91-06-022, p. 4.

18Intenview Torribio, 6-18-92; Terrence Hee, 8-14-92.

19 Joskow, pg. 24. 
incremental energy rate Btu/kWhr which is time differentiated. 20 (see appendix IV for example of price determination).

In 1993 the issuance of FSO4 represents the PUC's latest attempt to incorporate non-price factors into Standard Offer contracting. The environmental considerations and valuations associated with $\mathrm{FSO} 4$ foreshadow similar changes to existing "as available" contracts, SO1 and SO3. One provision of FSO4 allows conversion of FSO1 contracts to FSO4 status.

Currently, only Qualifying Facilities can sign either a SO1 or the emerging FSO4 contract. Projects are paid the going rate for energy provided comprised almost entirely of the energy component given the suspension of any long term contracts. QF's are thereby subject to an effective price cap. Their financial performance is solely based upon ability to control costs and achieve high plant performance levels. 21

Standard Offers are not the only way to structure the QF generation procurement system. Many other states have experimented with competitive bidding programs to solicit QF power. One option considered and supported by the CPUC is "all-source bidding" where all potential suppliers may subscribe to provide capacity. Impeding the adoption of such a bidding system are two primary issues. First, the absence of a functional way to quantify the value of non-price factors (environmental). Second, issues like "wheeling" have yet to be entirely settled. There are several variations on the bidding systems, but generally, the regulator sets the quantities and prices are a fall out of the cleared market, subject to ceilings defined by non-QF bulk power supply alternatives. 22 This is thought to be much more practical than a system that caps price but has no cap on quantity. Bidding programs are gaining widespread support and may be in implemented by the time fuel cell projects are on line.

Interconnection, Metering, and Grid Access

Fuel cell entry into the current QF market is related to the cost of interconnection into existing utility grid. Currently, QF's are guaranteed utility interconnection. QF's do, however, remain largely responsible for much of the system's set up costs as well as upgrade costs. These costs have put excess burdens on QF's

20 lbid., pg. 21.

${ }^{21}$ lbid.. pg. 16.

22DRA, pg. 35. 
and are under inspection by the CPUC. QF's are financially responsible for the design, installation, operation, and maintenance of all equipment necessary for grid connection. In addition, the QF may also be responsible for system upgrades necessary for transmission and connection to the system. Furthermore, the QF must assume any responsibility for protection of equipment should disturbances in the system occur. 23 These significant financial liabilities have stymied many co-generation projects.

Qualified Facilities in the South Coast Basin located within Southern California Edison's (SCE) service area are regulated by Edison Tariff Rule No. 21. Tariff Rule 21 outlines the specific switching, protection, and relaying equipment needed for interconnection with SCE lines. Other basin utilities sources maintain similar interconnection requirements for QF's. The interconnection equipment required for grid access is fairly standardized. Components required vary in size with the rated capacity of the facility. Appropriate switching and relay equipment for SCE interconnection is already included in the capital cost estimate of the fuel cell capital cost model. 24 .

Line upgrade costs are a function of the amount of additional power being put into the grid beyond currently line rating. For relatively small facilities (in the 200 KW range) these line upgrade costs are often negligible as few upgrades (with the exception of transformer changes) are necessary. 25 Most often, existing lines in urban areas are adequate to carry these additional loads/capacity. The cost of ownership model considers the costs associated with interconnection and line upgrade.

Metering for power sold back to the grid can be done two ways. Time of day metering is practical for QF's selling relatively more power at "on peak" times. Time of day meters record both the time and amount of power sold so that users selling power on "peak" times can garner the highest price. Average metering is used on smaller facilities that have less "on peak" power to sell. Such facilities may actually benefit from the average metering method when they have high power sales at "off peak" times, as the time-weighted average price offers are higher than "off peak" prices. Both types of meters are measured monthly. Time of day and average metering costs are one time costs .

23 lbid. pg. 36.

24Terrance Hee, Gas Company 8-14-92

25 Interview, Torribio, 6/18/92. 
Use of utility owned transmission facilities is called "wheeling." The industry cannot function fairly or competitively until wheeling issues are resolved. 26 The CPUC is currently in the process of establishing policy on transmission access consistent with a workable competitive market and all source bidding. 27

Three questions the CPUC intends to resolve are:28

1. How should a bidding process account for transmission costs in selecting QF's?

2. Who should bear the costs of transmission system upgrades to accommodate QF's that want to participate in the bidding process?

3. What are appropriate access and price rules for wheeling? (sales to utilities or users by way of other utilities, intermediary for transfer only)

The commission also developed five goals: (proceeding 90-09-050)29

1. Provide nondiscriminatory transmission access to non-utility power producers, to promote competitive generation;

2. Price transmission services at cost, to promote efficiency and preclude cross subsidization;

3. Ensure reliable service at the lowest possible cost;

4. Account for the environmental impacts of transmission facilities and their implications for the extent of possible future development;

5. Avoid a regulatory mechanism that would overburden parties or CPUC staff.

Two recent decisions made by the CPUC address wheeling and interconnection costs respectively. ${ }^{30}$ The first decision asserts that interconnection of QF's outside of service area should be no different than any transaction within. The implication here is that utilities must provide transmission services at "cost" rates that have yet to be decided. The second decision addresses the payments for transmission line improvements. This decision provides that QF's are

26DRA, p. 30.

27DRA, p. 31, Proceeding 90-09-005.

28 Ibid.

${ }^{29}$ So. Cal. Metering, p. 3-4.

${ }^{30}$ Decisions 88-04-0700, 91-04-040. 
responsible to upgrade those lines that are only beneficial to themselves. System wide benefits should be born by the consumer.

This is a national trend. Congress, in the Energy Policy Act of 1992, expanded section 211 of the Federal Power Act. Under expanded section 211, FERC can order transmission, upon application, if it is in the public interest and if it will not unreasonably impair reliability. The application for FERC ordering of transmission cannot be made until 60 days after the applicant has made a good faith request to the transmission owner. In July of 1993, the Commission issued a policy statement delineating what would be considered a good faith request and a good faith response. In its notice of inquiry (NOl) into transmission pricing services the Commission invited comments on the scope of the it's discretion on transmission pricing under section 212 of the Federal Policy Act. The NOI included a staff paper asking for comments on 36 different matters relating to the proper measure of pricing transmission services; including compensation for all costs and financial incentives to provide service. The 36 questions are a clear indication that FERC is contemplating a through restructuring of its transmission pricing policy. Many believe the result of NOI RM93-19 will be the electric power industry equivalent of Order 636.31 In essence, wheeling is a fact. Only the details remain.

In addition, the Energy Policy Act prohibits the Commission form regulating retail wheeling. But it is not clear whether or not the states have the authority to regulate retail wheeling. The industry assumes retail wheeling will happen; when is just a matter of time. 32

Quantifying the effects of such regulatory proceedings is difficult, since the effects of such regulatory changes have yet to manifest themselves. Though small QF's like the fuel cell may not require direct wheeling arrangements with other individual users, emerging regulations regarding such issues do affect fuel cell economic viability. As the industry moves away from traditional thinking about power (monopolies), QF price offers and prices charged to consumers will come closer together.

Current pricing scenarios reflect a considerable discrepancy here of at least 6 to 8 cents per $\mathrm{kW}$. Presumably, the utility is charging this amount for transmission and load management. As the industry continues to adopt more liberal wheeling and interconnection policies we expect this anomaly to be reduced. These factors into consideration through the sensitivity analysis on buy-back (price

31 Cogeneration Monthly Newsletter, September 1993.

32 Remarks by Martha O. Hesse, Gas for Electricity: Bridging the Gap, Houston, Texas, October 5, 1993. 
offer) rates. Sensitivity analysis using higher buy-back rates (closer to retail consumer costs) reflect a more liberal regulatory environment towards wheeling and interconnection. Conversely, analysis done using lower buy back rates (consistent with current rates) reflect a more traditional regulatory environment.

\section{Backup Costs}

Willingness of a Utility to supply backup and supplementary power to cogenerators at a reasonable price is an issue of importance to the economic feasibility of distributed fuel cells. For example, for a large scale production facility with the fuel cell providing $75 \%$ of the power, the owner must contract with the utility for the remaining $25 \%$ of the energy, and for backup of the full $100 \%$ of demand power if the fuel cell fails. This is termed a demand charge. All industrial facilities must pay a demand charge in addition to the energy charge.

At the present time, the CPUC assures QF's of backup power at "reasonable rates." The definition of "reasonable rates" has been the subject of much controversy and litigation. The CPUC is attempting to clarify the "reasonable rates" criterion, but the concept is further complicated when different reliability levels and capacities are considered.

Of interest to fuel cell owners are the demand charges which the owner would pay if they call on the grid for energy in the case of fuel cell failure. This charge is approximately $\$ 10.00$ per $\mathrm{kW}$ for each month in which the fuel cell is connected to the utility grid. If a $200 \mathrm{~kW}$ fuel cell was out of operation for 72 hours in the summer months, the demand charge would be $\$ 2000$ (200 $\times \$ 10$ ) plus the energy charge. Only residential customers are not subject to the demand charge.

For normal operations, Edison's common industrial rate schedule, TOU 8, includes a "time-independent" charge of $\$ 3.65$ per $\mathrm{kW}$ per meter per month. It is assessed on $50 \%$ of the demand of the previous 12 months. In addition to the "time-independent" charge the industrial user pays a demand charge that varies by the time of day and year. The schedule changes with the service voltage : $<2 \mathrm{kv}, 2>\mathrm{kv}<50 \mathrm{kv}$, and $>50 \mathrm{kv}$. The demand charges apply only if the time related demand exceeds the time independent charges. In no case would these charges approach the residential rate charges. 


$\begin{array}{llcl}\text { Season } & \text { Peak } & \text { Mid-Peak } & \text { Off-Peak } \\ \text { Summer } & \$ 15.80 & \$ 2.50 & \\ \text { Winter } & \$ 0.00 & 0.00 & \$ 0.00 \\ & & \end{array}$

Demand charges are relevant for every user identified in the User Demand Survey conduced as part of this analysis. Every user had a normal peak that was $30 \%$ higher than the average load, thus assuring that SCE will always collect summer peak demand charges. On average, the customer's demand will always be $50 \%$ of the previous twelve month's peak.

\section{Contract Brokering}

The CPUC allows that there are valid circumstances under which a holder of a standard offer may assign its contract to another party. The new holder of the contract may modify or change the current project. However changes that constitute an essentially new project may be considered contract brokering. Contract brokering occurs when a new project manager wants the terms that previous contractors were allowed, such as FSO4. Rather than risk the new market system, the new contractor simply buys into an existing contract and reestablishes the new project himself, under the old project guidelines. The CPUC tries to discourage speculative contract brokering in an attempt to create higher standards of performance for new entrants. Modifications that result in a new project would be in essence equivalent to lowering performance standards . These modifications include but are not limited to significant changes in emissions, fuel type, plant size, site, or primary technology. 33

Deferrals and Buyouts

Under Standard Offer Contracts, fuel cells, like other QF's, would be required to come "on line" (produce) within five years of the last contract signature for "firm" contracts. 34 Since the fuel cell's construction and set-up time is less than six (6) months from project start to completion such a deadline could be easily met. The CPUC has, however, laid out circumstances where deferrals or buyouts can occur. The general rule in these cases is proof that the rate payer's best interest will be served substantially by the buyout or deferral. A deferral can occur when a QF is behind schedule but is reliable and will benefit consumers, once in place.

33 lbid.

${ }^{34}$ Cogen. Handbook, section 5-6. 
In this case a deferral may be in order. Another type of deferral could occur when the utility has overestimated its demand schedule. Here the utility would be forced to raise rates if it was to take on the project. Hence the negative impact on customers again warrants the deferral.

The CPUC also allows for "buyouts." Here the utility pays the QF not to produce. This may be a paid deferral of a QF currently producing under outdated contractual terms and one which is no longer beneficial to the utility or the consumer. (This was a large problem with the over subscription of QF's to the initial Standard Offers which required utilities to pay excessively high rates. The utilities can now buyout these poor contracts)

\section{Purchasing Between Updates From QF's}

The Biennial Resource Plan Update (BPRM) allows the utility to perform long term planning. The CPUC studies the plan as well as the utility's demand schedule and decides how many long term offers are made available. A utility may, however, require resource additions to meet demand between Updates. The Commission recognizes this reality and requires that utility purchases reflect a clear consistency with their resource plans. A recent CPUC decision stated that demonstrating the reasonableness of the addition is the responsibility of the utility. 35 The commission will review all purchases.

\section{Re-negotiating Contracts}

Special circumstances may dictate that QF's are able to re negotiate a specific contract with a utility. The CPUC has determined that the only contracts that may be modified are those that pertain to "viable" projects. 36 "Viable" projects are those projects deemed functional under the current contract. No modifications are allowed to projects that can no longer meet the contract under its original specifications. Viability is determined by the CPUC after a submittal of all evidence, and review of reasons for desired modification.

\section{Market Trends}

As a further sign of CPUC commitment to the PURPA ideal, the CPUC has reinstated contracting for firm capacity to begin this Spring. This decision in combination with continuing work on all source bidding programs,

35DRA, p. 35-37, Decision 91-06-022.

$36_{\text {lbid. }}$ 
interconnection and backup access, as well as reevaluations of the "avoided cost" assumptions reflect the continuing push to diversify power supply and ensure a place for QF's. All sources echo the understanding that the energy market will continue to diversify. Clean, efficient, new technologies like the fuel cell are welcomed.

The emergence of all source bidding will be a function of the development of CPUC plans to quantify non-price factors associated with QF's. These factors include such areas as emissions and environmental effects. When the CPUC has developed a workable plan for quantifying these values then all-source bidding may take place. Once these values are quantified then the QF status may drop away, as the designation will have lost its significance; PURPA goals will be met through a market system instead of regulation. Such simplification of the energy market, as long as non-price factors are accurately accounted for, will further ease the fuel cell's entry into the market.

Emerging regulations on grid access and "wheeling" will further enhance fuel cell viability. As deregulation of the industry continues, technologies such as the fuel cell will be more viable. The current price anomaly between offer prices and retail electricity will be significantly reduced as utility's monopolies are removed.

\section{Current Environmental Regulations and the Fuel Cell}

The fuel cell, because of its low relative emissions, has the potential to reap large environmental benefits. When compared to present co-generation technology, it offers reduced NOx, SOx, ROG, and PM10 emission levels. With present environmental legislation, however, these benefits are not being realized. One of the major shortfalls of current SCAQMD regulations is that they offer no direct benefit to users operating equipment below emission threshold levels. Once a source's emissions are found to be at or below threshold levels, the source is exempted from any further environmental obligations. This approach negates the idea of creating capital and operating cost advantages for clean technologies by placing charges on pollution. For example, the most recent threshold limit set for new installations of boilers calls for NOx emissions of less than 30ppm. 37 The fuel cell operates with NOx emissions of less than $1 \mathrm{ppm}$ yet creates no direct economic benefit by doing so. 38

${ }^{37}$ SCAQMD Rule 1121.

${ }^{38}$ Terrence Hee, Gas Company, 8/10/92. 
Table I shows current SCAQMD emission thresholds and associated fuel cell emission levels. If the difference between these levels could be translated to a monetary benefit for the fuel cell, it would be quite large. Based on a unchanging NOx emission offset price of $\$ 2500$ ( $10 \%$ lower than the lowest RECLAIM estimate), a discount rate of $10 \%$, and a period of 10 years, the present value of a base case fuel cell in terms of NOx emission payment avoidance under a system without thresholds (like RECLAIM) is well in excess of $\$ 64,000.39$ This translates to quite a capital cost advantage unrealized due to regulatory barriers.

\section{Table 140 \\ Fuel Cell Emissions (Tons/Year)}

$\begin{array}{llllc}\text { Pollutant } & \text { 200KW } & 1.2 M W & \text { 2MW } & \begin{array}{c}\text { SCAQMD } \\ \text { Threshold }\end{array} \\ \text { NOx } & 0.167 & 1.002 & 1.67 & 4.0 \\ \text { SOx } & 0.00025 & 0.0015 & 0.0025 & 4.0 \\ \text { PM10 } & 0.000025 & 0.00015 & 0.00025 & 4.0 \\ \text { HC } & 0.167 & 1.002 & 1.67 & 4.0 \\ \text { CO } & 1.67 & 10.01 & 16.7 & 100\end{array}$

The discrepancy between fuel cell emission levels and SCAQMD thresholds results mainly from two factors: 1) Monitoring of source emission levels becomes more costly as the size of the source decreases, and 2) the definition of Best Available Control Technology (BACT) under SCAQMD Rules and Regulations poses obstacles to new, clean technologies.

Monitoring of Source Emissions

The problem of monitoring is one which will most likely be remedied under the new RECLAIM program. Along with other enforcement measures, the District plans to implement systems of real time monitoring (CEMS), quarterly and year end accounting, and site inspection, to ensure accurate calculation of overall District emission levels. These measures, along with the market trading scheme under RECLAIM should allow for reductions in thresholds in the near future.

${ }^{39}$ Calculated as $\mathrm{PV}=\ldots \mathrm{Vi} \div(1+r)^{\mathrm{i}}$

40"Rough Outline of Fuel Cell Input/Output Model", Jeff Towson, 1992. SCAQMD RECLAIM Proposal, 1992. 
The present threshold is based on SCAQMD findings that $95 \%$ of presently operating equipment would be covered by the 30ppm NOx limit. To monitor the other $5 \%$ would require extensive marginal expenditures and was not viewed as economically reasonable. 41 When a greater number of sources begin to fall under this threshold it will most likely be reduced to reflect emission levels achievable through new technology. Until incentives are offered to below threshold users, however, the relative number of these users will be slow to increase.

There will have to be some form of incentive devised for technologies able to surpass emission reduction goals. This will stimulate research into new environmentally benign processes and will expedite the achievement of overall air quality attainment as proposed in the Clean Air Act. One such incentive program is the fuel diversity section of RECLAIM.

SCAQMD defines BACT as:

the most stringent emission limitation or control technique which: 1) has been achieved in practice, or 2) is contained in any state implementation plan approved by the EPA, or 3 ) is found technologically feasible and cost-effective compared to measures as listed in the AQMP or subsequent rules. 42

By this definition, until fuel cell technology or similar alternative energy technologies become commercially viable, relatively commonplace, and as cost effective as present control technology, they will not be used as standards. SCAQMD regulations do call for examination of emerging emission control technologies. Due to economic considerations, however, these technologies must be viewed as easily attainable and cost effective before they are utilized in the setting of emission thresholds.

An example of this trend is natural gas. Over the past four years, the SCAQMD has been moving toward the adoption of natural gas as a standard by which other fuels are to be measured. This resulted in a plan to phase out other fuels, such as diesel, which had previously been used to set emission requirements.

In January, 1988 the SCAQMD Board adopted the Clean Fuels program. The program was designed to phase out the use of diesel, fuel oil, and solid fossil

41 Interview, Tim Little, 8-4-92.

42SCAQMD Rule 1302. 
fuels, substituting methane, propane, and alternative clean fuels. The phase out process began in 1992 and is proposed to continue through 1997 when all stationary sources will operate with emission levels equivalent to or below the most efficient natural gas-fired processes. At this time, the phase-out program calls for extensive research into the area of alternative energy sources such as solar energy and fuel cells. Once the natural gas standard has been achieved, a new baseline standard will be chosen from emerging, reasonably expected technologies. This analysis will consider clean alternative energy sources viewed as feasible within the next twenty years.

This policy seems consistent with the precedent set by diesel fuel in the early 1970 's. At that time diesel was considered the new clean fuel and was used as a standard for many stationary and mobile source fuels. With recent advances in natural gas technology and increased awareness about the environment, however, the pollution levels associated with diesel technology are no longer acceptable. This trend of adopting cleaner fuel standards as technology permits will most likely continue. This will obviously help fuel cells which seem to be one of the most feasible alternative energy solutions for the next two decades.

\section{Emerging Regulations and RECLAIM}

RECLAIM is a market approach to the control of pollution. It operates through the issuance of Emission Reduction Credits (ERCs) which can either be sold or used to meet a source's emission reduction requirements. This market approach would require new sources to purchase ERCs above the amount of their expected emissions (the present ratio is 1.2:1) in order to reduce overall emission levels in the basin. Similarly, sources which are either retired of altered to lower emission leveis will receive ERCs for the purpose of sale or offset of future expansion. The two main questions facing the designers of the RECLAIM market are: 1) how to price the ERCs, and 2) how to trade them.

ERC pricing remains an area of great debate. Most experts agree, however, that ERCs will increase in price drastically over the next decade. In a recent ALJ opinion one finding of fact was, "as cheaper offsets are bought up, the price of offsets will quickly rise to reflect the buyer's marginal cost of emission control." 43 With the SCAQMD's plan to raise emission control standards and general knowledge of the concept of diminishing returns vis-à-vis control expenditures, it is rather obvious that ERC prices will increase substantially.

${ }^{43}$ ALJ 6-5-91, p. 103. 


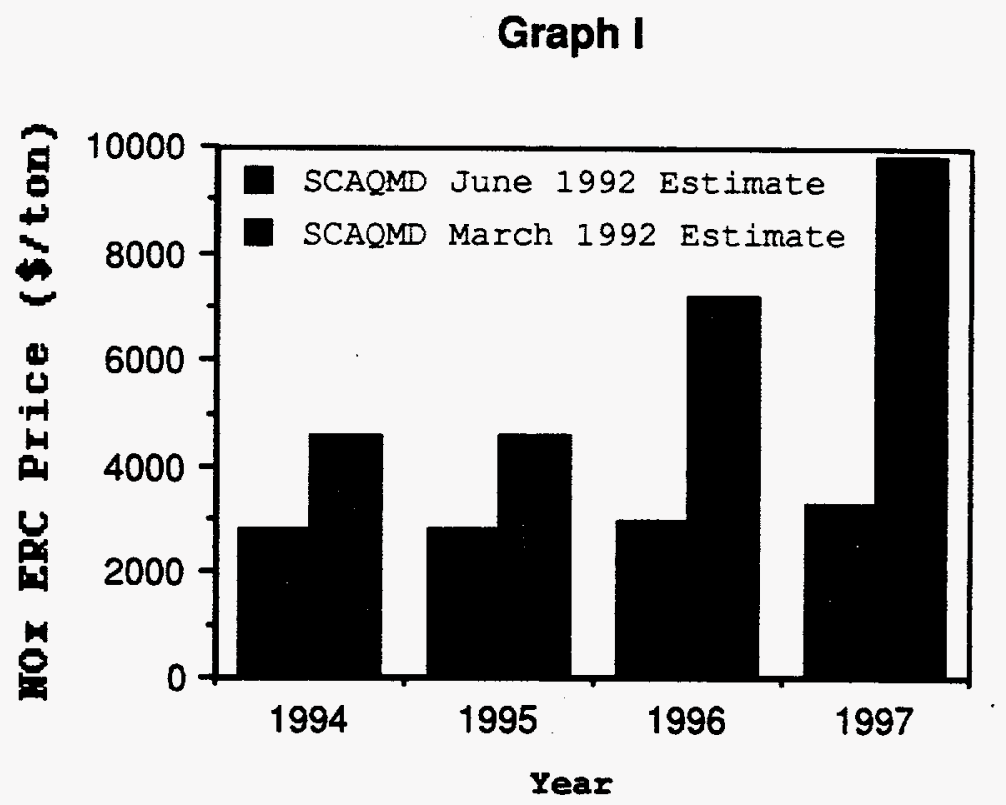

Upward trends in emission offset trading prices have already been recorded. 44 $\mathrm{AER}^{*} \mathrm{X}$, a leading national air credit advisor, tracked the trading price of NOx offsets between November 1990 and December 1991. With trading volume rising substantially, the price of an annual one pound per day offset rose from $\$ 2150$ to $\$ 2600.45$ SCAQMD predicted a continuation of this trend in its March 1992 draft of RECLAIM. The average price of NOx ERCs was expected to be $\$ 2800 /$ ton in 1994 with a potential price of $\$ 3300 /$ ton by 1997.46 Due to further research and valuation, these figures were revised in SCAQMD's June 1992 AQMP update which predicted NOx ERCs to increase in price from $\$ 4596 /$ ton in 1994 to $\$ 9783 /$ ton in 1997 (See Graph 1). 47

There is no agreement among the experts as to the exact price ERCs will fetch in an open market. What can be assumed is that the price will start low and

${ }^{44}$ Emission offsets have been traded since 1985 , but the market has been slow to develop. RECLAIM offers a more defined system which will make trading a necessity for many new and existing sources.

${ }^{45} \mathrm{AER}^{*} \times$ phone 6-18-92

46SCAQMD, RECLAIM, p. H-9.

47 (1987 \$). SCAQMD, Socio-Economic Impacts of the Proposed Amendments to the 1991 Air Quality Management Plan, June 1992. 
steadily increase to approximate the marginal cost of abatement. As emission regulations are tightened, which will occur until the District reaches attainment, the cost of abatement will increase more than geometrically. 48 In all likelihood, ERC prices will reflect this trend.

ERC trading policy also remains an unresolved issue. The primary debate focuses on two major issues: 1) in what units will ERCs be traded, and 2) what structure should be utilized in the formation of the trading market.

It has been recommended by the SCAQMD, and agreed upon by other participating agencies, that ERCs be traded in pounds per quarter. The District felt that annual trading would significantly increase monitoring costs while daily, weekly, and monthly units were unfair to seasonal and cyclical sources whose emissions would differ from period to period. Although not final, quarterly monitoring seems to be the most likely scenario.

As for the market structure, the SCAQMD is far from defining the perfect market system. An analysis of desirable characteristics resulted in the definition of three key areas in which the chosen market system must demonstrate success:

1) Efficiency (internal and external): the cost of assessing the market, successfully completing a transaction, and responding to new information. 2) Information Dissemination: the delivery of timely and accurate information on the price and volume for past and current transactions, and expectations for the future.

3) Liquidity: the ability of the buyer or seller to complete a trade quickly and at a price similar to previous transactions. The depth of trading activity, especially the volume, or number, of bid and offers in a wide range surrounding the prevailing price is also an important element of liquidity. 49

In order to assure that these three criteria are met, the SCAQMD is analyzing the pros and cons of various market systems including: Direct Search Markets, Brokered Markets, Dealer(Quote Driven) Markets, Auction(Order Driven) Markets, and others. NASDAQ, AMEX, PSE, and NYSE are among the specific exchanges being looked at. One facet of the market establishment that has

\footnotetext{
48 The law of diminishing returns dictates that the cost of removing 1 unit of pollution increases as the technology approaches $100 \%$ cleanliness. For example, to reduce emissions from $2 \%$ to $1 \%$ is far more costly than from $10 \%$ to $9 \%$.
}

${ }^{49}$ SCAQMD, RECLAIM, p. 4-11. 
already been agreed upon is that SCAQMD will play as small a role as possible and will seek as few restrictions as possible to insure a free-trade open market.

\section{Utility Planning and FSO4 Environmental Impacts}

The latest round of California resource planning efforts defined the key objectives for future resource allocation decisions: 1) increased environmental quality and 2) fuel diversity. All parties agreed that these two goals are the two most pressing issues facing California's utilities in the immediate future and should be used in evaluating any utility's plan to meet future demands on its systems.

In the past, producers of pollution (including utilities) have not been forced to bear all the costs of their emissions. They have externalized these costs and placed the burden on society. The time has come for utilities to pay their share, although there is much discussion on how big their share is. Nevertheless, California utilities are facing major clean-up cost in the future.

These costs will most likely be passed on to customers in the form of rate increases. One positive aspect of these rate increases is that they will open the door for new alternative energy sources, including co-generators, to enter the market. The FSO4, much like its predecessors $\mathrm{SO} 1$ and $\mathrm{SO} 3$, will be the key instrument in linking these emerging technologies with the utilities transmission monopoly. Furthermore, the FSO4 will offer the opportunity to capture environmental and fuel diversity benefits which the utilities are required to produce.

\section{FSO4 and the Fuel Cell}

The fuel cell may do very well under the $\mathrm{FSO} 4$ co-generation contracting scheme because it has the ability to be considered both a fossil and non-fossil QF. The primary source of fuel to date has been pipeline natural gas, but the fuel cell is capable of operating on any fuel with a methane content of $95 \%$ or more. 50 This means that the fuel cell could operate on biomass produced methane which is a renewable non-fossil resource. In essence, however the final bidding process is set up, the fuel cell will have the flexibility to adjust.

50 Fuel Cell input/Output Model, Dan Kouwabunpat and Jeff Towson, May 1992. 
The reasoning behind choosing environmental quality as a key criteria in resource allocation decisions is quite obvious. Most major cities in California are considered non-attainment areas in respect to federal air quality standards. Because of this fact, the California Clean Air Act requires that local districts reduce emissions of non-attainment pollutants or their precursors at the rate of $5 \%$ per year. 51

Toward this end, districts in California are seeking new, cleaner forms of energy production which will help reduce non-attainment emission levels, particularly NOx. NOx emissions were specifically targeted due to CEC findings that NOx was the only pollutant whose value actually affected the timing of new resources and that it accounted for almost half the total value attributed to residual emissions. 52 The latest figures indicate that this translates to a $\$ 13$ per kilowatt cost for the retrofitting of PG\&E. 53

The reasoning behind fuel diversity is also quite simple. The value of fuel diversity comes from avoiding the risk of relying too heavily on any given fuel. This ensures that fluctuations in supply, pricing, or other aspects of one fuel do not drastically alter or inhibit energy production capabilities.

Fossil fuels, for instance, are not renewable. Their supply is fixed and increasingly harder to extract as time goes on. Once easily recoverable deposits are used, the price of these fuels will increase as expenditures in extraction technology, detection, and other aspects of fossil fuel recovery increase. Another factor to take into account is that much of our fossil fuel supplies are foreign and dependence on foreign supplies of energy, especially in politically volatile areas such as the Middle East is not a wise policy decision.

By shifting focus toward the development of renewable, alternative, domestic fuel sources, we can avoid many of these problems. Developing such fuels will help: 1) to cushion the impact of price shocks on the fossil fuel market, 2) to avoid these shocks by reducing demand and prolonging the life of current supplies, and 3) offer the proper incentives to increase the efficiency and costcompetitiveness of non-fossil technologies.

${ }^{51}$ ER-90, p. 5-4.

52ALJ, 6-5-91, p. 18.

${ }^{53}$ ER-90, p. 5-7,5-8. 
There are two basic ways in which the utilities plan to approach the problem of increasing the number of non-fossil fuel technologies. One is the use of a separate bidding arena for non-fossil QFs. The second is the creation of a nonfossil premium used in the evaluation of non-fossil QFs versus presently used fossil-fired QFs.

The decision on which of these policies, or what combination, to use has yet to be reached. Each involved party has their own ideas on this and the environmental quality issue which they have organized into five major questions which need to be dealt with before FSO4 bidding commences.

FSO4 Bidding and Involved Party Opinions

The five major issues facing $\mathrm{FSO} 4$ bidding are 54 :

1) Should accounting occur through quantitative analysis and/or policy judgments; if quantitative, how should monetary values be derived?

2) Where should accounting be done: in planning, in acquisition of resources, or both?

3) If using monetary values should they be different for projects inside and outside the acquiring utility's service area?

4) Should there be a set-aside separate bidding arena for non-fossil resources, if so, should there be a cap on payment to these QFs over fossil QFs?

5) Should the valuation of utilities and bidders take account of offsets?

Several different responses to these questions were offered by the participating agencies. Few of them agree on any aspect of FSO4 planning. SCE believes that a $15 \%$ addition to cost for fossil QFs and a $15 \%$ reduction for existing site use are the proper incentives. PG\&E recommends that a separate bidding arena should be created for non-fossil QFs with a payment cap yet to be determined. SCAQMD believes that $\mathrm{CO} 2$ emission need to be included in valuation with adders given to clean technologies for price advantage and separate bidding for non-fossil QFs. The Division of Rate Payer Advocates for CPUC believes that non-fossil QFs should receive a $10 \%$ diversity premium and

${ }^{54}$ ALJ, 6-5-91, p. 18-19. 
an adder based on the value of residual emission difference between the utility and the bidder which will be applied to the contract price after the bidder is selected. The ALJ overseeing the debate suggested that a set-aside is unwise because without quantifying the value of fuel diversity a proper set-aside percentage can not be determined. Also, the PG\&E cap proposal is useless if utilities can acquire non-fossil QFs more cheaply and counter-productive if the value of such resources is greater than the cap. 55

The ALJ solution is to create a deferral window through 1999 by which a nonfossil QF must appear under normal bidding for a premium not to be calculated. If one does not appear, the premium will be calculated by replacing the first fossil QF with the most cost effective non-fossil QF. The increase in operating and capital costs caused by the replacement will then be derived in NPV terms expressed as an annualized premium in dollars per kilowatt and will be applied as additional capacity payment to non-fossil QFs. The ALJ also recommended that emission offsets should be included in the resource procurement process because an emission rich technology forced to offset at a ratio of 1.2 to 1 will offer greater environmental benefits than a pollution free technology. This is not very likely since offset prices should reflect marginal emission control costs, but the option must be left open. 56

\section{Implications for Fuel Cell Viability}

The introduction of PURPA fostered the growth of many new co-generation projects. Fuel cell projects can currently capitalize on the many advantages of PURPA through the sale of excess electricity to utilities. As Qualifying Facilities, fuel cells may be able to generate revenue streams from electricity sales. Currently fuel cells can only sell power on an "as available basis". This is done through either signing a Standard Offer contract with one of the basin utilities. The emergence of long term, firm capacity contracts (FSO4) will provide fuel cells with a more secure, potentially profitable option for future power sales. The CPUC has begun to solidify the new QF market in hopes of encouraging new technologies such as the fuel cell. The Commission has forced utilities to provide backup power for new technologies at "reasonable rates" as well as assistance in interconnection planning and financing. Furthermore there seems to be a trend toward greater reliance on Qualifying Facilities such as the fuel cell in the future. Power sales to utilities can currently provide fuel cells with a substantial new revenue stream. Although economic viability of the fuel cell is

${ }^{55} \mathrm{ALJ}, 6-5-91$, p.21-24.

${ }^{56} \mathrm{ALJ}, 6-5-91$, p. 34-35. 
dependent on many variables, legislation such as PURPA, in conjunction with strong CPUC support, increases the overall economic feasibility of fuel cells.

Probably the most important emerging regulation to fuel cell viability is expanded grid access and wheeling rights for IPP's and QF's. Such changes will raise buyback rates. QF's like the fuel cell will be able to sell excess electricity in a more open market, reducing the utility's current monopoly. The current 9 cent price anomaly in the energy market will be significantly reduced. The CPUC will force electric utilities to set "fair" wheeling and interconnection rates. 
All model scenarios included in this attachment used the following constants in the Cost of Ownership Model.

BTU per kilowatt hour

Watt*hr per BTU

0.2929

BTU per refrigeration Ton Hour

12,000

Pounds per Gallon of Water

8.33

Ratio of Thermal Energy Produced to Electrical Energy

Ratio of Fuel Consumed to Elecrical Energy, SCF/kWhr

4250

Boiler Efficiency, Ratio of Output Energy to Input , DMLS

9.5

Heating Value of Natural Gas, BTU/SCF, HHV

0.9

Winter Seeeason for Heating and Off-Peak Electric Rates

1000

Summer Season for Cooling and On-Peak Electric Rates

Levelized Capital Cost Facot, DMLS \% of Capital Costs

119

Local Industrial Property Taxes, \% of Depreciated Capital

Federal Income Tax Depreciation Life in years

$10 \%$

$2 \%$

20

Discount Rate \%

\section{Scenario Set A}

Compares the cost of ownership of a fuel cell operating continuously at full capacity with an office building demand operating only 6 days a week and 12 hours per day.

Case 1- Office Building Operation Continuously

Case 2- Office Building Operating 6 days a week for 12 hours each day.

\section{Scenario Set B}

Cases illustrating the imapct of four rate schedules on contstant demand fuel cells of varing capacities. The four rate schedules are Southern California Edison Schedules TOU -8, TOU-GS, GS-2, and Standby (Schedule S).

Case 1 - Office Building in constant operation with Fuel Cell Capacity of $200 \mathrm{~kW}$

Case 2 - Office Building in constant operation with Fuel Cell Capacity of $400 \mathrm{~kW}$

Case 3- Office Building in constant operation with Fuel Cell Capacity of $600 \mathrm{~kW}$ 
Case 4 - Office Building in constant operation with Fuel Cell Capacity of $1000 \mathrm{~kW}$

Case 5 - Office Building in constant operation with Fuel Cell Capacity of $1500 \mathrm{~kW}$

Scenario Set C

Cases illustrating operation of large office buildings at the lowest energy rate and highest demand charge category.

Case 1 - Office Building daytime operation with Fuel Cell Capacity of $550 \mathrm{~kW}$

Case 2 - Office Building daytime operation with Fuel Cell Capacity of $1100 \mathrm{~kW}$

Case 3- Office Building daytime operation with Fuel Cell Capacity of $2000 \mathrm{~kW}$

Case 4 - Office Building daytime operation with Fuel Cell Capacity of $3000 \mathrm{~kW}$

Case 5 - Office Building daytime operation with Fuel Cell Capacity of $4000 \mathrm{~kW}$

\section{Scenario Set D}

Cases illustrating the economics of food production operations with a ratio of thermal to electric peak load at .65 or greater at varing fuel cell capacities.

Case 1 - Food Producer with Fuel Cell Capacity of $200 \mathrm{~kW}$ Case 2 - Food Producer with Fuel Cell Capacity of $385 \mathrm{~kW}$ Case 3- Food Producer with Fuel Cell Capacity of $730 \mathrm{~kW}$ Case 4 - Food Producer with Fuel Cell Capacity of $1460 \mathrm{~kW}$ Case 5 - Food Producer with Fuel Cell Capacity of $2000 \mathrm{~kW}$

Scenario Set $E$

Cases illustrating the economics of varing initial capital cost for an installed fuel cell on the demand profile of a mult-unit residence or institution, such as a small hotel. 
Case 1 - Multi-Unit Residential Hotel or Institution with Fuel Cell Capacity of $200 \mathrm{~kW}$ and Capital cost of $\$ 1200$

Case 2 -Multi-Unit Residential Hotel or Institution with Fuel Cell Capacity of $200 \mathrm{~kW}$ and Capital cost of $\$ 1600$

Case 3- Multi-Unit Residential Hotel or Institution with Fuel Cell Capacity of $200 \mathrm{~kW}$ and Capital cost of $\$ 2000$

Case 4 - Multi-Unit Residential Hotel or Institution with Fuel Cell Capacity of $200 \mathrm{~kW}$ and Capital cost of $\$ 2000$

Scenario Set F

This case illustrate the economics of operating a $200 \mathrm{ME}$ fuel cell to generate electric power for sale under the provisions of Final Standard Offer 4 . The Fuel Cell is assumed to operate at 73 percent available time.

Case 1 - A $200 \mathrm{~kW}$ fuel cell operating at 0.73 of capacity with private ownership, paying taxes on revenue and receiving both environmental and tax incentives. 



\section{A Model of the Cost of Ownership of the Natural Gas-Fired Fuel Cell}

The natural gas fired-fuel cell was first technically proven as a source of electrical power and potable water in the U.S. Space program of the 1960's. Since then the government and private industry have invested hundreds of millions of dollars to "finish the development" and bring the product into the commercial marketplace. This report on the Economic Feasibility Analysis of Distributed Electric Power Generation based upon the Natural Gas-Fired Fuel Cell is a examination of the economic factors of fuel cell ownership by several classes of individual owners. There is extensive literature and analysis of fuel cell ownership by utility electric generators (UEG) so this report does not consider the economic factors of ownership by regulated UEG's. The analysis is not an "Estimate" of fuel cell costs, but an analysis of the circumstances of ownership and how changing circumstances might lead to broader applications of the technology without advances in the state-of-the-art. In selected applications the currently available cell can offer a economical alternative to the purchase of power and thermal energy from the local utility.

The major circumstances considered in this analysis that led to the conclusion that distributed power generation with the fuel cell was viable are summarized below.

- The fuel cell has a substantial advantage over other generation technologies in matching the demand of an application to the fixed capacity of the fuel cell. The fuel cell has excellent part power performance. This permits operation during low demand periods without increasing operating and maintenance or energy costs per $\mathrm{kW} / \mathrm{hr}$. However, applications with very low effective capacity cannot sustain high capital costs of a system that operates as little $35 \%$ of the time (Retail, Offices, Entertainment Industries. This market will remain limited until the regulations that define "public utilities" or how capacity may be shared are modified.

- Fuel cell-based central utility plant systems, sized to meet the peak electrical demand of an application with an effective capacity as low as $55 \%$ of nameplate, can have a lower cost of ownership than the purchased power alternate. However, the currently available cell is only available in a single capacity and the physical packaging is inflexible. A modular design, that expands over a range of 200 to $2,000 \mathrm{~kW}$ will have a substantially larger market. Industrial boilers are effectively available in any capacity despite the relatively lower capital cost and smaller "penalty" of unused capacity. 
- The variation in an application's demand for thermal energy is readily manageable. Excess thermal energy produced during off-peak hours and be saved and used to meet peak consumption demands. Thermal energy production considerations should not drive fuel cell sizing considerations. Even though about half of the useful energy produced by the fuel cell is in the form of thermal energy the value of that energy is only $10 \%$ of the value total energy produced.

- All of the economic benefits, of $80 \%$ efficient energy conversion can be captured by considering the fuel cell as an element in a larger plant system. Potential applications that use or plan to use a hydronic system for space conditioning are most likely to fully utilize the energy conversion capacity of the fuel cell. A second important use of the thermal energy from the fuel cell is air-conditioning that utilizes an absorption chiller in association with the hydronic distribution system. The economy-of-scale of larger absorption systems, combined with their lower operating costs, can make absorption chilling the most economical space conditioning system and improve the economics of the fuel cell.

- Energy planners in many of the major metropolitan areas have abandoned the capacity expansion option that requires construction of large, centrally located, power generation stations. They are depending upon re powering existing facilities, renewable resources, and fuel cells to supply future capacity ${ }^{1}$. The same planners are recognizing the societal cost of providing this capacity. They are requiring that the price of electricity include penalties (reductions in allowable rates) for emissions of category air pollutants. The penalty levied against conventional generating technology becomes a benefits for the ultra-low emission fuel cell. The benefit can amount to $18 \%$ of the present value of the fuel cell investment, or $\$ 0.013 / \mathrm{kWhr}$.

- An important group of potential fuel cell owners/users are constrained from considering an investment in a fuel cell by existing utility regulations. In California and several other states if the fuel cell owner sells electricity to more than one customer ( in addition the their local utility) they will be considered a regulated utility. The only relief from this restriction is in a situation where the power is not metered. If the restriction were relaxed The owner of an office building or a shopping center could rent space with "utilities included" and meter the power to avoid inequitable power consumption by some tenants.

\footnotetext{
'The South Coast Air Quality Management District and the Califomia Energy Commission recognize that about 10,000 Megawatts of additional generating capacity will be required in the basin, just to meet the demand of clean air measures. All of this capacity growth is planned from small"unconventional sources, including fuel cells. Source: Air Quality Managenment Plan, 1989 and 1992.
} 
This model of the cost of fuel cell ownership combines the product of the capital cost model, ownership scenarios and the operations model revenue streams to compute the cost of ownership. The form of the output is user selectable from a menu that includes cash flow curves, net present value as a function of capital cost and fuel cost or the internal rate of return on investment.

Approach

Before calculating the economic benefits or cost, the ownership profile must be defined. The fuel cell application to be evaluated must be characterized in both engineering and energy demand terms. The estimated electrical and thermal demands of the application along with the physical systems configuration must be selected for the case to be analyzed. In addition, the type of owner should be known. For example, if the owner planning to consume all electrical and thermal energy or distribute ( or 'Wheel") a portion of the capacity to other users. This information will guide selection of the appropriate model elements.

\section{Ownership Model Assumptions}

The Combined Use Survey defines the ownership energy consumption characteristics considered by this analysis. The survey defines the consumption characteristics of users with the greatest potential to benefit from employing fuel cell technology. Potential distributed fuel cell applications considered by this analysis comply with the following profile:

- average electrical load greater than $200 \mathrm{~kW}$

- average thermal energy load greater than $250 \mathrm{~kW},(853,000$ BTU/Hr)

- the ratio of thermal load t electrical load greater than 1.25:1.

- manageable demand variation, or

- co-located with a other consumers so that the combined energy load profile meets the above criteria.

For purposes of developing the ownership model, the combine use data defines three primary user classes.

- Class 1 - Large multi-story building with residential characteristics. Class I includes hospitals, hotels and prisons.

- $\quad$ Class II- Industrial applications which consume energy at a relatively constant rate in three shift operations. Class III includes food processing plants and health clubs. 
Class III - Multi-unit Professional or retail applications characterized by 12 to 16 hours of operation per day. Class III includes office buildings, retail stores and shopping malls.

In order to provide flexibility in defining the ownership profile, the Cost of Ownership Model includes a fourth class of user.

- $\quad$ Class IV - User defined application based upon the demand profiles in the Combined Use Survey or other source. Class IV can be any combination of the first three user classes, or a hypothetical application to "test" the economics of the application.

Class IV is to be used when the fuel cell application under study does not fit any one of the first three classes. The model provides a means for the analyst to define the energy demand and systems capacities.

Capital Investment Assumptions

The study considers the economic viability of a distributed fuel cell system to be the same as a major capital investment decision. To the potential owner, the distributed fuel cell investment must make business sense. In this context, if the net present value of the investment and revenue stream associated with a distributed fuel cell application over a given operational period is positive, the application is economically viable. If the net present value of the fuel cell investment is at least $\$ 1$ more than the alternative of purchasing electricity and thermal energy from other sources, then the distributed fuel cell application is economically viable, and therefore a good business decision.

However, the question of the cost of ownership over a period of time is a function of several factors and may be influenced by the assumptions on with the distributed fuel cell application is based. The cost of ownership model provides an estimate for the capital cost, the environmental incentives, the operations and maintenance cost and the potential revenue of three classes of fuel cell application. Since there are few statistics on the number of fuel cells sold, and on fuel cell operations cost or operational reliability, structuring the economic analysis as a capital investment decision requires several basic assumptions.

First, the analysis assumes that there is a commercially available fuel cell and that the number of fuel cells in use will increase. This assumption is fundamental to the analysis because without a commercial supply of fuel cells which are reliable and can be operated over an extended period of time, the technology will not become economically viable. On the basis of this 
assumption, the model estimates future manufacturing and installation costs by adjusting current Harare and installation costs using a learning curve.

Second, the analysis assumes that the fuel cell capacity may be adapted to fit the application's demand. The modifications in the central utility plant capacity based upon the demand profiles is based upon this critical assumption . Currently, the only commercial fuel cell is manufactured in one size, $200 \mathrm{~kW}$. The economic analysis assumes that as the demand increases, the one size only limitation will be over come.

Third, the model assumes that the manufacturer's specifications for operations and maintenance are achievable and realistic. The analysis accepts the maintenance periods represented by the fuel cell manufacturer and uses the reliability projections and the operational hours before major overhaul to structure the maintenance cost estimates.

Fourth, the analysis assumes that the barriers to permitting and licensing fuel cells will be eliminated as the market grows. Currently, the fuel cell installations in California are proving to be prohibitively expensive due to a protracted licensing and permitting cycle. The layers of local and state permit authority create an expensive review cycle that if continued, will add a significant cost burden to the ownership of a fuel cell. This assumption allows the economic analysis to consider the consecution of fuel cell system to be no more complex than any commercial alternative for electrical and thermal energy.

Fifth, the analysis assumes the fuel cell could be eligible for environmental credits in certain ownership scenarios. The economics of the distributed fuel cell are enhanced if environmental benefits are considered. The low emission characteristics of the fuel cell provide it with a significant competitive advantage over electricity produced by engines, turbines and central utility power plants.

\section{Fuel Cell Physics and Capital Costs}

There are several different fuel cell technologies not in development or entering the early states of commercialization. The principle of operation is the same for each type. A natural or synthetic gaseous fuel comprised mainly of methane is reformed over a catalyst with high temperature steam to produce hydrogen and carbon monoxide. The carbon monoxide is further reacted with water to produce additional hydrogen and carbon dioxide. The hydrogen is reacted with oxygen from the air in an electrolyte to produce and electron flow, hot water or steam and carbon dioxide. the principles of operation of each type of fuel cell are the same. They only differ in electrolyte material and operating conditions. 
The Central Utility Plant Model establishes the technical characteristics of a central utility plant configuration appropriate to the distributed fuel cell applications under study. The central utility plant design is conceptual and does not include all engineering detail necessary for construction. The intent of the central utility plant design is to provide a vehicle for studying the economics of a distributed fuel cell.

The fuel cell oriented plant design is based upon conventional heating and cooling plant configurations. The conventional central utility plant design adopted for this analysis uses combustion energy to supply space and water heating. It provides chilled water for space cooling from an electrically powered centrifugal chiller and distributes the electrical energy supplied by the local utility. The conventional pant heating system is designed to serve a hydronic four pipe thermal distribution system that supplies heat transfer fluid to a fan-coil space conditioning heat-exchanger. Thermal energy is supplied to the space heat system by a gas fired boiler or fuel cell and to separate potable water system through a heat exchanger. The fuel cell based central utility plant is similar to the conventional system. Both systems are designed to deliver hot and chilled water to a hydronic, four pipe thermal distribution system. Both designs segregate the potable water system from the water used as the heat transfer fluid, which requires a secondary heat transfer loop. the primary differences between the conventional central utility design and the distributed fuel cell central utility plant design are : (1) the fuel cell is the primary source of electrical and thermal energy, (2) a larger hot water storage tank to provide thermal backup; (3) the substitution of an absorption chiller for the electric powered centrifugal chiller; and (4) an additional heat transfer loop to supply hot water or steam to the chiller.

\section{Capacity and Demand Matching}

The central utility plant element of the model computes the capacity of each fuel cell plant element based upon the class of application, or the user defined requirements for production of electrical and thermal energy developed from user selected demand schedules. Thermal energy produced and natural gas consumed by the distributed fuel cell systems configuration are calculated from their relationship to the electric power produced; along with the size of the ancillary equipment in the systems configuration.

The model sets the fuel cell capacity to satisfy the user specified peak electrical demand. The capacity best suited for an application depends upon the application demand profile, the cost of replacement electrical power, the potential revenue from sale price of excess electric power, and the capital and operating cost of the system. 
The model computes the electrical power produced by the fuel cell by scaling the demand profile by the user input peak demand. The natural gas consumption and the thermal energy produce are computed as dependent variables of the electrical power produced. The fuel cell output is reduced during off peak periods by modulating the gas supply. This results in a "demand" matching model of the fuel cell size to systems operation.

The capacity of the remaining elements of the central utility plant model are competed from the thermal energy produced by the fuel cell and the air conditioning and heating requirements of the system.

\section{Thermal Energy Utilization}

The thermal energy distribution system transports the thermal energy produced in a central utility plant fuel cell system to the point of use. Typically, this systems consists of a network of piping or ducts that transport the thermal energy for space conditioning, process heating, or process cooling purposes. The model sizes the auxiliary boiler to produce the thermal demand of the application as a backup. The boiler is sized to meet the chiller requirements. The model default boiler efficiency is 90 percent. A different efficiency may entered by the analyst.

The thermal demand may be smoothed by a thermal accumulator. During the peak hours of thermal use, the thermal energy is supplied from the stored hot water tanks. The excess thermal energy produced during off-peak periods is stored in the thermal accumulator tank for use during peak demand periods. The volumetric capacity of the tank is computed as the volume required to store the difference in energy between the daily average thermal demand and the peak demand. the energy is computed as the product of the fuel cell delta temperature and the weight of the water in the tank.

The systems cooling tower is sized to reject the thermal energy absorbed by the absorption chiller plus the energy transferred into the absorber concentrator loop. The fuel cell installation also requires a back-up method to reject the thermal energy produced in the event of failure of the heat transfer equipment.

\section{Fuel Cell Capital Costs}

The capital cost of the fuel cell is the estimated cost of the hardware based upon the size of the system and the number of systems in use. The model requires an estimate of the number of the fuel cell installations in order to predict the appropriate position on the learning curves for both the fuel cell manufacturing and the fuel cell installation. The fuel cell capital equipment estimate includes the fixed hardware cost, the cost of installation and of systems start-up. 


\section{Balance-of-Plant Costs and Benefits}

For the balance of plant equipment, the per unit cost is estimated by multiplying the capacity of the unit by a cost factor. The cost factor is a linear regression expression of the capacity of each hardware element and the published cost of the unit in 1992 dollars. The cost relationships for each type of equipment are derived by correlating the per unit cost to the equipment capacities or output. The per unit costs include acquisition of hardware, use taxes, transportation, site engineering, ancillary equipment, installation labor, and the necessary permits and fees.

\section{Environmental Benefits}

In certain ownership situations the fuel cell may benefit from environmental incentives or air quality offsets. In southern California, the South Coast Air Quality Management District (SCAQMD) does not regulate emissions from fuel cells or boilers with a thermal input less than 2 million Btu. The heat input of a $200 \mathrm{~kW}$ fuel cell is 1.9 million Btu. Although the technology has not yet been restricted by regulations or included as a candidate for emission credits, it is within the range of sizes that have been addressed by regulators. Furthermore, a recent California Law Judge ruling will require a utility to pay an additional allowance for the purchase of electricity from clean sources.

The cost of ownership analysis may elect to include a stream of benefits due to emission credits for NOx, SOx and ROG to evaluate the effect on the economics of the enactment of regulation involving fuel cell technology. These potentially could include Utility Displacement Credits (ADC's) for displacing the need for operation of a portion of the utility's generating capacity. The model computes the value of the credit by multiplying the current year's permitted emissions in pounds per MeW hour times price per ton for the criteria pollutant time the annual fuel cell electrical production. The fuel cell owner would be entitled to an Emission Reduction Credit (ERC) in the amount of the emissions of a piece of equipment replaced (or retired) by installation of a fuel cell. The credit can be applied to other equipment at the facility or may be traded or transferred to offset emissions at other installations operated by the fuel cell owner. Additionally, credit for thermal energy produced may be traded or sold at a price approaching the California Public Utility Commission (CPUC) abatement expense estimates for the category pollutants.. The model computes the value of the ERC from the amount of the previously permitted emission time the price of the criteria pollutant. As of this writing 17 of the 50 states have similar proposal for credits or allowances for purchase of electricity from "clean sources" under various stages of development and implementation. 
Ownership Model Component Descriptions

Model User's Input Module

The model user is part of the Excel workbook that contains the model. The input module is located in the spreadsheet "model". It is used to specify the class of ownership and the peak electrical load in $\mathrm{kW}$. For demand situations that do not fit one of the pre-defined classes, the analyst may enter a set of 24 values for hourly electrical demand in $\mathrm{kW}$ and thermal demand in 1000 Btu per hour. The model computes the demand schedule and estimates the fuel cell capacity and systems size from these data.

\section{Thermal Energy Distribution System Model}

The model estimates the capacity and output of the. thermal energy distribution element of the fuel cell system based upon the class of the application and the configuration of the central utility plant model. The model specified (default) thermal energy configuration contains water storage tank, an absorption chiller, heat transfer looping, an auxiliary boiler and a cooling tower. The thermal energy produced by the fuel cell and the thermal energy demanded by the class of application are the basis for estimating the size and capacity of the these elements of the system.

For situations that do not fit one of the pre-defined classes, the analyst may define the boiler capacity, air conditioning chiller capacity, the thermal accumulator tank capacity, the cooling tower capacity, and the space cooling and heating pump capacity. The model computes the demand schedule and estimates the fuel cell capacity and systems size from these data.

\section{Central Utility Plant Model}

The central utility plant model computes the capacity of each fuel cell plant element. The capacity for the fuel cell production of electrical and thermal demand energy is developed from the user selected demand schedules and scaled to the appropriate load by peak demand. The model user specifies the energy consumption class and the peak electrical load in $\mathrm{kW}$. The model also provides for demand situations which do not meet the pre-defined demand profiles. A Class IV user profile is defined by the user by entering a 24 hour set of values for the ratio of the current demand to the peak demand. The actual electrical demand in $\mathrm{kW}$ and thermal demand in 1000 Btu per hour are scaled from this profile by the user entered value for "Peak Load." 


\section{Capital Cost Model}

The capital cost model uses the systems capacity parameters defined in the Central Utility Plant model to estimate the cost of acquiring and installing the fuel cell system. The capacity parameters are defined by the class of the fuel cell system selected at the model set-up. For plant configurations that do not fit one of the pre-defined classes, the analyst may enter a set of values for fuel cell, the boiler, the air conditioning system, the hot water storage system, the cooling tower and the associated system pumps and miscellaneous hardware. Once the hardware sizes are defined (either by the model or the analyst) the cost of the capital equipment is computed by applying a cost factor to the capacity of the system hardware. The cost factors are part of the model and are developed by linearly regressing capacity values for each hardware element and the published cost of the unit in 1992 dollars.

\section{Operations Model}

The model accounts for the sources or avoided costs and uses of funds for the operation of the plant as well as potential revenue from sale of excess power and thermal energy and environmental or regulatory offsets. The benefits of each stream of material or energy that enters or leaves the plant are computed form the capacity information computed by the Central Utility Plant Model. The operating costs of the central utility plant include the natural gas purchased for fuel. The quantity of gas is computed as a function of the electricity produced by the fuel cell. Back-up fuel is computed as the ratio of winter days per year times the fuel cell availability.

As part of the model setup, the analysis selects the source of electricity purchase price and price growth, the price of natural gas and gas price forecast, and the incentive benefits included in the analysis. Default operations and maintenance costs are defined by the model based upon the class of fuel cell installation. From these data, the model computes the cost of natural gas, avoided electricity costs and the environmental incentives associated with the distributed fuel cell installation.

For situations that do not fit one of the pre-defined classes, the analyst may define the electricity rate and electricity growth rate as well as the price of natural gas and the incentive benefits to include in the analysis.

Model Output Summary

The ownership summary model is brief synopsis of the results of a single case input and output for all elements of the model and the presentation of 
interdependent results. It includes the fuel cell user class and its electrical and thermal demand characteristics. The physical configuration of the fuel cell and its balance of plant and their capital costs are also included. The summary output data are located on the spreadsheet "Model" immediately following the input section.

The summary model output includes the operating costs and benefits and their present value over the planning horizon. The benefits include a summary of the operating incentives including emission offsets and displacement credits that have quantitative value. Parametric values of other more subjective benefits could not be included because there was no industrial consensus on either their quantitative values or even the elements that might be included.

\section{COST-OF-OWNERSHIP ANALYSIS RESULTS AND DISCUSSION}

\section{Capital Costs and New Technology}

The first question that any potential fuel cell owner will pose is, How Much? There in now only a single model of commercially available fuel cell, made by one manufacturer. The first few examples of this system have been in operation less than a year. In many cases the first costs, site preparation and installation were partially sponsored by the local utility. Consequently the answer to the "How Much" is not clear and perhaps not as important as a knowledge of the cost of the system once the manufacturer has begun to produce in sufficient quantity to benefit (and price) from his experience rather than estimates.

Figure 2 is a graphic representation of a manufacturing learning curve. The curve reflects how the price of an article in "mass" production can be expected to fall as the manufacturer gains experience.

Figure 2

Manufacturing Rate

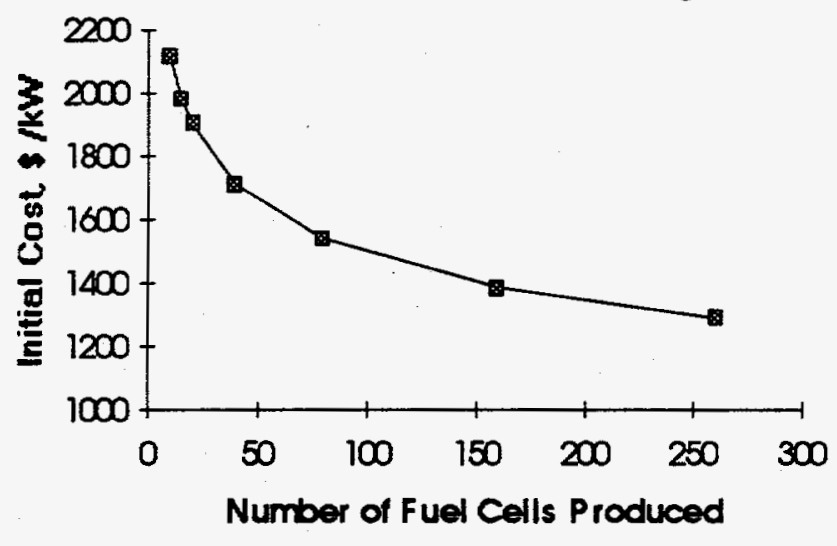


The example chosen reflects a drop of $10 \%$ ( $90 \%$ learning) for each doubling of the quantity of product made. Manufacturing learning on a mature product is less significant; manufacturing specialists are pleased with 95 to $98 \%$ learning rates. Manufacturing costs of a brand new product will fall at an 80 to $85 \%$ A learning value of $90 \%$ was chosen for most of the parametric studies in this report as a "conservative" value that should be readily achievable on this new technology.

As illustrated in Figure 2. the initial commercial version of the fuel cell is being marketed for about $\$ 2500$ per $\mathrm{kW}$. Those in the electric utility electric industry that follow fuel cell technology will insist that this source of power should be sold for about $\$ 1000$ per $\mathrm{kW}$ "to be economically viable."

Figure 3

Economically Feasible Fuel Cell Cost

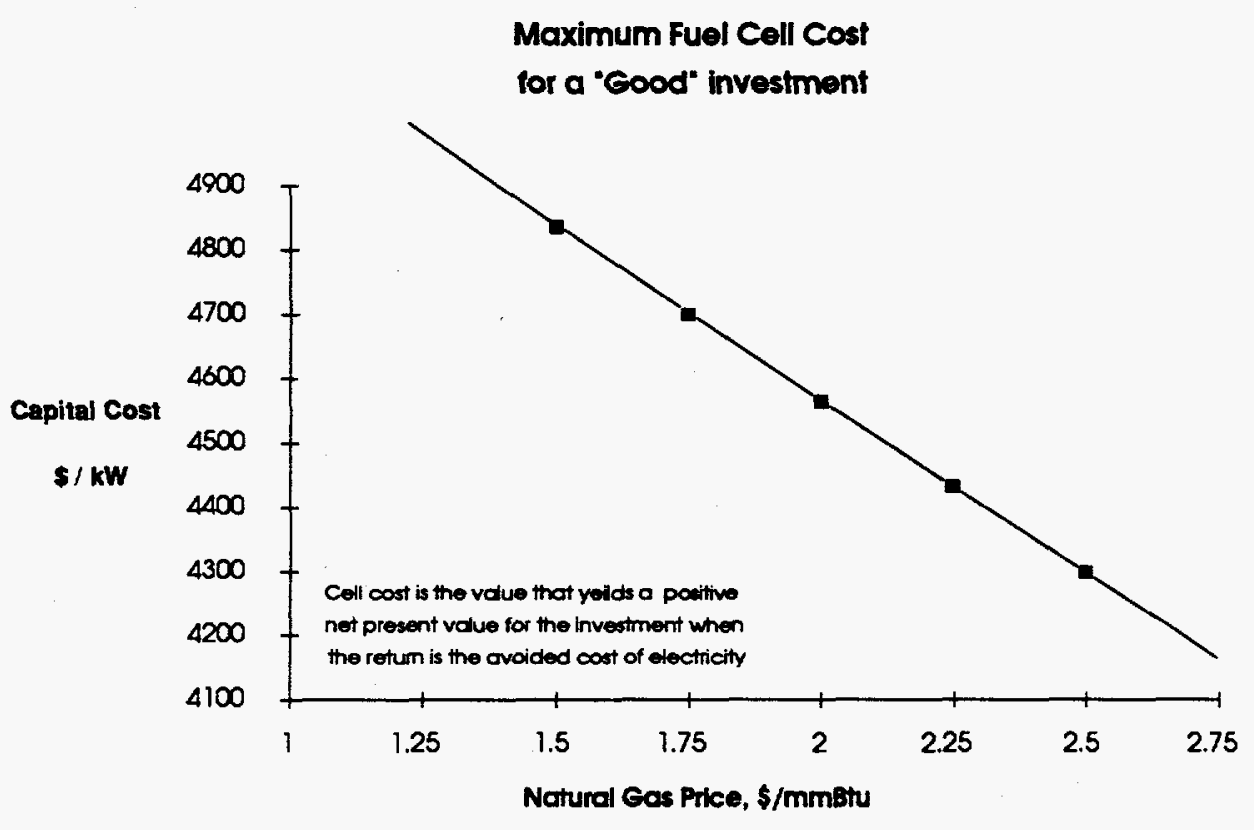

The characteristics of an economically viable investment for the utility industry may not be the same for all industries. Figure 3 is an illustration of the "afford ability" of fuel cell technology without the bias of an industry's preference. In non-compliant air basins, electrical generating utility are planning on "re 
powering" their existing capacity with gas turbines. Their estimates 2 of the cost of replacing less-efficient combustion turbines range between 550 to $950 \$ / \mathrm{kW}$. These projects are frequently hundreds of megawatts and do not include the cost of site preparation or the balance of plant. A much smaller, self-sufficient power plant initially priced at $\$ 2,000$ to $\$ 2,500$ per kilowatt seems reasonable when the cost of the equipment can be expected to drop dramatically as the market expands, and manufacturers apply their experience to reduced manufacturing cycle time and costs.

The potential owner is interested in the value of the investment in the fuel cell. An answer to the investment question can formed by computing the maximum first cost of a fuel cell to ensure that the net present value of the investment remains positive over the expected range of operating costs. Figure No. 3 . Is a plot of the net present value of the capital cost of a fuel cell in $\$$ per $\mathrm{kW}$ and the stream of payments for electricity generated by the cell over a range of prices for natural gas. The value of the stream of cash generated by avoided electricity purchase is over $\$ 4,000$ per kilowatt at current annual average electrical rates. Many industries are pleased with such an investment whose present value may be is twice the capital cost.

\section{Fuel Cell Capacity and Owner's Electrical Demand}

An important resource management challenge in the utility electric generation industry is matching the capacity of available generating resources to the demand for power. This consideration becomes even more important to an individual owner who does not have the diversity of uses for power of a massive electric grid and yet cannot afford to be without sufficient power. Such an individual user has three choices when selecting the capacity of their generating plant.

- Size the plant to just satisfy the minimum demand of the application to permit operation of the facility at $100 \%$ capacity full time. The difference between minimum and peak load can be purchased from the utility. This will leave most commercial and industrial users with an electric bill that is only slightly smaller than if they had not invested in a fuel cell. The minimum electrical demand for this class of users is at most $20 \%$ of their peak demand and generally occurs during off-peak hours. The cost of electricity for "time of use" customers during these periods is only about $1 / 3$ the cost of power during peak periods. The potential fuel cell owner/user could avoid only

\footnotetext{
2 The Southern California Edison estimate of the cost of repowering 274 megawatts of the San Bernadino $1 \& 2$ generating station is $\$ 630$ per $\mathrm{kW}$. Reference: the "Southern California Edison Company Request for Bids for Qualifying Facility Electric Generation Resources"
} 
about 5 to $7 \%$ of their annual power bill by substantial capital and fuel cell operating costs.

- The plant could be sized for near peak demand and the excess capacity sold back to the utility under an "as-available capacity" contract avoiding an idle capital investment during off-peak demand periods. Unfortunately the utility doesn't need the power then either. The fuel cell owner may be able to contract for power sales at an "energy only" price. The owner would not be entitled to energy related capital costs (ERCC) or a "shortage cost" since they could not dedicate an "uninterruptible" fraction of their capacity to the utilities use. The "energy only" price is based on the utilities cost of natural gas. Normally their cost is substantially less than a "small" industrial customer will have to pay. Under this scenario the fuel cell owner could not recover the cost of the fuel needed to generate the electricity sold to the utility, much less recover a portion of their capital cost or the operating costs unrelated to fuel.

- The economically preferred fuel cell sizing/operating policy is to design the cell to meet the users peak demand. During off-peak periods the cell is operated at reduced power, thereby conserving fuel and avoiding the variable maintenance costs that are proportional to power produced. As long as the lost opportunity cost of the idle capital investment is smaller than the avoided cost of purchased power the investment is sound.

The selection of the capacity of the fuel cells for the applications considered in the analyses in this report are based on preceding logic and the physics of the fuel cell. As an electro-chemical process the fuel cell's "turn-down" ratio 3 is better than any other currently used electrical generating technology. Unlike combustion turbines, steam turbines or internal combustion engines the fuel cell efficiency is almost unchanged down to 25 or $30 \%$ of design capacity.

Figure 5 is a dimension less plot of a phosphoric acid fuel cell electrical and thermal output as a fraction of energy input. The process stiochemetry for a molten carbonate electrolyte fuel cell and the solid oxide fuel cell are identical to the phosphoric acid electrolyte fuel cell. Therefore the performance of these newer technologies should be similar at part power.

\footnotetext{
3The "turn-down" ratio is the ratio of the efficiency of a device operating at part power to the efficiency of operation at its design point or $100 \%$ of nameplate capacity.
} 
Figure 4

Fuel Cell Performance Model

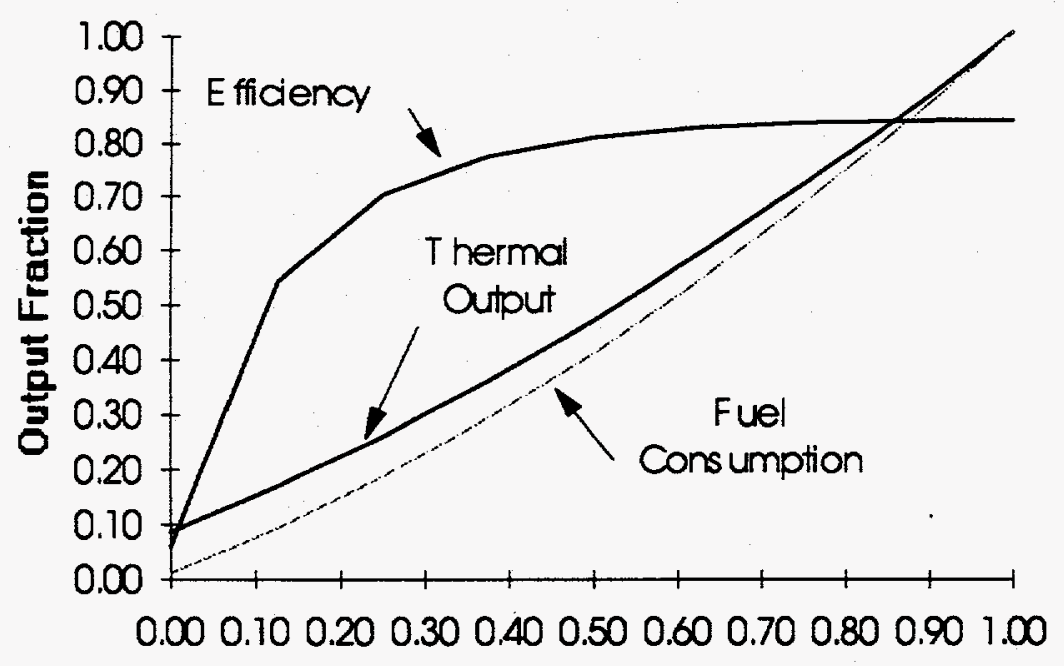

Fraction of Design Demand

The high turn-down ratio of the fuel cell makes it effective in most "real" applications that do not always operate at full power. The net present value of the fuel cell is positive for most of the users surveyed. In applications where the effective capacity 4 is as low as $50 \%$ the system is still cost effective. Fuel cells installed for Class III users; offices, schools and retail enterprises that operate fewer than 10 hours per day and only six days per week might have an effective capacity of only $25 \%$. Such users are not cost effective 5 applications of fuel cells unless the entire space conditioning load can be shifted to thermal energy (adsorption cooling) 6 .

\section{Modularity}

The unusual operational flexibility of the fuel cell cannot accommodate seldom or never used capacity. As described in the Ownership Model Assumptions the functional model of the fuel cell was assumed to be completely flexible, without step changes in capacity as commonly found in lower cost industrial equipment. The assumption was made in the light of the currently high first-cost of the initial models of the fuel cell. The assumption is necessary and future offerings of the

${ }^{4}$ Effective Capacity is defined as the ratio of electrical power produced to the nameplate electrical capacity of the generator.

${ }^{5}$ Appendix 2 Model Case Study No. 3. Large Office Building

${ }^{6}$ Appendix 2 Model Case Study No. 4. Absorption Cooling 
technology must be available in small increments of capacity if small distributed power plants are to be economically viable in most industrial applications.

Fuel cell technology is inherently suited to applications that require a broad range of generating capacity comprised of small increments. The two principal elements of capital cost of the fuel cell are the electrochemical cells themselves and the $D C$ to $A C$ electrical power conversion equipment. The fuel cell system is comprised of hundreds to thousands of cells arranged large series/parallel arrays. An electrical schematic might resemble a battery energy storage facility because of the similarity of the basic system element, the electrochemical cell. The maximum electrical drop across a fuel cell or a battery cell is about 1.5 volts, consequently a complete cell system has hundreds of cells is series. Each series chain has only a few amperes of current carrying capacity. Thus, the design could be comprised of a number of "building blocks "of capacity as required to deliver the required capacity.

The static power converter is also well-suited to modular design . The principal solid state device (transistors) used have similar limits on their maximum voltage drop and current capacity. This characteristic is reflected in designs that are large series/parallel arrays. As a result, the design capacity of power conversion equipment is variable in small increments and manufactured and marketed accordingly.

\section{Thermal Demand Smoothing}

The process of selecting fuel cell capacity is principally based upon the application's demand for electrical energy. Thermal energy is also important to the user and a significant element of the cost-of-ownership. The fuel cell produces an "extra" $1.25 \mathrm{kWhr}$ in thermal energy for each kWhr of electrical energy. However, thermal energy utilization does not drive the sizing process. The economic replacement value (a boiler and natural gas fuel) of the thermal energy produced is only $11 \%$ of the total energy produced by the fuel cell. If the application requires additional thermal energy the fuel cell output can be readily supplemented by an auxiliary boiler.

Daily (or week-end) swings in thermal demand can be economically smoothed with a large hot water storage tank or accumulator and need not be considered when the fuel cell operational policy is set. The central utility plant model compensates for thermal energy shortfalls by increasing boiler fuel gas consumption. The accumulator is used to smooth thermal demand peaks in residential applications. In these applications there are large surges in thermal energy (hot water) demand for bathing and cooking early in the morning and late in the evening. The tank should store the difference between the average and 
the peak thermal energy consumption. The average to peak ratio for residential applications is about 0.7 .

A tank to average the thermal demand for a small hotel will hold about 2,000 gallons and 1.7 million Btu. If all of the energy is recovered every day the present value of the energy savings is $\$ 25,000$ from a water tank investment of $\$ 18,000$ The accumulator also simplifies energy management and fuel cell controls.

The Fuel Cell as a System Element

A major class of potential users are unable to explain the advantages of distributed power generation because of the characteristic of their energy consumption patterns. The Class III users were characterized in the Combined Use Energy Survey 7 as operating during the day for 10 or 12 hours, five or six days per week. Retail establishments, schools and office buildings all fall into this class. The electric demand of such a user is constant at the peak load for the period of operation and drops to 15 to $20 \%$ of the peak demand during the off-operation hours and over the week-ends and holidays. The preceding discussion of the thermal accumulator as an element of the central utility plant system.

\section{Ownership Scenarios}

The cost of ownership model may be use to evaluate many possible fuel cell applications, The following five cases are provided to indicate the range of the cost of ownership model. The following data is a summary of the Ownership Model Output provided by the model.

Case 1: Owner : Individual Commercial Owner and User

Application Description: Class 1- Large Hotel with 7 day a week, 24 hour operations.

Maximum utilization of fuel cell peak capacity.

Electrical Demand:

Thermal Demand:

$200 \mathrm{~kW}$

Plant Description

Plant Capacity Output:

$850,000 \mathrm{Btu} / \mathrm{Hour}$

Plant Capital Cost:

Operating Costs:

$200 \mathrm{~kW}$

$\$ 497,970$

$\$ 105,275$

7Bibliograpphy reference No. 14 
Benefits:

Financial Performance

Present Value of Investment:

Present value of Fuel Cell only:

$\$ 933,255$

$\$ 749,181$

Present Value of Replacement Electricity:

$(\$ 1,915,995)$

Case 2 : Owner -Individual Commercial Owner and User

Application Description: Class 1- Large Hotel with 7 day a week, 24 hour operations. Double peak demand.

Maximum utilization of fuel cell peak capacity.

Electrical Demand:

Thermal Demand:

Plant Description

Plant Capacity Output:

Plant Capital Cost:

Operating Costs:

Benefits:

Financial Performance

Present Value of Investment:

Present value of Fuel Cell only:

Present Value of Replacement Electricity:
$240 \mathrm{~kW}$

$660,000 \mathrm{Btu} / \mathrm{Hour}$

$240 \mathrm{~kW}$

$\$ 575,964$

$\$ 86,229$

$\$ 190,330$

$\$ 288,114$

$\$ 199,471$

$(\$ 1,355,933)$

Case 3: Owner - Individual Industrial Owner and User

Application Description: Class 3- Large Office Building with 6 day a week, with single 10 hour demand peak operations.

Maximum utilization of fuel cell peak capacity.

Electrical Demand:

Thermal Demand:

$524 \mathrm{~kW}$

$660,000 \mathrm{Btu} / \mathrm{Hour}$

Plant Description

Plant Capacity Output:

$524 \mathrm{~kW}$

Plant Capital Cost:

$\$ 1,257,521$

Operating Costs:

$\$ 166,058$

Benefits:

$\$ 301,987$ 
Financial Performance

Present Value of Investment:

$(\$ 129,267)$

Present value of Fuel Cell only:

$(\$ 174,8030$

Present Value of Replacement Electricity:

$(\$ 2,191,508)$

Case 4: Owner : Individual Owner and User

Application Description: Class 2- Large Industrial Facility, 7 day a week, 2 eight hour shift operations.

Maximum utilization of fuel cell peak capacity.

Electrical Demand:

Thermal Demand:

$580 \mathrm{~kW}$

203,000 Btu/Hour

Plant Description

Plant Capacity Output:

$580 \mathrm{~kW}$

Plant Capital Cost:

Operating Costs:

Benefits:

$\$ 1,391,912$

$\$ 220,104$

$\$ 396,534$

Financial Performance

Present Value of Investment:

Present value of Fuel Cell only:

$\$ 71,029$

$\$ 70,695$

Present Value of Replacement Electricity:

$(\$ 2,883,923)$

Case 5: Owner -Individual Commercial Owner and User

Application Description: Class 1- Large Hotel with 7 day a week, 24 hour operations.

Maximum utilization of fuel cell peak capacity.

Electrical Demand:

$2200 \mathrm{~kW}$

Thermal Demand:

$6,600,000$ Btu/Hour

Plant Description

Plant Capacity Output:

$2200 \mathrm{~kW}$

Plant Capital Cost:

$\$ 5,279,667$

Operating Costs:

$\$ 691,321$

Benefits:

$\$ 1,125,455$ 
Financial Performance

Present Value of Investment:

$(\$ 1,676,204)$

Present value of Fuel Cell only:

$(\$ 2,561,961)$

Present Value of Replacement Electricity:

(\$7,216,307) 


\section{BIBLIOGRAPHY}

1. ASHRAE, ASHRAE Handbook: Equipment 1988, Chapters 13, 23.

2. ASHRAE, ASHRAE Handbook: Systems 1984, Chapters 5,13.

3. GRI, Comparative Market and Economic Analyses: On site Fuel Cells, Final Report Vol. I, Dec. 1980, GRI-79/0095.

4. GRI, Comparative Market and Economic Analyses: On Site Fuel Cells, Final Report Vol. II - Appendices, Dec. 1980, GRI-79/0095.2.

5. GRI, 481 Prototypical Commercial Buildings for Twenty Urban Market Areas, Dec. 1990, GRI-90/0326

6. International Fuel Cells, The PC-25 Fuel Cell Power Plant, Aug. 1986.

7. R. S. Means Co. Inc., Means Facilities Cost Data 1993 Construction Consultants \& Publishers, Kingston, MA 1993

8. R. S. Means Co. Inc., Means Mechanical Cost Data 1992, Construction Consultants \& Publishers, Kingston, MA 1992.

9. Stamper \& Koral, Handbook of air-conditioning, Heating and Ventilating, Chapters 7.

10. GRI, Commercial Buildings Cogeneration Market: Characterization and Trends, April $1990 \mathrm{GRI}-89 / 0246$

11. GRI, 40-kW On site Fuel Cell Field Test Summary Utilities Activities Report - Final Report, July 1987, GRI-87/0205

13. The Trane Company, Commercial Systems Group Product Information Literature, Single Stage Absorption Cold Generator: 101 to 1660 Tons, La Crosse, WI, March 1989

14. Manes Associates, Combined Use Energy Survey, Published under contract DE-FC92-MC29227, as part of An Economic Feasibility Analysis of Distributed Electric Power Generation Based Upon the Natural Gas-Fired Fuel Cell, November 1992 
15. Manes Associates, A Central Plant Utility Model, Published under contract DE-FC92-MC29227 as part of An Economic Feasibility Analysis of Distributed Electric Power Generation Based Upon the Natural Gas-Fired Fuel Cell, November 1992

16. Energy Information Administration, U.S. Department of Energy, Annual Energy Ouilook 1993 DOE/EIA-0383 (93), January 1993

17. California Public Utilities Commission, Administrative Law Judges Decision No. 1.89-07-004, filed July 6, 1989

18. California Public Utilities Commission, Administrative Law Judges Decision No. 91-06-022, filed June 5, 1991

19. Pace University Center for Environmental Legal Studies, Environmental Costs of Electricity, Prepared for the New York State Energy Research and Development Authority and the United States Department of Energy, 1991 Oceana Publications, Inc. N.Y., N.Y. 


\section{GLOSSARY OF TERMS}

Absorption chiller

The absorption chiller is a refrigeration system that uses the evaporation and condensation of a lithium bromide salt and water solution to produce refrigeration. The evaporation is driven by thermal energy as steam or hot water. The temperature of the refrigerant (gas) is reduced by transfer to a wet cooling tower. The cool gas is returned to the point of refrigeration where the condensation absorbs the heat. The hot liquid is returned to the evaporator and the process is repeated. The system has been in commercial use for a number of years. It is marketed by Trane and Rheem.

Centrifugal chiller

The centrifugal chiller is a freon vapor-cycle refrigeration system that uses a mechanically driven centrifugal compressor. These systems are common in large industrial applications where the required system capacity is from 10 to 200 tons.

Fan-coil heat exchanger

The fan-coil heat exchanger is used on hydronic space conditioning systems. They are installed at the point-of-use provide heated or chilled air. Hot and cold fluid are supplied to a temperature controlled valve that admits the correct temperature fluid to the heat exchanger coil. The heat exchanger fan circulates room air across the heat exchanger coil.

Hydronic

A hydronic space conditioning system provides heating or cooling by circulating a heat transfer fluid (usually treated water) from a central heating or chilling source to the point of use.

Potable

A potable water source delivers water that is suitable for drinking.

Turn-down performance

Turn-down performance is the performance of a machine that is operating at less than rated capacity. It is generally stated as the ratio of the performance at reduced load to the performance at full or design load. The term is commonly used to express the performance or efficiency of turbines or electrical generators. 
Appendix D

\section{APPENDIX 1 \\ PERFORMANCE MODEL EQUATIONS}

FUEL CONSUMPTION AS A FUNCTION OF POWER OUTPUT

\begin{tabular}{|c|c|c|c|c|c|c|c|c|}
\hline Power, kW & & inches & Fuel & Calc. & & & & \\
\hline$x$ & $x \wedge 2$ & Y & SCFH & SCFH & DMLS $x$ & $x \wedge 2$ & DMLS Y & $\begin{array}{l}\text { CALC } \\
\text { DMLSY }\end{array}$ \\
\hline 0 & 0 & 0.215 & 173.39 & 166.28 & 0.0000 & 0.0000 & 0.0903 & 0.086561 \\
\hline 25 & 625 & 0.405 & 326.61 & 326.34 & 0.1250 & 0.0156 & 0.1700 & 0.169884 \\
\hline 50 & 2500 & 0.62 & 500.00 & 504.05 & 0.2500 & 0.0625 & 0.2603 & 0.262394 \\
\hline 75 & 5625 & 0.85 & 685.48 & 699.41 & 0.3750 & 0.1406 & 0.3568 & 0.364091 \\
\hline 100 & 10000 & 1.125 & 907.26 & 912.41 & 0.5000 & 0.2500 & 0.4723 & 0.474975 \\
\hline 125 & 15625 & 1.425 & 1149.19 & 1143.06 & 0.6250 & 0.3906 & 0.5982 & 0.595045 \\
\hline 150 & 22500 & 1.735 & 1399.19 & 1391.36 & 0.7500 & 0.5625 & 0.7284 & 0.724303 \\
\hline 175 & 30625 & 2.082 & 1679.03 & 1657.31 & 0.8750 & 0.7656 & 0.8741 & 0.862747 \\
\hline 200 & 40000 & 2.382 & 1920.97 & 1940.90 & 1.0000 & 1.0000 & 1.0000 & 1.010378 \\
\hline
\end{tabular}

USEFUL THERMAL ENERGY AS A FUNCTION OF ELECTRIC LOAD

\begin{tabular}{|c|c|c|c|c|c|c|c|c|}
\hline$X, K W$ & $x \wedge 2$ & Y.in. & $\begin{array}{c}\text { Y. } \\
\text { Byu/hr }\end{array}$ & YCalc. & $\begin{array}{c}X \\
\text { DMLS }\end{array}$ & $x \wedge 2$ & $\begin{array}{c}\text { Y, } \\
\text { DMLS }\end{array}$ & $\begin{array}{l}\text { Calc Y } \\
\text { DMLS }\end{array}$ \\
\hline 0 & 0 & 0.049 & 14010 & 9437 & 0.0000 & 0.0000 & 0.0169 & 0.011362 \\
\hline 25 & 625 & 0.26 & 74339 & 78137 & 0.1250 & 0.0156 & 0.0895 & 0.094074 \\
\hline 50 & 2500 & 0.545 & 155826 & 156861 & 0.2500 & 0.0625 & 0.1876 & 0.18885 \\
\hline 75 & 5625 & 0.855 & 244460 & 245609 & 0.3750 & 0.1406 & 0.2943 & 0.295703 \\
\hline 100 & 1000 & 1.193 & 341101 & 344381 & 0.5000 & 0.2 & 0.4107 & 0.41462 \\
\hline 125 & 15625 & 1.575 & 450322 & 453176 & 0.6250 & 0.3906 & 0.5422 & 0.545606 \\
\hline 150 & 22500 & 2.025 & 578985 & 571996 & 0.7500 & 0.5625 & 0.6971 & 0.688659 \\
\hline 175 & 30625 & 2.485 & 710508 & & 0.8750 & & 0.8554 & 0.843781 \\
\hline 200 & 40000 & 2.905 & 830593 & 839706 & 1.0000 & 1.00000 & 1.0000 & 1.010972 \\
\hline
\end{tabular}


Calculated coefficients of thermal energy consumption

$$
A X^{2} \quad B X
$$

C

Calculated coefficients of fuel

$B X$

$A X^{2}$

BX

C

$$
\begin{array}{rrrr}
0.3862 & 0.6134 & 0.0114 & \\
0.030101 & 0.031284 & 0.006709 & \\
0.999569 & 0.008254 & \# \mathrm{~N} / \mathrm{A} & \\
0.2940 & 0.6298 & 0.0866 \\
0.027463 & 0.028543 & 0.006121 \\
0.999578 & 0.007531 & \# \mathrm{~N} / \mathrm{A}
\end{array}
$$




\section{APPENDIX 2}

\section{OWNERSHIP MODEL EQUATIONS}

\section{Select User Class}

Choose from among three pre defined user classes and set the model electrical and thermal demand equal to the selected class.

User_Class $=$ Class $(i)\left[\begin{array}{l}i=1 \\ i=3\end{array}\right)$

Electric_Demand $=$ Class $(i)$ Electric $\left[\begin{array}{l}t=1 \\ t=24\end{array}\right)$

Thermal_Demand $=$ Class $(i)$ Thermal $\left[\begin{array}{l}t=1 \\ t=24\end{array}\right)$

2. In applications where the demand profile does not match the predetermined "user classes" the model user can input the electrical demand and the thermal demand as 24 data pair in $\mathrm{kW}$ and thousands of Btu per hour. The user chooses class $=4$ and is presented with a data input screen. The program converts the demand data into a demand profile as a ratio of demand / peak demand. The class 4 profile is then treated the same as class 1, 2 or 3 .

Electric_Capacity $\equiv \operatorname{Max}($ Electric_Demand $)$

2. For all other cases, set the fuel cell capacity equal to user input peak electrical demand

Electric_Capacity $\equiv$ Peak_Electrical

3. Compute daily fuel cell electrical production

Daily_Power $=$ Peak_Electrical $\times \sum_{t=1}^{24}[$ Electric_Demand $(t)]$

4. The natural gas consumption of the fuel cell as a fraction of the gas consumption at the design capacity is computed from as a quadratic function of the form $Y=a X^{2}+b X+c$. The independent variable is the ratio of the electric demand to the peak demand. The coefficients of $X, \mathbf{a}_{g}, \mathbf{b}_{g}$ and $\mathbf{c}_{g}$ were developed by multiple linear regression as described in Appendix 1, from empirical data 
was taken from reference 6 . The fraction of design point gas consumption is converted to a dimensional value of standard cubic feet per hour by the constant Gas rate, SCFH / $\mathrm{kW}$.

Daily_GasConsumed $=$ Peak_Electrical $\times$ Gasrate $\times$

$\sum_{i=1}^{24}\left[a_{g} \times(\text { Electric_Demand }(t))^{2}+b_{g} \times(\right.$ Electric_Demand $\left.(t))+c_{g}\right]$

5. Equations for the daily production of thermal energy are similar to those for gas consumption. They differ only by the coefficients for the quadratic expression $\mathbf{a}_{\mathrm{h}}, \mathbf{b}_{\mathrm{h}}$ and $\mathbf{c}_{\mathrm{h}}$ and the ratio of the production of thermal energy to the production of electrical energy, Hrate. Daily thermal production is expressed in Btu per day

Daily_Thermal $=$ Peak_Electrical $\times$ Hrate $\times$

$\sum_{t=1}^{24}\left[a_{h} \times(\text { Electric_Demand }(t))^{2}+b_{h} \times(\right.$ Electric_Demand $\left.(t))+c_{h}\right]$

6. The daily gas consumption and thermal energy produced are converted into annual rates by multiplying the daily rate times the summer days plus the daily rate times the winter days. The distinction between winter and summer is maintained to apply the appropriate gas purchase and electric power sales rates in the Operations model. The units of power produced is $\mathrm{kW}$ hr. Gas consumed is expressed in SCF

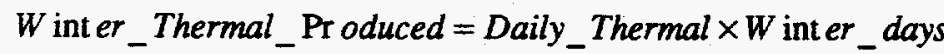

Summer_Thermal_Produced $=$ Daily_Thermal $\times$ Summer_Days

Annual_Thermal_Produced $=$ Summer_Thermal_Produced $+W$ int $e r_{-}$Thermal_Produced

$W$ inter_Gas_Consumed $=$ Daily_Gas_Consumed $\times W$ int $e r_{-}$Days

Summer_Gas_Consumed $=$ Daily_Gas_Consumed $\times$ Summer_Days

Annual_Gas_Consumed $=W$ int $r_{-}$Gas_Consumed + Summer_Gas_Consumed

7. Compute the heating and air conditioning thermal demand. The thermal energy required for heating is computed from the input space conditioning capacity, assumed duty cycle and the number of winter days. The assumed duty cycle is the dimensionless ratio of hours of operation at full capacity to the number of hours per day. The output is in Btu per year.

The air conditioning thermal energy requirement is computed from the input capacity, Air_Conditioning in tons, converted to Btu's times the assumed duty cycle times the number of cooling days in the summer divided by the coefficient of performance of the absorption chiller, COP. The output is in Btu per year. 
Heating $=$ Space_Heat $\times 12 \mathrm{hr} /$ Day $\times W$ int $e r$

Cooling $=$ Air_Conditioning $\times$ Btu_perTon_Hr $\times 12 /$ Day $\times$ Summer $/$ COP

8. Compute the thermal energy production excess (deficit) to size the backup boiler and compute the boiler fuel requirements. The boiler is sized for the larger of comfort heating backup or air conditioning chiller input temperature booster.

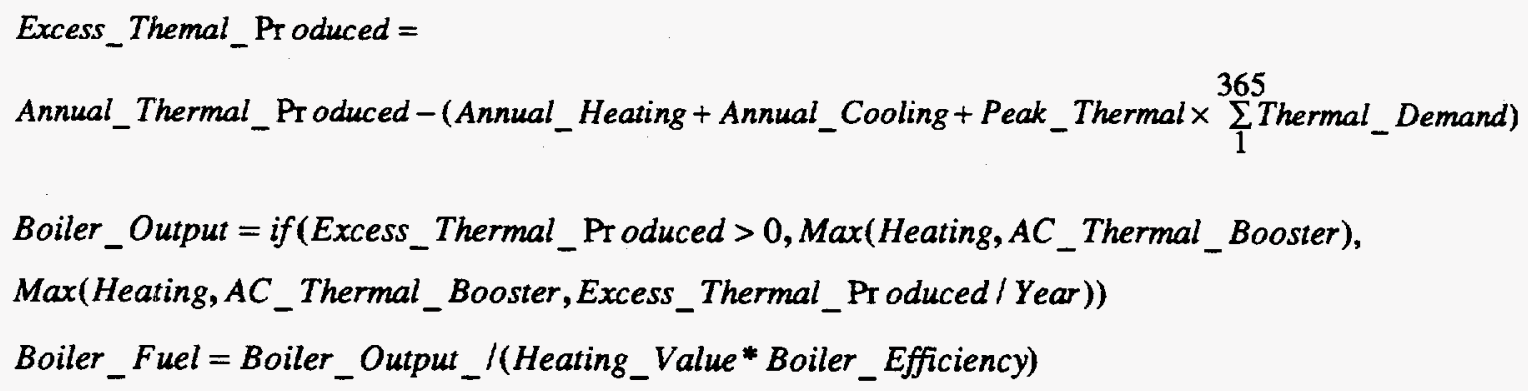

Where the boiler output is expressed in Btu per hour and the boiler fuel required is SCFH.

9. Compute the required storage capacity of the thermal accumulator tank

$$
\begin{aligned}
& \text { Mean_Thermal_Demand } \left.=\text { Peak_Thermal } \times \sum_{1}^{365} \text { Thermal_Demand }\right) / 24 \\
& \text { Volume }=\left[\Sigma_{1}^{24} \text { if }\left\{\left(\text { Peak_Thermal } \times \sum_{1}^{365} \text { Thermal_Demand }\right)\right)-\text { Mean_Thermal_Demand }>0\right. \text {, } \\
& \text { (Peak_Thermal } \times \sum_{1}^{24} \text { Thermal_Demand)) -Mean_Thermal_Demand,0)\}]/(Delta_T*lb_per_gallon) }
\end{aligned}
$$

Where Delta_ $T$ is the increase in the stored water temperature from room temperature to fuel cell output temperature. Volume is expressed in gallons.

10. Compute the cooling tower capacity. Fuel cell cooling is required in the event of failure of the heat transfer equipment. The absorption cooling equipment must have wet tower cooling to reject the heat removed from the application plus the thermal energy added to drive the process. It is assumed that only the larger demand will be designed for. Space cooling would be cut back to tower capacity in the event of a failure.

$$
\begin{aligned}
& \text { Cooling_Tower_Capacity }= \\
& {\left[\text { Max }(\text { Air_Conditioning* }(1+\text { COP })), \text { Hrate }^{*} \text { Peak_Electricall Btu_perTon_hr }\right]}
\end{aligned}
$$

Where cooling tower capacity is expresses in refrigeration tons per $\mathrm{hr}$. 